IZA DP No. 7190

Partisan Tax Policy and Income Inequality in the U.S., 1979-2007

Olivier Bargain Mathias Dolls Herwig Immervoll Dirk Neumann

January 2013
Andreas Peichl

Nico Pestel

Sebastian Siegloch 


\title{
Partisan Tax Policy and Income Inequality in the U.S., 1979-2007
}

\author{
Olivier Bargain \\ Aix-Marseille School of Economics, CNRS \\ $\&$ EHESS, IZA and CEPS-INSTEAD
}

Mathias Dolls

IZA and University of Cologne

Herwig Immervoll

World Bank, OECD, ISER and IZA

\author{
Dirk Neumann \\ IZA and University of Cologne
}

\author{
Andreas Peichl \\ IZA, University of Cologne, \\ ISER and CESifo
}

Nico Pestel

IZA and University of Cologne

\section{Sebastian Siegloch \\ IZA and University of Cologne}

\author{
Discussion Paper No. 7190 \\ January 2013
}

\author{
IZA \\ P.O. Box 7240 \\ 53072 Bonn \\ Germany \\ Phone: $+49-228-3894-0$ \\ Fax: +49-228-3894-180 \\ E-mail: iza@iza.org
}

Any opinions expressed here are those of the author(s) and not those of IZA. Research published in this series may include views on policy, but the institute itself takes no institutional policy positions. The IZA research network is committed to the IZA Guiding Principles of Research Integrity.

The Institute for the Study of Labor (IZA) in Bonn is a local and virtual international research center and a place of communication between science, politics and business. IZA is an independent nonprofit organization supported by Deutsche Post Foundation. The center is associated with the University of Bonn and offers a stimulating research environment through its international network, workshops and conferences, data service, project support, research visits and doctoral program. IZA engages in (i) original and internationally competitive research in all fields of labor economics, (ii) development of policy concepts, and (iii) dissemination of research results and concepts to the interested public.

IZA Discussion Papers often represent preliminary work and are circulated to encourage discussion. Citation of such a paper should account for its provisional character. A revised version may be available directly from the author. 


\begin{abstract}
Partisan Tax Policy and Income Inequality in the U.S., 1979-2007

We assess the effects of U.S. tax policy reforms on inequality by applying a new decomposition method that allows us to disentangle the direct policy effect from the effect of changing market incomes. Over the whole period 1979-2007 the cumulative tax policy effect aggravated income inequality by increasing the income share of the top $20 \%$ in contrast to the middle class' share. The tax policy effect accounts for up to $29 \%$ of the total change in inequality; its contribution increases up to $41 \%$ if we take into account behavioral responses. Using our unique policy effect measure and variation in tax policies across U.S. states and time, we also identify the redistributive intention of policymakers. The estimated effect of partisan politics on the U.S. income distribution is statistically significant and economically important. Republican policymakers increased inequality especially at the top whereas Democrats increased the income share of the bottom $80 \%$ of the distribution.
\end{abstract}

JEL Classification: H23, H31, H53, P16

Keywords: tax policy, inequality, redistribution, partisan politics, political economy

Corresponding author:

Andreas Peichl

IZA

P.O. Box 7240

53072 Bonn

Germany

E-mail: peichl@iza.org

\footnotetext{
* This paper uses TAXSIM V9. TAXSIM is continually being improved and updated and the results presented here represent the best available at the time of writing. Our version of TAXSIM is based on IRS SOI tax return data. We would like to thank Daniel Feenberg for granting us access to NBER's TAXSIM and helping us with our simulations. We are grateful to Alberto Alesina, James Alm, Felix Bierbrauer, Denvil Duncan, Clemens Fuest, Carl Klarner, Wojciech Kopczuk, Jeff Larrimore, Erzo F.P. Luttmer, Jim Poterba, Ronald L. Oaxaca, Andrew Oswald, Emmanuel Saez, James Sullivan, Tim Smeeding, as well as seminar and conference participants in Bonn (IZA), Buch (ESSLE), Cambridge (NBER SI), Canazei (IT8), Chicago (SOLE), Dublin (IMA), Göttingen (VfS) and Providence (NTA) for helpful comments and suggestions. Peichl is grateful for financial support by Deutsche Forschungsgemeinschaft (PE1675). Any errors as well as the views presented in this paper are the responsibility of the authors alone. In particular, the views do not represent the official positions of organizations to which the authors are affiliated.
} 


\section{Introduction}

Over the past decades incomes have become more unequally distributed in most OECD countries and especially in the United States (OECD 2011). In particular, the increase of the top 1\%'s income share has received considerable attention (e.g., Piketty and Saez 2003) resulting in numerous calls for higher taxes on the rich (e.g., Diamond and Saez 2011, Piketty et al. 2011). Yet, very little is known about the actual impact of tax policy changes on inequality. The reason is that the usual evaluation approach - comparing income inequality measures before and after taxes (see, e.g., Gottschalk and Smeeding 1997 or Heathcote et al. 2010) - is not able to isolate the pure policy effect because tax burdens are determined by both tax policy and pre-tax income distribution. For instance, a given progressive income tax schedule redistributes more when the distribution of taxable incomes becomes more dispersed, and not at all if everybody earns the same (Musgrave and Thin 1948, Dardanoni and Lambert 2002). Hence, it is unclear how much of an observed change in tax liabilities (and resulting inequality) is due to policy reforms and what part is due to other factors, notably the change in the underlying pre-tax income distribution.

This paper is the first to isolate and quantify the pure tax policy effect on inequality in the U.S. for the period 1979-2007. Our paper can be seen as a natural follow-up of the study by Piketty and Saez (2007) who analyze changes in the progressivity of the federal income tax over time but cannot disentangle policy changes from other factors. We also use tax return micro data from the Statistics of Income (SOI) division of the Internal Revenue Service (IRS) ${ }^{1}$ and the NBER's TAXSIM calculator for our analysis which proceeds in two steps. First, we perform a series of detailed counterfactual simulations that show how the post-tax income distribution would have looked like if either tax policy (federal and state level income and payroll taxes) or the distribution of pre-tax incomes had remained unchanged between two given years. This allows us to quantify the direct tax policy effect on inequality and to provide novel empirical evidence on the question to what extent the increase in inequality, in particular the surge in top income shares, is market driven or caused by major U.S. tax reforms during the past three decades. ${ }^{2}$ In addition, we extend the baseline decomposition by using estimates for the elasticity of taxable income (ETI, see Saez et al. 2012 for a survey)

\footnotetext{
${ }^{1}$ Note that as a robustness check, we perform the decomposition analysis on the Current Population Survey (CPS) and show that results are in line with those based on tax return data. This comparison of how the policy effect on inequality differs between IRS SOI tax return and CPS data complements the analysis by Burkhauser et al. (2012a) who reconcile estimates on top income shares between these two data sources.

${ }^{2}$ Our approach formalizes analyses of policy effects, as performed for instance by Clark and Leicester (2004) for the United Kingdom. See also Bargain and Callan (2010) for France and Ireland. A related concept for the comparison of tax regimes with respect to progressivity - the transplant-andcompare procedure (Dardanoni and Lambert 2002) - is applied by Lambert and Thoresen (2009) for Norway. They isolate the tax policy effect by comparing pre-tax income distributions which have been adjusted to a common base.
} 
in order to account for indirect policy effects due to behavioral responses. Second, we use the derived policy effect to uncover policymakers' redistributive intentions. Thus, we contribute to the literature on the political economy of redistribution (e.g. Bartels 2008) by estimating the partisan tax policy effect. In contrast to conventional measures, such as pre- or post-tax inequality which are affected by other factors beyond the control of policymakers, our decomposition method enables us to investigate the 'intended' impact of partisan politics on the income distribution. For identification, we exploit the substantial heterogeneity in tax policies across U.S. states and over time.

Our main findings are as follows. The baseline decomposition shows that the size of the policy effect corresponds to $11-29 \%$ of the total change in income shares of different income groups. The impact is largest for taxpayers in the 95th to 99th percentile of the income distribution, but smallest for those in the top 1\%. This shows that tax policy had a non-negligible effect on changes in inequality, but explains only a small fraction of the sharp increase of the top 1\%'s income share, where other forces played a much more important role. Extending the baseline decomposition and accounting for indirect policy effects (i.e. behavioral responses) does not affect our results qualitatively, but yields a larger overall policy effect on inequality (up to $41 \%$ of the total change). We also find that reforms in the 1980s and early 2000s exacerbated trends of growing inequality, those in the early 1990s benefited low-income taxpayers. The cumulative policy effect over the entire period contributed to the increasing income share of taxpayers in the top quintile (and especially the top decile) at the cost of middle class taxpayers. Hence, without any tax policy changes, observed inequality would be lower nowadays. In the second part of our analysis, we show that partisan tax policy effects are statistically significant and economically important. Tax reforms of Republican policymakers benefited the top quintile at the cost of the bottom $80 \%$, whereas the opposite is true for Democrats. The partisan effect of controlling either the legislative or the executive branch of state governments accounts for $12-42 \%$ (depending on the inequality measure) of the total change in post-tax inequality.

The rest of the paper is organized as follows. Section 2 reviews the related U.S. income inequality literature. The decomposition analysis, the data and income concepts are described in section 3. Decomposition results are presented in section 4. Section 5 analyzes how the political cycle in the U.S. has affected inequality. Section 6 concludes.

\section{Related literature}

Rising income inequality in the U.S. has stimulated a large body of research examining the underlying driving factors. In this literature, several strands have emerged which focus on different types of inequality. While the focus of this paper is on redistribution and the impact of tax policy on trends in post-tax income inequality, this cannot be 
comprehensively assessed without taking into account trends in pre-tax inequality.

The existing evidence on pre-tax inequality in the U.S. points to a widening gap, in particular at the top of the distribution. In a seminal contribution, Piketty and Saez (2003) (updated 2012) build a series of pre-tax income shares based on tax return data from the IRS. They find that inequality grew relatively smoothly in the time period considered here. Further studies relying on IRS tax return data are, among others, Slemrod (1992), Feenberg and Poterba (1993), DeBacker et al. (2012) and Bakija et al. (2012) who, in particular, look at top incomes. Similar trends are found in analyses using CPS data. ${ }^{3}$ A general conclusion from these studies is that total income inequality, i.e. inequality in pre-tax, post-transfer income rose sharply in the 1980 s, and that this growth continued at a reduced pace in the 1990s and early 2000s. Burkhauser et al. (2012a) seek to reconcile findings from IRS SOI and CPS data. They use internal CPS data which are - compared with public-use CPS - much less affected by topcoding (although a number of other measurement and conceptual differences remain) and apply similar income definitions as Piketty and Saez (2003) do, namely pre-transfer, tax-unit income. They conclude that the rise in inequality from 1993 onwards is mainly due to gains made by the top $1 \%$ of the income distribution.

We contribute to the literature which examines the impact of tax policy on posttax income inequality. By extracting the direct policy effect through counterfactual simulations, we complement analyses conducted by Piketty and Saez (2007) or the Congressional Budget Office (2010). In these studies, shares of post-tax income and average federal tax rates are calculated for all income groups and similar time periods. However, the estimates do not allow to isolate the direct policy effect since they reflect both legislative changes as well as other factors which influence tax rates. Some studies have conducted so-called "what if" calculations (Poterba 2007) but to the best of our knowledge, none of these papers have sought to identify a policy effect on a year-byyear basis over a long time period. We are aware of two contributions which explicitly consider - via counterfactual simulations - the impact of tax policy on the post-tax income distribution. In an analysis of policy changes during the 1980s, Gramlich et al. (1993) apply tax and transfer policies of 1980 and 1985 to the pre-tax income distribution of 1990 . They report that $16 \%$ of the increase in the Gini coefficient from 1980 to 1990 are due to changes in taxes and transfers. More recently, Poterba (2007) conducts conceptually similar policy swaps by applying 2004 effective tax rates to the 2000 pre-tax income distribution and vice versa and examines the resulting effects on the share of post-tax (but before payroll tax) income accruing to various income groups. A key finding from his analysis is that the impact of changes in the pre-tax

\footnotetext{
${ }^{3}$ See e.g. Gottschalk and Danziger (2005), Heathcote et al. (2010), Burkhauser et al. (2011) and Burkhauser et al. (2012b). Differences between these studies exist with regard to the definition of the income unit (family vs. household), sample selection (full population vs. working-age population) and whether or not topcoding in the public-use CPS is accounted for.
} 
income distribution is approximately four times as large as the policy effect of changes in effective tax rates. ${ }^{4}$

The second strand of literature to which our study directly relates examines the relationship between partisan politics and redistribution. Here, it is important to differentiate between studies which seek to identify partisan effects either on social spending and tax levels or on direct measures of inequality such as pre- and post-tax inequality. Traditionally, some measures of social spending or tax levels are used to evaluate the generosity of government policies (McCarty and Pontusson 2009). Pettersson-Lidbom (2008) finds spending and tax levels to be 2-3\% higher under leftist governments in a panel of Swedish local governments. Reed (2006) estimates for a 40-year panel of U.S. states that a Democratic state legislature is associated with a 3-5\% higher state tax burden. Scheve and Stasavage (2009) analyze the effect of partisanship on pre-tax inequality for a panel of 13 OECD countries spanning the 20th century and do not find a statistically significant effect - except for the income share of the top $1 \%$ which is very small, however. Bartels (2008) compares real pre-tax income growth of affluent, middle-class and working poor families for the period 1948-2005 showing that overall pre-tax income growth was largest for high-income families, but only in periods with Republican Presidents. He finds similar patterns of post-tax income growth for the period 1980-2003. Leigh (2008b) estimates for a panel of U.S. states from 1941-2002 the effect of gubernatorial partisanship on various economic outcomes including pre- and post-tax inequality and finds mostly insignificant results. Our approach differs from all these studies since our policy effect, which summarizes the impact of multi-dimensional tax policy reforms, is unaffacted by changes in pre-tax inequality and, hence, can be seen as a direct measure of the partisan effect on post-tax inequality.

\section{Methodology}

\subsection{Decomposition}

In order to decompose inequality changes into the effect of tax policy and other factors, we follow and extend the approach suggested by Bargain and Callan (2010). Consider a data matrix $y$ containing information on individuals' pre-tax income from different sources as well as various individual and household characteristics which are relevant for the calculation of income and payroll taxes. The tax function $d$ represents the rules

\footnotetext{
${ }^{4}$ Further studies examining the degree of redistribution of the U.S. income tax system by means of policy swaps are Kasten et al. (1994), Mitrusi and Poterba (2000), Alm et al. (2005), Leigh (2008a) and Meyer (2010). However, these studies do not quantify how much of an observed change in post-tax income inequality is due to policy changes. Instead, the focus of these contributions is on the changing importance of income and payroll taxes over time (Mitrusi and Poterba 2000), on the progressivity of the income tax (Kasten et al. 1994 and Alm et al. 2005), the redistributiveness of state taxes (Leigh 2008a) and the distributional effect of the EITC reform enacted through the American Recovery and Reinvestment Act of 2009 (Meyer 2010).
} 
and structure of the tax system (e.g., marginal tax and contribution rates) while vector $p$ accounts for all the monetary parameters (e.g., tax brackets). The distribution of post-tax income is represented by $d_{i}\left(p^{j}, y^{l}\right)$ for tax rules of year $i$, tax parameters of year $j$ and nominal incomes (and characteristics) of year $l$. For counterfactual simulations, it is necessary to nominally adjust income levels by an uprating factor $\alpha$ accounting for nominal changes (e.g. inflation) between base and end year.

For the decomposition, two different approaches are possible: it can be conducted either on base year or on end year incomes while applying tax policy of the respective other year. First, the counterfactual situation $d_{t+1}\left(p^{t+1}, \alpha^{t+1} y^{t}\right)$ represents post-tax incomes obtained by applying tax rules and parameters of year $t+1$ on year $t$ data nominally adjusted to year $t+1$. Here the policy of end year $t+1$ is applied while holding the pre-tax incomes of year $t$ constant. Second, we can apply the initial policy from year $t$ to the pre-tax income distribution in $t+1$. For this, we need to construct a counterfactual $d_{t}\left(p^{t}, \frac{y^{t+1}}{\alpha^{t+1}}\right)$ where pre-tax incomes are adjusted with the same factor $\alpha^{t+1}$ used to scale up the distribution of pre-tax income between period $t$ and $t+1 .^{5}$ As further explained below, policy changes usually combine changes in policy structure $d$ and changes in parameters $p$ (the 'uprating policy').

In the empirical part, we are interested in distributional measures $M$, computed as a function $M\left[d_{i}\left(p^{j}, y^{l}\right)\right]$ of the simulated distribution of post-tax income. The advantage of the present approach is that we can use any measure and not only those with specific properties (i.e., decomposable inequality indices). More generally, it is possible to decompose any scalar $M$ such as inequality indices, (top) income shares, average and marginal tax rates or measures of redistribution. Characterize the total change $\Delta M$ in measure $M$ between initial and final period as

$$
\Delta M=M\left[d_{t+1}\left(p^{t+1}, y^{t+1}\right)\right]-M\left[d_{t}\left(p^{t}, y^{t}\right)\right]
$$

and notice that the last term can also be written $M\left[d_{t}\left(\alpha^{t+1} p^{t}, \alpha^{t+1} y^{t}\right)\right]$ since function $d$ is linearly homogenous in $p$ and $y .{ }^{6}$ Then, the total change between periods $t$ and $t+1$ can be decomposed into a change in tax policy and a change in the pre-tax income distribution. We refer to the last change as the 'other effect'. The 'policy effect' can be assessed on end period data $y^{t+1}$, and in this case, the other effect is assessed on the base period tax system, yielding decomposition I:

\footnotetext{
${ }^{5}$ A measure $d_{t}\left(p^{t}, y^{t+1}\right)$ would not be consistent since base-period parameters would be artificially applied to end-period income levels. For instance, previous tax band thresholds would be applied to new and possibly higher income levels, thereby generating artificial 'fiscal drag' or 'bracket creep' (Saez 2003).

${ }^{6}$ Converting tax parameters and income from dollars into euros does not change the relative location of households in the distribution of post-tax income.
} 


$$
\begin{aligned}
\Delta M= & \underbrace{M\left[d_{t+1}\left(p^{t+1}, y^{t+1}\right)\right]-M\left[d_{t}\left(p^{t}, \frac{y^{t+1}}{\alpha^{t+1}}\right)\right]}_{\text {policy effect I }} \\
& +\underbrace{M\left[d_{t}\left(p^{t}, \frac{y^{t+1}}{\alpha^{t+1}}\right)\right]-M\left[d_{t}\left(p^{t}, y^{t}\right)\right]}_{\text {other effect I }}
\end{aligned}
$$

In this case, base period tax parameters are applied to end period data $y^{t+1}$ after nominal adjustment, i.e. $\frac{y^{t+1}}{\alpha^{t+1}}$. Symmetrically, the decomposition can be written as a policy effect assessed on base year data followed by a change in the underlying data conditional on the new policy. Decomposition II can thus be written as:

$$
\begin{aligned}
\Delta M= & \underbrace{M\left[d_{t+1}\left(p^{t+1}, y^{t+1}\right)\right]-M\left[d_{t+1}\left(p^{t+1}, \alpha^{t+1} y^{t}\right)\right]}_{\text {olicy effect II }} \\
& +\underbrace{M\left[d_{t+1}\left(p^{t+1}, \alpha^{t+1} y^{t}\right)\right]-M\left[d_{t}\left(p^{t}, y^{t}\right)\right]}_{\text {other effect II }} .
\end{aligned}
$$

Here, the end period tax system is evaluated on nominally adjusted base period data $\alpha^{t+1} y^{t}$.

As the decompositions are path-dependent, we suggest to simply average both policy and other effect over the decompositions I and II. This corresponds to Shorrocks (1999)'s reinterpretation of the Shapley value procedure. In the empirical part, we verify that results based on decompositions I and II usually do not differ (much). Exceptions indicate that significant (behavioral or conceptual) changes between base and end year occured, which were not captured in one year's data but present in the other years' data (such as income shifting between the corporate and private sector in anticipation of TRA86, as discussed below).

Notice that policy and other effect are affected by the choice of the uprating parameter $\alpha$. The way tax brackets are uprated by governments can have important implications for the income distribution in the long run. Usually there are three options: (1) no uprating, (2) uprating according to the level of price inflation, (3) uprating according to the level of earnings growth. With non-indexation of tax brackets in progressive systems, or price indexation when incomes rise faster than prices, the total number of tax payers (and the number of higher-rate taxpayers) increases. This phenomenon of bracket creep is likely to affect the final distribution of post-tax income. In our empirical application, we use changes in the consumer price index to adjust pre-tax incomes in the counterfactuals which is equivalent to an indexation of tax brackets. This reference situation is extensively used in policy analyses of tax reforms (cf., discussion in Clark and Leicester 2004). In a robustness check, we rely on a more 
conservative approach based on nominal wage growth, i.e., a distributionally-neutral scenario (Bargain and Callan 2010).

Our baseline decomposition accounts for direct effects of tax policy changes but does not consider behavioral responses to changes in tax policy. ${ }^{7}$ In section 4.3 , we further decompose the other effect into an indirect policy effect and a residual effect based on stylized estimates for the ETI.

\subsection{Data}

Several data sources have been used in studies on the impact of taxation on income inequality, in particular tax return data (e.g. Piketty and Saez 2007) and household surveys such as the CPS (e.g. Alm et al. 2005). It is well-known that there are advantages and disadvantages for both types of data (Poterba 2007). In brief, tax return data allow to precisely calculate top income shares, but do not contain information about non-filing households (typically at the bottom of the distribution) and lack certain (not tax-relevant) components of household income. In this study, we use large public use files of tax return data released. Annual cross-sectional micro-data are available from the SOI since 1960, but given that TAXSIM is able to simulate state level income taxes only from 1979 onwards, we start our analysis in $1979 .{ }^{8}$

We follow Piketty and Saez (2007) in terms of sample selection and include both filing and non-filing tax units so that income groups such as quintiles or top percentiles are based on the total population. ${ }^{9}$ Throughout this paper, we focus on pre- and post-tax income inequality. Tax units are ranked based on pre-tax incomes excluding capital gains as they are not a regular stream of income. For all subsequent calculations, capital gains are added back to pre- and post-tax incomes. Pre-tax income includes all sources of market income which are reported on tax returns, i.e. wages and salaries; bonuses and exercised stock-options; employer and private pensions; self-employment

\footnotetext{
${ }^{7}$ This approach is supported by Piketty and Saez (2007) who argue that given the controversy about behavioral responses to taxation "[...] considering the basic case with no behavioral response is a useful starting place" (p. 9).

${ }^{8}$ In a previous version of this paper, we have performed our calculations with data from IPUMSCPS (Integrated Public Use Microdata Series, Current Population Survey) which is a rich micro-data set of U.S. households and a primary data source for investigating income distribution trends. However, it does not contain information about itemized deductions and capital gains which are important in any analysis on top incomes. Further, for confidentiality reasons, the U.S. Census Bureau "top codes" all income sources, with differences in methods between some years. This can cause a downward bias of income inequality estimates (cf. Burkhauser et al. 2011). We compare the result from SOI to those obtained from CPS data in section 4.4.

${ }^{9}$ The total number of tax units in the US ranges from 97.5 million in 1979 to almost 150 million in 2007. Over the sample period, the share of tax units which file a tax return is roughly between 92-96\% (see online appendix of Piketty and Saez (2003), updated to 2010). Non-filing tax units are imputed as in Piketty and Saez (2007), i.e. under the assumption that they earn $20 \%$ of the average income of filing units. Because of this imputation, we usually do not report the decomposition results for the bottom quintile (P0-20) which mainly consists of non-filing tax units or households with low market incomes.
} 
income; business income; dividends, interest, and rents; and realized capital gains. Post-tax income is defined as pre-tax income minus the simulated components of the income tax system including federal and state level income taxes, employee social insurance contributions (payroll taxes), and tax credits (e.g. EITC). As is common in the literature, we thus assume that the burden of the taxes is borne by those who remit them and is not shifted elsewhere through adjustments in pre-tax wages and prices. Our measures of income do not include imputed corporate or federal estate and gift taxes. It is important to note that the policy effect, which is the focus of this study, is not affected by (omitting) these taxes given that we simulate them neither in the baseline nor in the counterfactual scenarios. ${ }^{10}$

In order to calculate income and payroll taxes, we use NBER's simulation model TAXSIM. ${ }^{11}$ The simulation approach allows us to conduct controlled experiments by changing the parameters of interest while holding everything else constant which avoids, by definition, endogeneity problems when identifying the effects of the policy reform under consideration (Bourguignon and Spadaro 2006). When assessing the isolated role of tax policy on income inequality (i.e. the policy effect), we are thus able to account for changes in federal and state level income taxes as well as payroll taxes and tax credits. Importantly, the policy effect is solely affected by changes in these taxes.

\subsection{U.S. tax history}

In this section, we briefly outline the major changes in the U.S. income tax system from 1979 until 2007 which are also summarized in an online appendix (Appendix A.3). We concentrate on large legislative changes which drive the tax policy effect. Reforms of interest are the Economic Recovery Tax Act of 1981 (ERTA81), the Tax Reform Act of 1986 (TRA86), the Omnibus Budget Reconciliation Act of 1990 and 1993 (OBRA90 and OBRA93), the Taxpayer Relief Act of 1997 (TRA97), the Economic Growth and Tax Relief Reconciliation Act of 2001 (EGTRRA01) and the Jobs and Growth Tax Relief Reconciliation Act of 2003 (JGTRRA03).

ERTA81 introduced the indexation of individual income tax parameters which became effective in 1985. Tax cuts were phased in over the years 1982-1984, with a reduction of top marginal tax rates from $70 \%$ to $50 \%$ in 1982 and of other tax rates by $23 \%$ in three annual steps. Further, the income threshold for the top rate substantially increased from $\$ 85,600$ in 1982 to $\$ 109,400$ (1983) and $\$ 162,400$ (1984) for married

\footnotetext{
${ }^{10}$ Some of the caveats discussed by Piketty and Saez (2007) apply to our study as well. In particular, we ignore the redistributive effect of government transfers and untaxed income such as in-kind benefits (except tax credits such as the EITC). Furthermore, our data are repeated cross-sections and we therefore abstract from any lifecycle perspective.

${ }^{11}$ For more information on TAXSIM see Feenberg and Coutts (1993) or visit http://www.nber.org/taxsim/. It contains all income and payroll tax rules which apply in a given year. A regression of tax liability observed in the income tax return data with the simulated TAXSIM output yields an $\mathrm{R}^{2}$ of 0.99 or more for each year.
} 
couples filing jointly. Similarly, thresholds were increased for couples filing separately and for singles. The reduction in tax revenue amounted to $2.89 \%$ of GDP (four year average, c.f. Tempalski (2006) for estimates of revenue effects mentioned in this section). Key aspects of TRA 86 were the broadening of the tax base and reductions in marginal tax rates. Overall, the reform was almost revenue neutral. ${ }^{12}$ TRA86 further lowered the top marginal rate to $38.5 \%$ in 1987 and to $28 \%$ in 1988, reduced the number of tax brackets from 15 in 1986 to four in 1988, but also substantially expanded the EITC with financial benefits for low-income households.

OBRA90 contained increases in income taxes as well as expansions of the EITC and other low-income credits. Furthermore, payroll taxes were increased by lifting the taxable maximum for Hospital Insurance which was finally abolished in 1994. OBRA93 then led to the largest single expansion of the EITC (cf. Eissa and Hoynes 2011), and further increases in income tax rates were implemented, e.g. the top rate rose from $31 \%$ to $39.6 \%$ in 1993 . The EITC became much more generous in 1994 with higher maximum credits and an expansion to single workers with no children. The EITC was further expanded in the following years. The revenue effect of OBRA90 and OBRA93 was - again evaluated on a four year average - positive and amounted to $0.5 \%$ and $0.63 \%$ of GDP, respectively. TRA97 lowered capital gains tax rates and introduced additional tax credits (child and education tax credits).

EGTRRA01 and JGTRRA03 were characterized by reductions in marginal tax rates, both for low- and high-income families, expansions of the child tax credits, and reductions in taxes on dividends. In 2003, JGTRRA accelerated those provisions of EGTRRA which were not set to become effective until 2006. Both reforms had a revenue-decreasing effect $(-0.71 \%$ and $-0.57 \%$ of GDP, 4 year average).

\section{Decomposition results}

\subsection{Major tax reforms}

We start our analysis by illustrating the decomposition procedure for each major tax reform in our sample period. In Table 3 in Appendix A.2, we compare average tax rates (including federal and state level income as well as payroll taxes) and post-tax income shares for various income groups before the start of the reform and after it was fully phased-in (base and end year). We decompose the total change into two components as explained in section 3. The first is due to tax reforms (policy effect) while the second is due to changes in the pre-tax income distribution (other effect). The left part of the table reports the different components of the decomposition, including base and end period baselines (columns (1) and (4) respectively), the two relevant counterfactuals as

\footnotetext{
${ }^{12}$ As part of the tax burden was effectively shifted from the individual to the corporate sector which is not part of our analysis, TRA86 constitutes a tax cut in the context of this paper.
} 
well as the total change. Columns (2) and (3) show the counterfactuals with average tax rates and income shares given end period pre-tax incomes and base period tax legislation (column 2), and base period pre-tax incomes and end period tax legislation (column 3). The right part of Table 3 reports both the policy and the other effect for decompositions I, II and the Shapley-value (i.e. the mean of the two decompositions). As they yield almost identical results in most cases, we will focus on the Shapleyvalue. An exception is TRA86 where the difference between decomposition I and II does matter which is discussed below.

Policy vs. other effect. The policy effect reveals how average tax rates and income shares would have changed under constant pre-tax incomes but changing policy. It is based on a counterfactual scenario in which the composition of pre-tax incomes remains constant, and pre-tax incomes grow in accordance with the inflation rate which is used for parameter adjustments in the counterfactuals. ${ }^{13}$ Adding the policy effect to the baseline values yields counterfactual values of average tax rates and income shares under 'constant pre-tax incomes', but changing policy parameters. A positive (negative) value of the other effect implies that the average tax rate of a given income group would have increased (decreased) in the absence of policy changes. This can either be due to pre-tax income growth above (below) the inflation rate or due to changes in the composition of pre-tax incomes or tax units. ${ }^{14}$ In the case of post-tax income shares, the interpretation slightly differs as an increase in the income share of one group automatically implies that the share of at least one other group must have decreased. Here, the other effect simply shows how income shares would have changed in the absence of any policy changes.

From 1981 to 1984, the period around ERTA81, average tax rates decreased for all income groups. Starting with the other effect, we observe that changes in pre-tax incomes have pushed average tax rates up only for the top $0.1 \%$ of the population. For all other income groups, average tax rate would have decreased even in the absence of the tax reform due to the the recessionary period in the early 1980s. Results for the policy effect show that with the exception of the second quintile, legislative changes led to reductions in average tax rates which were largest for the upper part of the income distribution. As an example, the cumulative policy effect from 1981 to 1984 reduced the average tax rate for those in the top $0.01 \%$ by 5.6 points, while the negative policy effect for the third and fourth quintile ( -0.1 and -0.7 , respectively) was only marginal. With regard to the absolute size of policy and other effect, the reduction in average tax rates due changes in pre-tax incomes was larger than the reduction caused by policy

\footnotetext{
${ }^{13}$ Results are robust when the adjustment of pre-tax incomes in the counterfactuals is based on mean nominal wage growth instead of the inflation rate (see section 4.4).

${ }^{14} \mathrm{~A}$ shift in the income composition to sources which are taxed by a lower rate ceteris paribus leads to a negative other effect.
} 
changes for taxpayers up to the fourth quintile. For those in the ninth decile and above, the absolute size of the policy effect was larger than the other effect. Moving to the effect of ERTA81 on inequality, we find that income shares for those below (above) the 80th percentile would have decreased (increased) in the absence of any policy changes. The policy effect strengthened this effect. We conclude that ERTA81 exacerbated the increase in inequality such that post-tax income shares were more unequal in 1984 compared with a counterfactual of no policy changes.

Contrary to ERTA81, TRA86 contained both inequality-increasing (reduction in top marginal tax rates) and -decreasing elements (expansion of EITC, tax base broadening). Table 3 reveals that it was mainly the top $1 \%$ which experienced substantial reductions in average tax rates and increases in their income shares. Furthermore, our decomposition for TRA86 shows that, it makes a difference if the policy and other effect are evaluated on base or end period data. This can be explained by behavioral reactions, in particular income shifting and timing responses. Capital gains realizations peaked in 1986 in anticipation of the increase in the marginal tax rate on realized long-term capital gains from $20 \%$ to $28 \%$ in 1987 . Furthermore, taxpayers shifted income from the corporate to the individual sector as a response to the reduction of the top marginal rate which fell from 1986 to 1988 in two steps from $50 \%$ to $28 \%$ and thus below the basic corporation income tax rate (see e.g. Auerbach 1988, Feenberg and Poterba 1993 and Slemrod 1996). ${ }^{15}$ For taxpayers in the top 1\%, the hypothetical average tax rate with 1988 policy parameters, but 1986 pre-tax incomes (column 3) would have been much higher than the observed average tax rate in 1988 (column 4) due to the fact that a substantially larger share of their income in 1986 consisted of long-term capital gains which were taxed at a higher rate in 1988. Conversely, the hypothetical average tax rate with 1988 pre-tax incomes, but 1986 policy parameters (column 2) picks up the effect of a larger share of wage and entrepreneurial income reported by affluent taxpayers in 1988. Differences between decompositions I and II are thus driven by behavioral responses of taxpayers which caused a dramatic change in their income composition around TRA $86 .^{16}$

OBRA90 and OBRA93 counteracted the growing inequality at that time - at least to some extent. Average tax rates for those below the 60th percentile would have declined even without any policy changes due to low income growth as shown by the

\footnotetext{
${ }^{15}$ For those in the top $1 \%$, entrepreneurial income made up $11.1 \%$ of their total income (excl. capital gains) in 1986 , but $21.2 \%$ in 1988 . Conversely, capital gains made up $38.8 \%$ of their total income (incl. capital gains) in 1986, but only 14.6\% in 1988 (see updated tables to Piketty and Saez (2003), accessible at http://elsa.berkeley.edu/ ${ }^{\sim}$ saez/).

${ }^{16}$ Note that the way we rank tax units, i.e. based on their pre-tax incomes excluding capital gains which are added back for the calculation of average tax rates and income shares, might critically affect our decomposition results when significant changes in the amount of realized capital gains occur from one period to the other. In section 4.4, we show how results change for TRA86 when tax units are ranked based on pre-tax incomes including capital gains, which provides additional evidence for the impact of behavioral changes around TRA86 on our decomposition results.
} 
negative other effect. In a similar vein, the other effect on post-tax income shares was negative for those below the 80th percentile implying that their income share would have declined substantially in the absence of the tax reforms. Due to expansions of the EITC the policy effect led to a considerable reduction in average tax rates of those in the lower half of the distribution, in particular in the second quintile, while increases in marginal rates caused average tax rates to rise in the upper half of the distribution. This effect was strongest at the top of the distribution where the policy effect increased average tax rates, for instance, for those in the top $0.01 \%$ by more than 11 percentage points. Unsurprisingly, the cumulative policy effect of OBRA90 and OBRA93 on the income share of the top $1 \%$ was negative, while it was positive for the rest of the population and again largest for those in the second quintile.

Decomposition results for EGTRRA01 and JGTRRA03 show that, similar to previous periods, the other effect pushed average tax rates up only for the top $1 \%$. The tax cuts enacted in 2001 and 2003, however, led to substantial reductions in average tax rates across the distribution, with strongest policy effects - in absolute terms - at the top of the distribution. The positive policy effect on the income share of those at the top underlines the inequality-increasing effect of the Bush tax cuts.

\subsection{Cumulative effects over time}

In this section, we focus on the cumulative effect of changes in policy and pre-tax incomes on average tax rates and income shares over the entire period.

Average tax rates. We first turn to the results for average tax rates. Figure 1 shows how the total average tax rate developed from 1979 to 2007 (black diamond). Additionally, we consider two counterfactual scenarios. These counterfactuals reveal how the average tax rate would have changed if either policy parameters or pre-tax incomes would have remained as observed in the base year 1979. Over the entire period, the policy effect (other effect) pushed the average tax rate down (up) as can be seen by the hollow (black) triangles. In particular, policy changes implemented in the 1980s and early 2000s had a dampening impact on the total average tax rate, while the reforms in the early 1990s to some extent reversed the Reagan tax cuts. If policy parameters had remained constant on their 1979 level, the total average tax rate would have almost constantly grown from 1982 until 2000. This is due to the fact that total income grew faster than the inflation rate which is used to adjust pre-tax incomes in the counterfactuals.

Clearly, any diverging trends across income groups are hidden behind this aggregate average tax rate. Therefore, in Figures 2 and 3, we plot changes in average tax rates for income quintiles and fractiles of the top 1\% comparing the actual change (left panel) with the counterfactual scenario of constant pre-tax incomes (right panel), respectively. 


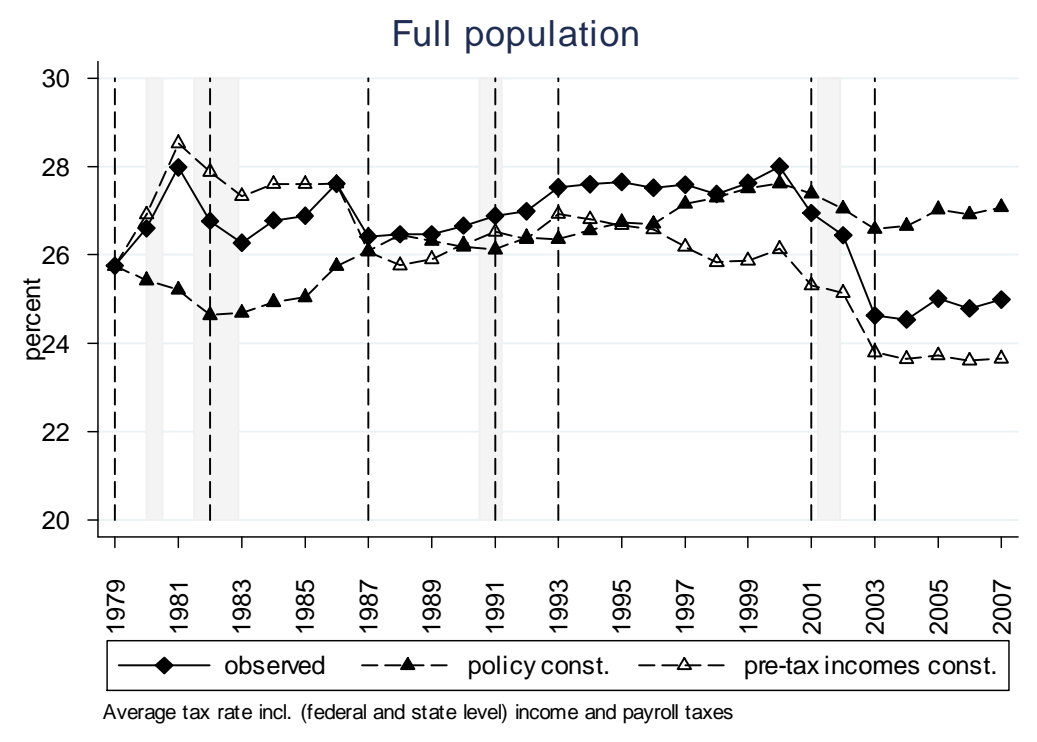

Note: The dashed vertical lines indicate the start of implementation of significant changes in tax legislation (section 3.4). Shaded areas show recession periods (NBER classification). Uprating according to the level of price inflation. Sources: Own calculations based on SOI IRS income tax return data and NBER TAXSIM calculator.

Importantly, the difference between these two series is given by the other effect capturing the impact of changes in pre-tax incomes on the average tax rate conditional on constant policy parameters.

We start with the income shares reported in Figure 2. Several important findings stand out. First, in absolute terms, the dampening policy effect on average tax rates was smallest for the third (P40-60) and fourth (P60-80) quintile and largest for the second (P20-40) and fifth (P80-100) quintile. Hence, it is the middle and upper middle class which benefited least from changes in tax policy. Second, taxpayers in the top quintile benefited more from tax policy than is visible in the left panel due to the fact that the other effect pushed their average tax rate up. The opposite is true for all other taxpayers for whom the other effect had a dampening effect on the average tax rate. Third, the right panel gives an indication of how the political cycle might have affected average tax rates at different parts of the income distribution. In short, the tax burden on high-income taxpayers (fourth and fifth quintile) was reduced under the Republican administrations in the 1980s and early 2000s, whereas low-income taxpayers (second quintile) faced largest reductions under the Democratic administrations in the 1990s. The picture for the third quintile is different as their tax burden first rose under Republican administrations in the 1980s, but was subsequently reduced to a similar extent under Democratic (1990s) and Republican (early 2000s) administrations - this 
Figure 2: Average tax rates for quintiles: Observed vs. Policy

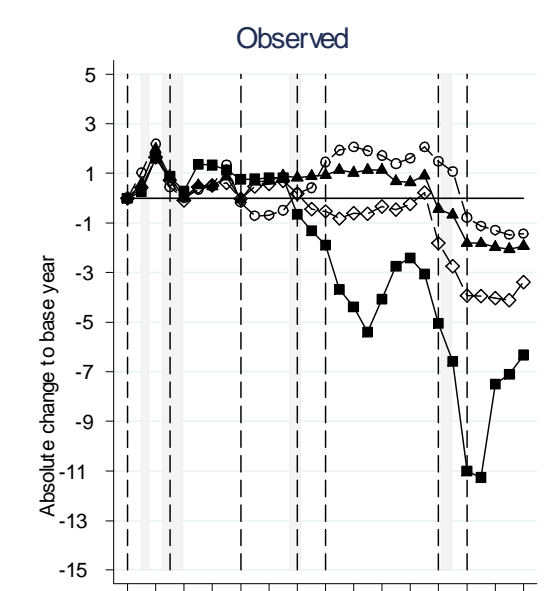

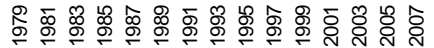

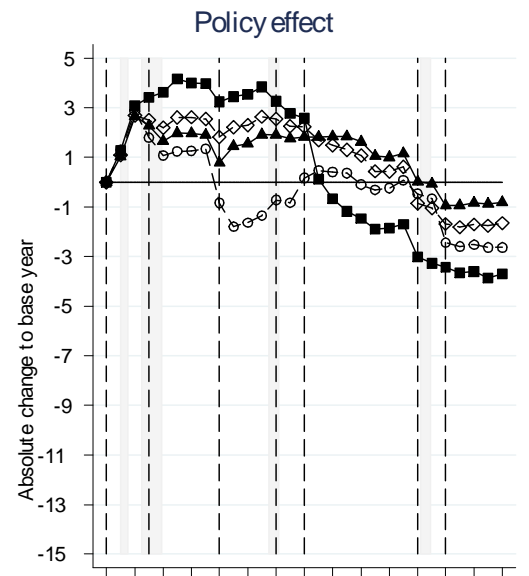

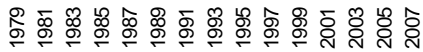

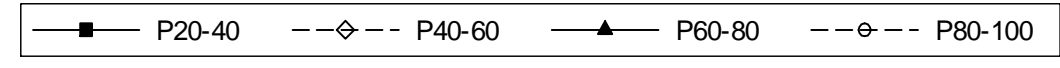

Average tax rate incl. (federal and state level) income and payroll taxes

Note: P20-40: Second quintile, P40-60: Third quintile, P60-80: Fourth quintile. P80-100: Fifth quintile. The dashed vertical lines indicate the start of implementation of significant changes in tax legislation (section 3.4). Shaded areas show recession periods (NBER classification). Uprating according to the level of price inflation. Sources: Own calculations based on SOI IRS income tax return data and NBER TAXSIM calculator.

will be investigated more thorougly in Section 5 .

Figure 3 reveals that policy changes affecting the top $1 \%$ of taxpayers had a much stronger impact on average tax rates than for the rest of the population. Even within this group, taxpayers were affected rather differently. Policy changes reduced the average tax rate of taxpayers located within the 99-99.5 fractile by roughly three percentage points, but by more than twelve points for those in the top $0.01 \%$ between 1979 and 2007. Observed changes in average tax rates were mainly driven by the policy effect. In contrast to results for taxpayers in the top quintile (Figure 2), the other effect did not push up average tax rates of the richest taxpayers despite the tremendous income growth this group experienced over the sample period. As discussed above, the negative other effect on average tax rates for those in the top $1 \%$ was largely due to the changing composition of their pre-tax incomes, partly caused by behavioral reactions around TRA 86.

Income shares. Now we turn to the effect of tax policy on inequality. The left panel of Figure 4 shows how post-tax income shares of taxpayers in the second to fifth quintile have changed relative to the base year pre-tax income share, while the policy effect on post-tax income shares is shown in the right panel. We find a stark contrast between 
Figure 3: Av. tax rates for fractiles of the top 1: Observed vs. Policy

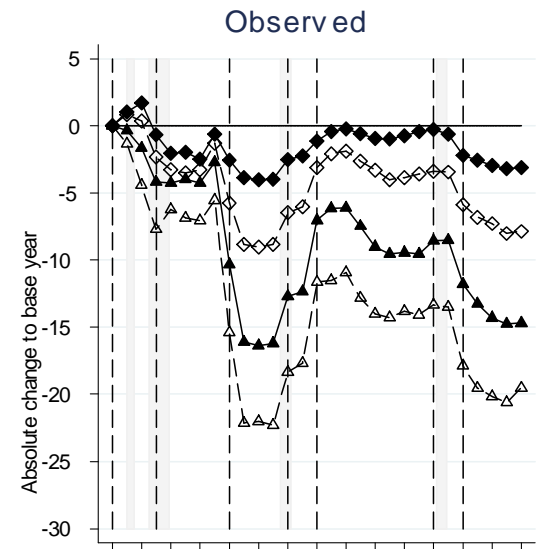

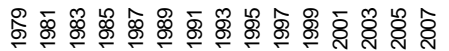

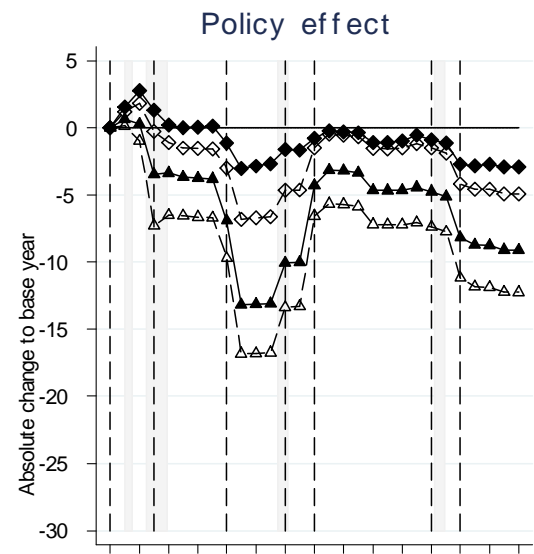

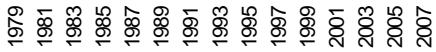

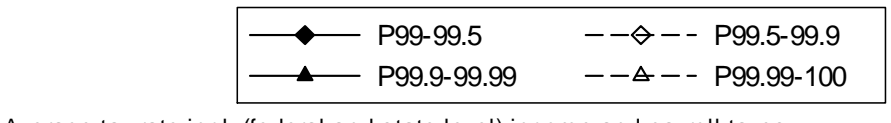

Average tax rate incl. (federal and state level) income and payroll taxes

Note: The graph shows changes for four fractiles within the top 1\%. The dashed vertical lines indicate the start of implementation of significant changes in tax legislation (section 3.4). Shaded areas show recession periods (NBER classification). Uprating according to the level of price inflation. Sources: Own calculations based on SOI IRS income tax return data and NBER TAXSIM calculator.

the observed change in income shares and the policy effect. The income share of those in the top quintile increased by roughly $24 \%$ over the whole sample period, whereas all other groups saw their income shares declining, with cumulative losses ranging from $22 \%$ (fourth quintile) to $28 \%$ (second quintile). Tax policy contributed to the increase (decrease) in the income share of those in the top (third and fourth) quintile with an overall policy effect of roughly $1 \%$ (minus $2 \%$ ). Remarkably, the cumulative policy effect on the income share of those in the second quintile almost canceled out over time. Tax policy was equalizing in some periods and disequalizing in others which is in line with the results for the policy effect on average tax rates. Again, the different sub-periods broadly coincide with the political cycle.

Figure 5 shows results for taxpayers in the top 1\%. As for average tax rates (Figure 3 ), observed changes in income shares as well as the policy effect were much larger at the top of the distribution than for any other income group. For instance, from 1979 to 2007 the income share of those in the top $0.01 \%$ has risen by $350 \%$ with the policy effect contributing $18 \%$ to the increase. Interestingly, the highly disequalizing policy effect in the 1980s was almost completely reversed after OBRA93, but the tax cuts in the early 2000s reinforced the overall increase in inequality. 
Figure 4: Income shares for quintiles: Observed vs. Policy

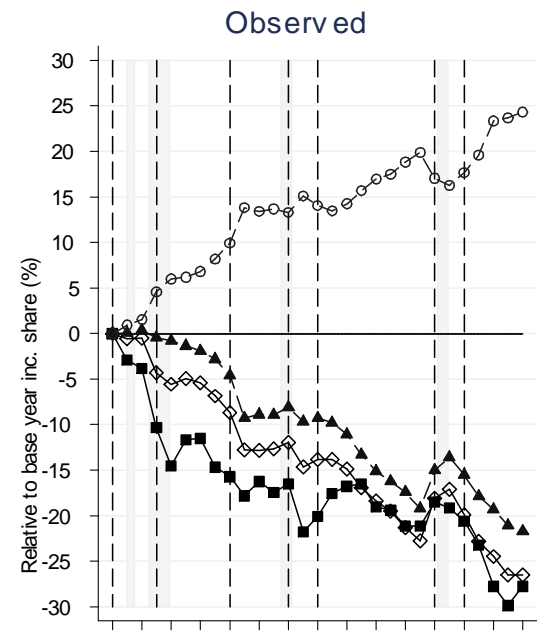

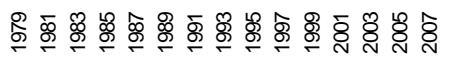

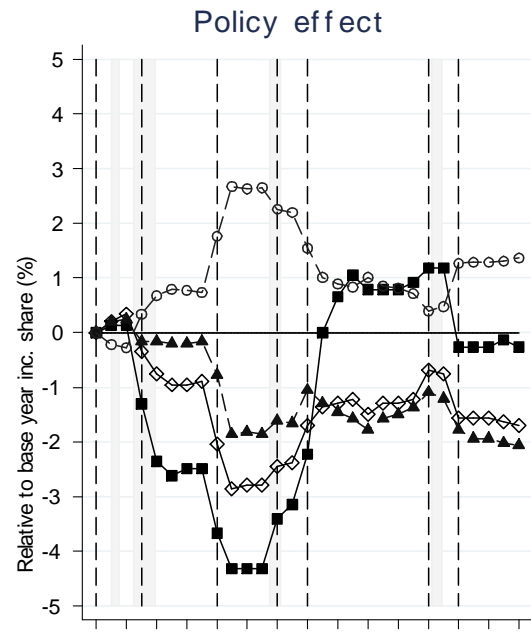

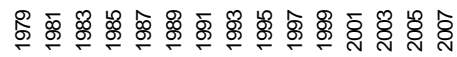

$$
\longrightarrow \mathrm{P} 20-40 \longrightarrow \mathrm{P} 40-60 \quad--\downarrow--\mathrm{P} 60-80 \quad--\theta--\mathrm{P} 80-100
$$

Note: P20-40: Second quintile, P40-60: Third quintile, P60-80: Fourth quintile. P80-100: Fifth quintile. The dashed vertical lines indicate the start of implementation of significant changes in tax legislation (section 3.4). Shaded areas show recession periods (NBER classification). Uprating according to the level of price inflation. Sources: Own calculations based on SOI IRS income tax return data and NBER TAXSIM calculator.

Relative importance. The difference in scale of the left- and right-hand side panels in Figures 4 and 5 suggests that changes in pre-tax incomes (the other effect) were the main driver of the total change in inequality. While this finding clearly confirms general perceptions about the roots of increasing inequality, it does not account for the fact, however, that the policy effect was equalizing in some periods and disequalizing in others and that these differential effects to some extent canceled out over the period of analysis. Calculating the mean of the absolute values of the policy effect and the total change, respectively, and expressing the former as a fraction of the latter, we find a non-trivial impact of policy changes. This is shown in Table 1 for average tax rates and income shares. Columns (1) and (3) present baseline results for the direct policy effect without behavioral reactions (see section 4.3 for the total policy effect including indirect policy effects). Unsurprisingly, column (1) reveals that policy changes matter more for average tax rates than changes in pre-tax incomes with the policy effect as a fraction of the total change ranging from $51 \%$ to $99 \%$ depending on the income group. Interestingly, the importance of the policy effect relative to the other effect is highest for taxpayers in the 95 th to 99 th percentile. The corresponding value for those in the top $1 \%$ is much smaller $(77.5 \%)$. The reason is that the other effect was larger for the 
Figure 5: Inc. shares for fractiles of the top 1: Observed vs. Policy

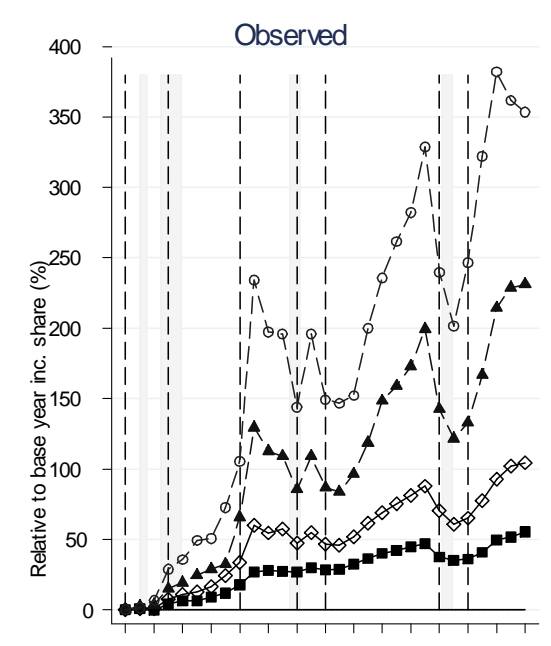

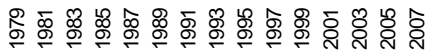

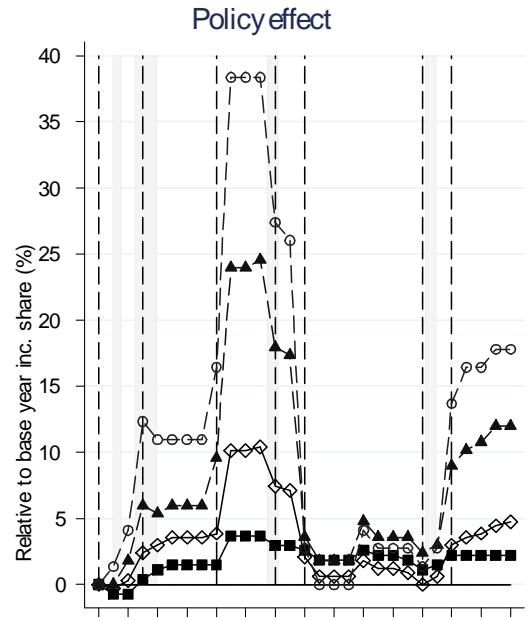

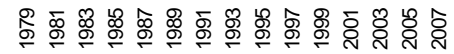

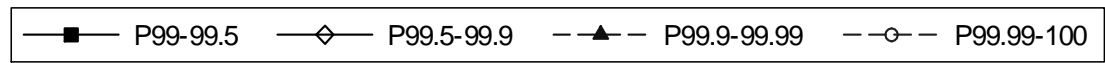

Note: The graph shows changes for four fractiles within the top 1\%. The dashed vertical lines indicate the start of implementation of significant changes in tax legislation (section 3.4). Shaded areas show recession periods (NBER classification). Uprating according to the level of price inflation. Sources: Own calculations based on SOI IRS income tax return data and NBER TAXSIM calculator.

top $1 \%$ than for those in the 95th to 99th percentile due to the tremendous income growth experienced by the richest taxpayers.

For income shares the mean (absolute) policy effect expressed relative to the mean (absolute) total change is lower, but still substantial and ranges between $11 \%$ to $29 \%$. Here, among all taxpayers the relative importance of the policy effect is smallest for those in the top $1 \%$ which again reflects the fact that pre-tax income growth was the main driver of their rising post-tax income shares. These findings are in line with Poterba (2007) who shows that the effect of changes in pre-tax incomes on the post-tax income distribution was four times as large as tax policy changes in the early 2000s.

\subsection{Indirect policy effects}

The baseline decomposition presented above abstracted from indirect policy effects which are captured by the other effect. Changes in pre-tax incomes may be unrelated to tax policy, but could also result from behavioral responses of taxpayers, in particular after significant changes in tax policy. For instance, it has been shown that the EITC reforms had a substantial impact on participation rates of married couples and single mothers (cf., Eissa and Hoynes 2006 and Eissa et al. 2008, among others). In addition 
Table 1: Relative importance of policy effect

\begin{tabular}{llllc}
\hline \hline & \multicolumn{2}{l}{ ETI=0 } & ETI=1 & \multicolumn{2}{l}{ ETI=0 } & ETI=1 \\
& Av. tax rates & \multicolumn{2}{l}{ Income shares } \\
& $(1)$ & $(2)$ & $(3)$ & $(4)$ \\
\hline P20-40 & 50.8 & 41.9 & 21.4 & 32.2 \\
P40-60 & 77.9 & 62.5 & 17.4 & 29.4 \\
P60-80 & 87.0 & 78.2 & 15.8 & 26.1 \\
P80-90 & 96.2 & 87.6 & 12.4 & 20.9 \\
P90-95 & 98.3 & 83.6 & 20.4 & 33.5 \\
P95-99 & 99.0 & 85.1 & 29.3 & 40.5 \\
P99-99.5 & 80.4 & 71.6 & 11.9 & 18.1 \\
P99.5-99.9 & 73.4 & 64.5 & 13.9 & 23.1 \\
P99.9-99.99 & 75.5 & 68.2 & 12.1 & 21.6 \\
P99.99-100 & 69.3 & 57.3 & 10.9 & 20.8 \\
Top 20\% & 94.6 & 87.9 & 19.2 & 28.3 \\
Top 10\% & 92.1 & 85.8 & 15.9 & 26.0 \\
Top 5\% & 89.0 & 83.0 & 14.2 & 24.8 \\
Top 1\% & 77.5 & 69.4 & 12.5 & 22.4 \\
\hline \hline
\end{tabular}

Note: The mean of the absolute values of the policy effect is expressed in $\%$ of the mean of the absolute values of the total effect. Average tax rates (\%) include federal and state level income and payroll taxes. Uprating according to the level of price inflation. Ranking based on pre-tax income excl. capital gains. Sources: Own calculations based on SOI IRS income tax return data and NBER TAXSIM calculator.

to adjustments in participation or hours worked, tax reforms may affect other margins such as tax evasion, income shifting or the timing of capital gains realizations with the latter two of particular relevance at the period around TRA86 (Auerbach 1988, Feenberg and Poterba 1993, Slemrod 1996, Auerbach and Slemrod 1997). The recognition of the importance of these responses has led to the growing tax responsiveness literature focusing on the ETI which shall capture all these behavioral responses (see Saez et al. 2012 for a survey).

In order to single out indirect policy effects in our decomposition framework, it is necessary to make assumptions about potential behavioral changes of taxpayers after policy changes. We proceed as follows. We extend our (mechanical) baseline decomposition and retrieve hypothetical pre-tax incomes for each income group in both counterfactuals by accounting for the ETI. Following Giertz (2009), who studies how tax revenues could be affected by behavioral responses after an expiration of the Bush tax cuts, we use stylized values of the ETI of 0.2, 0.5 and 1.0 in order to consider a reasonable range of values for the indirect policy effect (Saez et al. 2012). Note that our baseline decomposition can be considered as a lower bound as it is implicitly based on the assumption of a zero ETI. For the sake of simplicity, we assume the ETI to be 
constant across income groups (as in Giertz 2009) and over time. We are thus able to quantify what fraction of the total change in pre-tax income from period $t$ to $t+1$ is due to behavioral responses and other factors, respectively. The indirect policy effect is derived such that it precisely corresponds to that fraction of the other effect (see Appendix A.1 for a formal derivation).

Table 4 (Appendix A.2) shows decomposition results for all major tax reforms in our sample period including indirect policy effects. Columns (1)-(5) correspond to the baseline decomposition (Table 3), while columns (6)-(11) report results for indirect and residual effects. Note that the direct policy effect from our baseline (column (4)) is not affected by the extension as it mechanically captures changes in policy parameters, but no behavioral responses. On average, for an ETI of 0.2 , indirect policy effects are much smaller than direct policy effects. They become larger if we assume an ETI of 0.5 and are often as important as direct policy effects for an ETI of 1 .

In Figure 6, we relate the direct policy effect (equivalent to the right-hand side graph in Figure 4) to the upper bound estimate of the total policy effect which is given as the sum of direct and indirect policy effects. Results based on an underlying ETI of 0.2 and 0.5 are presented in Figures 7 and 8 in Appendix A.2. Importantly, our baseline results are quantitatively affected, but not qualitatively. ${ }^{17}$ Over the whole time period, taxpayers in the top quintile benefited most from tax policy and this effect is larger the higher the underlying ETI. The opposite effect can be observed for taxpayers in the second to fourth quintile.

In columns (2) and (4) of Table 1, the upper bound estimate for the total policy effect $(\mathrm{ETI}=1)$ is expressed in relation to the total change in average tax rates and income shares. While the fraction becomes smaller for average tax rates when indirect policy effects are accounted for (column (2) vs. (1)), the overall impact of tax policy on inequality becomes larger which amplifies the direct effect. It now ranges between $18 \%$ and $41 \%$.

\subsection{Sensitivity checks}

In this section, we check the sensitivity of our results with respect to several choices made.

Choice of the uprating factor. As a first sensitivity check, we replicate the analysis with mean nominal wage growth as uprating factor ( $\alpha$ in formulae (2) and (3)) in order to answer the question to what extent our results depend on the choice of the uprating

\footnotetext{
${ }^{17}$ An exception is the upper bound estimate on the total policy effect for taxpayers in the second quintile which turns out to be more negative than for taxpayers in the third quintile (Figure 6). For the total policy effect, it is important to note that a substantial part of the behavioral responses, in particular around TRA86, consisted of avoidance and timing responses which do not imply any additional income.
} 
Figure 6: Income shares: Direct vs. total policy effect with ETI=1

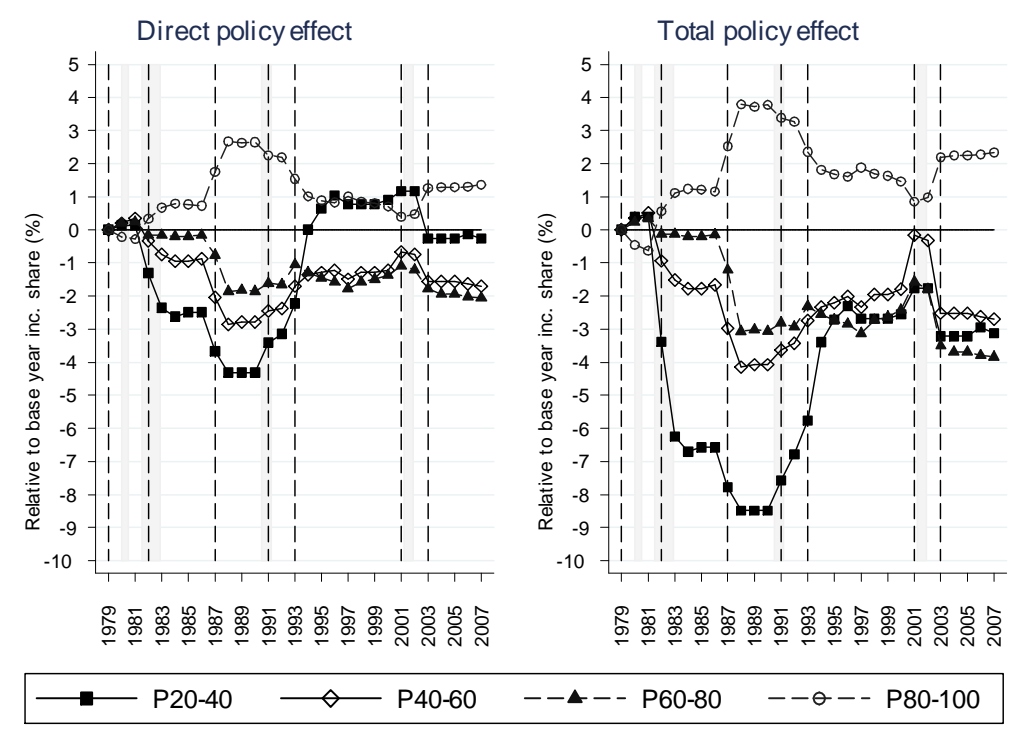

Note: P20-40: Second quintile, P40-60: Third quintile, P60-80: Fourth quintile. P80-100: Fifth quintile. The dashed vertical lines indicate the start of implementation of significant changes in tax legislation (section 3.4). Shaded areas show recession periods (NBER classification). ETI $=1$. Uprating according to the level of price inflation. Sources: Own calculations based on SOI IRS income tax return data and NBER TAXSIM calculator.

factor. Over the whole sample period, mean nominal wages grew faster than the inflation rate which implies that taxpayers might move into higher/lower tax brackets when adjusting pre-tax incomes in our counterfactuals. ${ }^{18}$ Figure 9 (Appendix A.2) shows that results do not change much with nominal wage indexation. The overall effect of tax policy is slightly more disequalizing than in our baseline. Cumulative policy effects on income shares are more beneficial for taxpayers in the fourth and fifth quintile relative to those in the the second and third quintile.

Ranking of tax units. In our baseline, we follow the approach of Piketty and Saez (2007) and rank tax units based on their pre-tax incomes excluding capital gains given that realized capital gains are not a regular stream of income. Capital gains are added back to pre- and post-tax incomes for the calculation of average tax rates and income shares. This might affect our results in particular for those periods in which significant changes in the amount of realized capital gains occurred, as can be observed around TRA86. Table 5 (Appendix A.2) shows decomposition results for TRA86 when tax

\footnotetext{
${ }^{18}$ We choose the National Average Wage Index according to which the taxable maximum for Social Security is automatically adjusted. See http://www.ssa.gov/OACT/COLA/AWI.html for further information. If the consumer price index (CPI-U-RS) and the National Average Wage Index are normalized to 1 for the base year 1979, their 2007 values are 2.66 and 3.52, respectively.
} 
units are ranked based on pre-tax incomes including capital gains. For the base year 1986, average tax rates appear to be substantially higher for taxpayers at the top $0.1 \%$ of the distribution than in our baseline (Table 3), whereas for 1988 average tax rates for the richest tax units are similar to those in our baseline. These differences can be explained by the fact that realizations of long-term capital gains peaked in 1986, in particular among affluent taxpayers, in anticipation of the tax increase in 1987.

The ranking of tax units also affects our decomposition results. This is especially evident when hypothetical average tax rates with 1986 pre-tax incomes and 1988 policy rules are compared (column (3) in Tables 3 and 5). The counterfactual average tax rate for taxpayers at the top $0.1 \%$ is substantially higher when taxpayers are ranked based on pre-tax incomes including capital gains. As a consequence, the beneficial effect of TRA86 for the richest taxpayers (top 1\%) appears to be much stronger in our baseline, while results for the bottom $99 \%$ do not critically depend on the way tax units are ranked. Decomposition results for all other tax reforms in our sample period are not affected by the way tax units are ranked.

SOI IRS vs. CPS data. In a previous version of this paper, we have conducted the decomposition analysis using data from the CPS. Results are not directly comparable due to various data issues such as the need to impute itemized deductions and topcoding of high incomes in the CPS. ${ }^{19}$ As a consequence, we have relied on percentile ratios such as the P90/P10, P90/P50 or P50/P10 and the Gini rather than (top) income shares for the calculation of the policy effect. Nevertheless, overall conclusions are the same. The policy effect is non-marginal, but smaller than the other effect. Tax policy was equalizing in the early 1990s, but highly disequalizing in the 1980s and early 2000s. A comparison of policy effects on the Gini coefficient based on these two data sources is shown in Figure 10 (Appendix A.2). For most years of our sample, the policy effects are of similar size.

\section{$5 \quad$ Partisan effects on inequality}

The previous analysis has shown that tax policy had a differential impact on inequality in different sub-periods which can be broadly classified by Republican and Democrat presidencies. Therefore, one interesting question that arises from our analysis is whether the direct policy effect on inequality is significantly affected by partisan politics. A key advantage of our policy effect compared to other outcome variables, such

\footnotetext{
${ }^{19}$ Furthermore, Burkhauser et al. (2012a) and Burkhauser et al. (2012b) have shown that to some extent, differences in inequality trends based on income tax return data and the CPS can be explained by different income measures and sharing units. Most notably, median income growth is substantially higher with the household instead of the tax unit as sharing unit and when economies of scale in household consumption are taken into account.
} 
as the total inequality level, is that it is solely affected by policymakers' decisions and not by pre-tax incomes. We are thus able to investigate the redistributive preferences of policymakers and hence the 'intended' impact of partisan tax policy on the income distribution.

In the U.S. the income tax burden is determined by both federal and state level tax policies implying both cross-sectional as well as time variation in the policy effect. In the following analysis, we exploit this heterogeneity across states and time. We estimate the partisan effect of the party of the U.S. President and of the legislative as well as the executive branch of state governments on the policy effect calculated for several distributional measures. We estimate an ordinary least squares (OLS) model similar to Reed (2006). The sample consists of 28 years of observations (1980-2007) from 47 states. We follow Reed (2006) and exclude Alaska and Hawaii and also Nebraska given that its state representatives do not formally affiliate with political parties. The main explanatory variables of the partisan tax policy effect on the U.S. income distribution are binary variables for partisan control over both chambers of the state legislature by the Democratic or the Republican party, respectively. The omitted category is split control between the two parties. Moreover, we include binary variables for state-year observations where a Republican governor is in power as well as for years where the U.S. President is a Republican. For the latter two party variables, the omitted category is Democratic Governor and Democratic President, respectively. Additionally, we control for a comprehensive set of (lagged) state and voter characteristics as well as state fixed effects in order to minimize any bias which might result from unmeasured voter preferences. Importantly, all explanatory variables are lagged by one period in order to avoid endogeneity problems. Descriptive statistics are reported in Table 6. The regression equation reads:

$$
P E_{s t}=\alpha+\beta P_{s t-1}+\delta R P_{t-1}+\gamma X_{s t-1}+\theta_{s}+\epsilon_{s t},
$$

where $P E_{s t}$ is the direct policy effect in state $s$ at time $t, P_{s t-1}$ is a vector of (lagged) partisan control variables for the state government, $R P_{t-1}$ is a binary variable for a Republican President, $X_{s t-1}$ is a vector of controls for state characteristics variables (as in Reed 2006), and $\theta_{s}$ are state fixed effects. In our regression model, identifying variation comes solely from states where partisan control over the executive or legislative branch has changed within the period under consideration. The party affiliation of the state governor has changed in all states except South Dakota which only had Republican governors. There are 7 (3) states where the Democrats (Republicans) exclusively controlled the legislature over the whole sample period and one state where the legislature was always split between Democrats and Republicans with no majority for one party.

Our baseline results are presented in Table 2 (Table 7 in the Appendix reports the 
Table 2: Partisan effect on inequality

\begin{tabular}{|c|c|c|c|c|c|c|c|c|c|}
\hline & (1) & $(2)$ & (3) & $(4)$ & $(5)$ & (6) & (7) & (8) & (9) \\
\hline Dep. var.: Policy effect & $\mathrm{P} 0-20$ & P20-40 & P40-60 & $\mathrm{P} 60-80$ & P80-100 & Top $10 \%$ & Top $5 \%$ & Top $1 \%$ & Gini \\
\hline Republican Governor & $\begin{array}{c}-0.0085^{* *} \\
(-2.4958)\end{array}$ & $\begin{array}{c}-0.0123^{* * * *} \\
(-3.1957)\end{array}$ & $\begin{array}{c}-0.0045 \\
(-1.3042)\end{array}$ & $\begin{array}{l}-0.0068 \\
(-1.3920)\end{array}$ & $\begin{array}{c}0.0315^{* * *} \\
(2.7747)\end{array}$ & $\begin{array}{c}0.0388^{* * *} \\
(2.9753)\end{array}$ & $\begin{array}{c}0.0396^{* * *} \\
(2.8625)\end{array}$ & $\begin{array}{c}0.0356^{* * *} \\
(2.9502)\end{array}$ & $\begin{array}{c}0.0440^{* * * *} \\
(3.5971)\end{array}$ \\
\hline Observations & 1,316 & 1,316 & 1,316 & 1,316 & 1,316 & 1,316 & 1,316 & 1,316 & 1,316 \\
\hline R-squared & 0.1341 & 0.1661 & 0.1666 & 0.0668 & 0.1688 & 0.0936 & 0.0490 & 0.0467 & 0.1343 \\
\hline Mean dep. var. & -0.003 & -0.001 & -0.007 & -0.015 & 0.026 & 0.022 & 0.015 & 0.010 & 0.016 \\
\hline Std.Dev. dep. var. & 0.053 & 0.062 & 0.058 & 0.075 & 0.188 & 0.204 & 0.219 & 0.185 & 0.196 \\
\hline H0: Dem. L. = Rep. L. & 0.153 & 0.000 & 0.000 & 0.148 & 0.000 & 0.000 & 0.003 & 0.003 & 0.000 \\
\hline
\end{tabular}

Note: In columns (1)-(8), dependent variable is the state-level policy effect on the income share of various income groups. In column (9), dependent variable is the state-level Gini coefficient. All specifications include state fixed effects and controls as reported in Table 7. We estimate robust standard errors. The last row shows p-values for the hypothesis test

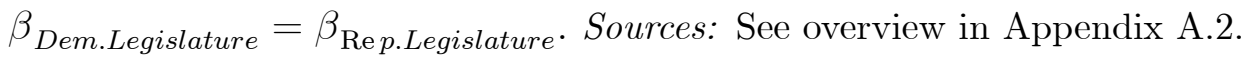

full model including all control variables). Columns (1)-(8) show regression results for the policy effect on the income share of various income groups in each state's income distribution while in column (9) the policy effect on the Gini coefficient is used as inequality measure. Contrary to the previous analysis, non-filers are not imputed here such that the bottom quintile consists of the poorest $20 \%$ of taxpayers in each state's income distribution. Focus first on the partisan effect of the state legislature. The coefficients for Democratic Legislature are significant and have a positive sign when the policy effect on the income share of the bottom four quintiles is our dependent variable (columns (1)-(4)), but a negative sign in all other specifications. The within-estimator implies that we can calculate the difference between the coefficients on Democratic and Republican Legislature in order to gauge the partisan effect. For example, a change from a Republican to a Democratic state legislature, ceteris paribus, increases the income share of taxpayers in the second and third quintile by roughly 0.02-0.03 percentage points, but decreases the income share of taxpayers in the fifth quintile by 0.07 points. As a consequence, Democratic legislatures have reduced overall inequality as shown by the negative sign of the Gini coefficient in column (9). The hypothesis test that the coefficients for Democratic and Republican Legislature are equal can be rejected at the 1\%-level for all specifications ( $\mathrm{p}$-values are reported in the last row of the table) except for those in columns (1) and (4), where the policy effect on the first and fourth quintile is used as dependent variable.

Turning next to the gubernatorial (state) tax policy effect on inequality, we find that with the exception of the models in columns (3) and (4), the coefficients on Republican Governor are significant and have the opposite sign than those on Democratic 
Legislature implying that state income taxes had an inequality-increasing effect after a switch from a Democratic to a Republican Governor. The same conclusion can be drawn for tax policy changes on the federal level with the Republican President time dummy being significant and of negative sign in columns (1)-(4) and positive in columns (5)-(9), albeit not significant for the policy effect on the income share of the top $1 \%$ in a state.

Our results suggest that tax policy of the Democrats is geared towards taxpayers up to the fourth quintile, while Republicans seem to target taxpayers in the top quintile. Even though our estimates appear to be small, they have a non-negligible effect on changes in inequality. The size of the coefficients should be compared with the average policy effect (see bottom of Table 2) as well as the mean change in post-tax income shares (see Table 6). In general, the political party coefficients are substantially larger than the average yearly policy effect in absolute terms. Moreover, the partisan effect of a switch from a Republican to a Democratic legislature relative to the average total change in post-tax inequality can be calculated by taking the difference between the Democratic and Republican Legislature coefficients and dividing this number by the mean change in the corresponding inequality measure. We find that the partisan effect of controlling both chambers of the state legislature makes up $23-42 \%$ of the total change in post-tax inequality with the largest effect for the income share of taxpayers in the second quintile. The corresponding gubernatorial effect relative to the mean change in inequality ranges between 12-37\%. Hence, we conclude that partisan tax policy has not only a statistically significant effect on U.S. income distribution, but is also economically important.

Sensitivity analysis. These baseline results are robust with respect to several different model specifications. For example, we have estimated the same model including interactions between partisan control over the legislative and the executive branch within states or interactions between the party of the President and control of the Congress. This does not alter the general pattern of Republicans increasing inequality especially at the top and Democrats increasing the income share of the bottom $80 \%$ of the distribution (results available upon request). Moreover, we have estimated a model where the Republican President dummy is replaced by time fixed effects for federal legislative terms. Table 8 confirms that partisan effects for state governments are of similar size as in our baseline model. Aggregating the data to 5-year averages as suggested by Reed (2006) reduces the number of state-year observations significantly and causes the policy effect to cancel out in some of the 5-year periods. As a consequence partisan effects become smaller and less significant (results available upon request). 


\section{Conclusion}

In this paper, we have analyzed how tax policy has affected post-tax income inequality in the U.S. from 1979 to 2007 based on counterfactual simulations. The decomposition analysis has enabled us to isolate and quantify the direct effect of tax policy on the posttax income distribution. A main finding of our analysis is that, over the whole sample period, tax policy aggravated the trend of growing inequality in pre-tax incomes: tax policy had a positive (negative) effect on the income share of taxpayers above (below) the 80th percentile. Hence, without any tax policy changes, observed inequality would be lower nowadays. A second key result is that the policy effect corresponds to 11$29 \%$ of the total change in income shares of different income groups. The effect was largest for taxpayers in the 95th to 99th percentile but smallest for those in the top $1 \%$. Thus, even though the surge in top incomes in the last three decades was to a large extent market driven, tax policy explains a substantial part of this trend. In addition, accounting for indirect policy effects due to behavioral responses does not change our results qualitatively, but raises the relative importance of the policy effect on inequality: the upper bound estimate for the total policy effect is $18-41 \%$ (depending on the inequality measure) of the total change.

Our analysis has also shown that tax reforms in the 1980s and early 2000s exacerbated trends of growing inequality while those in the early 1990s benefited low-income taxpayers. As these periods coincide with Republican and Democratic administrations, we have additionally analyzed how the political cycle in the U.S. has affected inequality. For our estimates of partisan effects, we have exploited the fact that the policy effect is independent of all other factors beyond the control of policymakers. Our results suggest that tax reforms passed by Republican governments had a positive effect on the income shares of taxpayers in the top quintile, whereas Democrats targeted the bottom $80 \%$ of the income distribution. The partisan effect of controlling either the legislative or the executive branch of state governments accounted for $12-42 \%$ of the total change in post-tax inequality.

Our analysis has to be interpreted in the light of the following qualifications. First, our analysis is purely positive. Throughout this paper, we have abstracted from normative welfare considerations regarding the optimal amount of redistribution. Second, the calculation of indirect policy effects is based on stylized assumptions about behavioral responses to tax changes. However, we have used a range of plausible parameter values for the ETI and found qualitatively similar results. Third, we have focused the analysis on the U.S.. In future research, it would be interesting to replicate our analysis for other countries in order to investigate if (partisan) tax policy affects inequality differently across different institutional settings. 


\section{References}

Alm, J., Lee, F. and Wallace, S. (2005). How fair? Changes in federal income taxation and the distribution of income, 1978 to 1998, Journal of Policy Analysis and Management 24 (1): 5-22.

Anderson, S. and Habel, P. (2009). Revisiting adjusted ADA scores for the U.S. Congress, 1947-2007, Political Analysis 17: 83-88.

Auerbach, A. (1988). Capital Gains Taxation in the United States, Brookings Papers on Economics Activity 19 (2): 595-638.

Auerbach, A. and Slemrod, J. (1997). The Economic Effects of the Tax Reform Act of 1986, Journal of Economic Literature XXXV: 589-632.

Bakija, J., Cole, A. and Heim, B. (2012). Jobs and income growth of top earners and the causes of changing income inequality: Evidence from U.S. tax return data, Working paper, Williams College.

Bargain, O. and Callan, T. (2010). Analysing the effects of tax-benefit reforms on income distribution: A Decomposition Approach, Journal of Economic Inequality 8 (1): $1-21$.

Bartels, L. (2008). Unequal Democracy - The Political Economy of the New Gilded Age, Princeton University Press.

Bourguignon, F. and Spadaro, A. (2006). Microsimulation as a tool for evaluating redistribution policies, Journal of Economic Inequality 4(1): 77-106.

Burkhauser, R., Feng, S., Jenkins, S. and Larrimore, J. (2011). Trends in United States Income Inequality Using the March Current Population Survey: The Importance of Controlling for Censoring, Journal of Economic Inequality 9(3): 393-415.

Burkhauser, R., Feng, S., Jenkins, S. and Larrimore, J. (2012a). Recent trends in top income shares in the USA: Reconciling estimates from March CPS and IRS tax return data, Review of Economics and Statistics 94(2): 371-388.

Burkhauser, R., Larrimore, J. and Simon, K. (2012b). A "second opinion" on the economic health of the American middle class, National Tax Journal 65 (1): 7-32.

Clark, T. and Leicester, A. (2004). Inequality and two decades of British tax and benefit reform, Fiscal Studies 25 (2): 129-158.

Congressional Budget Office (2010). Average federal tax rates and income, by income category, 1979-2007, Accessed at http://www.cbo.gov/publications/collections/collections.cfm?collect=13. 
Dardanoni, V. and Lambert, P. (2002). Progressivity comparisons, Journal of Public Economics 86: 99-122.

DeBacker, J., Heim, B., Panousi, V. and Vidangos, I. (2012). Rising inequality: Transitory or Permanent? New evidence form a panel of U.S. tax returns 1987-2006, Available at SSRN: http://ssrn.com/abstract $=1747849$.

Diamond, P. and Saez, E. (2011). The Case for a Progressive Tax: From Basic Research to Policy Recommendations, Journal of Economic Perspectives 25 (4): 165-190.

Eissa, N. and Hoynes, H. (2006). Behavioral Responses to Taxes: Lessons from the EITC and Labor Supply, in Tax Policy and the Economy 20, M.I.T. Press, 74-110.

Eissa, N. and Hoynes, H. (2011). Redistribution and Tax Expenditures: The Earned Income Tax Credit, National Tax Journal 64 (2): 689-730.

Eissa, N., Kleven, H. and Kreiner, C. T. (2008). Evaluation of four tax reforms in the Unites States: Labor supply and welfare effects for single mothers, Jounal of Public Economics 92: 795-816.

Feenberg, D. and Poterba, J. (1993). Income inequality and the incomes of very highincome taxpayers: Evidence from tax returns, in Tax Policy and the Economy 7, edited by James M. Poterba, M.I.T. Press, 145-177.

Feenberg, D. R. and Coutts, E. (1993). An Introduction to the TAXSIM Model, Journal of Policy Analysis and Management 12(1): 189-194.

Giertz, S. (2009). The Elasticity of Taxable Income: Influences on Economic Efficiency and Tax Revenues, and Implications for Tax Policy, in Tax Policy Lessons from the 2000s, ed. Alan Viard, 101-136. Washington, DC: AEI Press.

Gottschalk, P. and Danziger, S. (2005). Inequality of wage rates, earnings and family income in the United States, 1975-2002, Review of Income and Wealth 51 (2): 231254.

Gottschalk, P. and Smeeding, T. (1997). Cross-national comparisons of earnings and income inequality, Journal of Economic Literature 35: 633-87.

Gramlich, E., Kasten, R. and Sammartino, F. (1993). Growing inequality in the 1980s: The role of federal taxes and cash transfers, In Uneven tides: Rising inequality in America, ed. Sheldon Danziger and Peter Gottschalk, 225-49. New York: Russell Sage Foundation.

Heathcote, J., Perri, F. and Violante, G. (2010). Unequal we stand: An empirical analysis of economic inequality in the United States, 1967-2006, Review of Economic Dynamics 13 (1): 15-51. 
Hirsch, B., Macpherson, D. and Vroman, W. (2001). Estimates of Union Density by State, Monthly Labor Review 124: 51-55.

Kasten, R., Sammartino, F. and Toder, E. (1994). Trends in federal tax progressivity, 1980-93, In Tax progressivity and income inequality, ed. J. Slemrod, 9-50. Cambridge: Cambridge University Press.

Klarner, C. (2003). Measurement of the Partisan Balance of State Government, State Politics and Policy Quarterly 3: 309-319.

Lambert, P. and Thoresen, T. (2009). Base independence in the analysis of tax policy effects: with an application to Norway 1992-2004, International Tax and Public Finance 16: 219-252.

Leigh, A. (2008a). Do redistributive state taxes reduce inequality?, National Tax Journal 61 (1): 81-104.

Leigh, A. (2008b). Estimating the impact of gubernatorial partisanship on policy settings and economic outcomes: A regression discontinuity approach, European Journal of Political Economy 24: 256-268.

McCarty, N. and Pontusson, J. (2009). The political economy of inequality and redistribution, In The Oxford Handbook of Economic Inequality.

Meyer, B. (2010). The effects of the Earned Income Tax Credit and recent reforms, in Tax Policy and the Economy 24, edited by Jeffrey Brown, M.I.T. Press, 153-180.

Mitrusi, A. and Poterba, J. (2000). The Distribution of Payroll and Income Tax Burdens, 1979-99, National Tax Journal 53 (3): 765-794.

Musgrave, R. and Thin, T. (1948). Income tax progression, 1929-1948, Journal of Political Economy 56: 498-514.

OECD (2011). Divided we stand: Why inequality keeps rising, OECD Publishing.

Pettersson-Lidbom, P. (2008). Do parties matter for economic outcomes? A regressiondiscontinuity approach, Journal of the European Economic Association 6(5): 10371056.

Piketty, T. and Saez, E. (2003). Income Inequality in the United States, 1913-1998, Quarterly Journal of Economics CXVIII (1): 1-39.

Piketty, T. and Saez, E. (2007). How Progressive is the U.S. Federal Tax System? A Historical and International Perspective, Journal of Economic Perspectives 21 (1): $3-24$. 
Piketty, T., Saez, E. and Stantcheva, S. (2011). Optimal taxation of top labor incomes: A tale of three elasticities, NBER Working Paper 17616.

Poterba, J. (2007). Income inequality and income taxation, Journal of Policy Modeling 29: $623-633$.

Reed, W. R. (2006). Democrats, republicans, and taxes: Evidence that political parties matter, Journal of Public Economics 90: 725-750.

Saez, E. (2003). The effect of marginal tax rates on income: a panel study of 'bracket creep', Journal of Public Economics 87: 1231-1258.

Saez, E., Slemrod, J. and Giertz, S. (2012). The elasticity of taxable income with respect to marginal tax rates: A critical review, Journal of Economic Literature 50:1: 3-50.

Scheve, K. and Stasavage, D. (2009). Institutions, partisanship, and inequality in the long run, World Politics 61 (2): 215-253.

Shorrocks, A. (1999). Decomposition Procedures for Distributional Analysis: A Unified Framework based on the Shapley Value, University of Essex and Institute for Fiscal Studies, Wivenhoe Park.

Slemrod, J. (1992). Taxation and inequality: A time-exposure perspective, in Tax Policy and the Economy 6, edited by James Poterba, M.I.T. Press, 105-127.

Slemrod, J. (1996). High-Income Families and the Tax Changes of the 1980s: The Anatomy of Behavioral Response, In Empirical Foundations of Household Taxation, ed. M. Feldstein and J. Poterba, 169-192. University of Chicago Press.

Tempalski, J. (2006). Revenue effects of major tax bills, Office of Tax Analysis Working Paper 81. 


\section{A Appendix:}

\section{A.1 Decomposition including indirect policy effect}

We extend decompositions I and II as follows:

Decomposition I:

$$
\begin{aligned}
\Delta M= & \underbrace{M\left[d_{t+1}\left(p^{t+1}, y^{t+1}\right)\right]-M\left[d_{t}\left(p^{t}, \frac{y^{t+1}}{\alpha^{t+1}}\right)\right]}_{\text {policy effect I }} \\
& +\underbrace{M\left[d_{t}\left(p^{t}, \frac{y^{t+1}}{\alpha^{t+1}}\right)\right]-M\left[d_{t}\left(p^{t}, \frac{y}{\alpha^{t+1}}\right)\right]}_{\text {indirect policy effect I }} \\
& +\underbrace{M\left[d_{t}\left(p^{t}, \frac{\tilde{y}^{t+1}}{\alpha^{t+1}}\right)\right]-M\left[d_{t}\left(p^{t}, y^{t}\right)\right]}_{\text {residual effect I }}
\end{aligned}
$$

Decomposition II:

$$
\begin{aligned}
\Delta M= & \underbrace{M\left[d_{t+1}\left(p^{t+1}, y^{t+1}\right)\right]-M\left[d_{t+1}\left(p^{t+1}, \alpha^{t+1} \tilde{y}^{t}\right)\right]}_{\text {residual effect II }} \\
& +\underbrace{M\left[d_{t+1}\left(p^{t+1}, \alpha^{t+1} y\right)\right]-M\left[d_{t}\left(p^{t+1}, \alpha^{t+1} y^{t}\right)\right]}_{\text {indirect policy effect II }} . \\
& +\underbrace{M\left[d_{t+1}\left(p^{t+1}, \alpha^{t+1} y^{t}\right)\right]-M\left[d_{t}\left(p^{t}, y^{t}\right)\right]}_{\text {policy effect II }}
\end{aligned}
$$

with $\tilde{y}^{t}$ and $\tilde{y}^{t+1}$ as vectors of hypothetical pre-tax incomes after behavioral responses. The ETI-formula reads:

$$
\varepsilon=\frac{\Delta y}{\Delta(1-T)} * \frac{1-T}{y}
$$

The behavioral response is calculated for decompositions I and II:

$$
\begin{aligned}
& \Delta y^{I}=\varepsilon * \Delta(1-T) * \frac{y^{t+1}}{(1-T)_{t+1}}(\text { decomposition I }) \\
& \Delta y^{I I}=\varepsilon * \Delta(1-T) * \frac{y^{t}}{(1-T)_{t}}(\text { decomposition II })
\end{aligned}
$$

with $\varepsilon=0.2,0.5$ or $1, \Delta(1-T)$ given by the policy effect on average tax rates, $T$ average tax rates and $y^{t} / y^{t+1}$ observed pre-tax incomes in $t$ and $t+1$. Averaging over both decompositions yields the Shapley value: 


$$
\Delta y^{S}=\frac{\Delta y^{I}+\Delta y^{I I}}{2}
$$

For each income group, the indirect policy effect is calculated as a fraction of the total change in reported income from period $t$ to $t+1$ :

$$
I P E=\frac{\Delta y^{S}}{y^{t+1}-y^{t}} * O E
$$

\section{A.2 Additional results}


Table 3: Decomposition results for major tax reforms

(a) ERTA81

\begin{tabular}{|c|c|c|c|c|c|c|c|c|c|c|c|}
\hline \multirow{5}{*}{$\begin{array}{l}\text { data year: } \\
\text { adjusted to: } \\
\text { policy year }\end{array}$} & \multirow{3}{*}{$\begin{array}{l}1981 \\
1981\end{array}$} & \multirow{2}{*}{$\begin{array}{l}1984 \\
1981\end{array}$} & \multirow{2}{*}{$\begin{array}{l}1981 \\
1984\end{array}$} & \multirow[t]{2}{*}{1984} & \multirow{3}{*}{$\begin{array}{l}\text { Total } \\
\text { change }\end{array}$} & \multicolumn{2}{|c|}{ Decomp. I } & \multicolumn{2}{|c|}{ Decomp. II } & \multicolumn{2}{|c|}{ Shapley-Dec. } \\
\hline & & & & & & Policy & Other & $\mathrm{PE}$ & $\mathrm{OE}$ & $\mathrm{PE}$ & $\mathrm{OE}$ \\
\hline & & 1981 & 1984 & 1984 & & & & & & Mean & Mean \\
\hline & & & & & & & & & & $(4)-(2)$ & $(2)-(1)$ \\
\hline & $(1)$ & $(2)$ & $(3)$ & $(4)$ & $(4)-(1)$ & $(4)-(2)$ & $(2)-(1)$ & $(3)-(1)$ & $(4)-(3)$ & $(3)-(1)$ & $(4)-(3)$ \\
\hline \multicolumn{12}{|c|}{ Average tax rates } \\
\hline P20-40 & 15.1 & 13.8 & 16.2 & 14.9 & -0.3 & 1.1 & -1.3 & 1.1 & -1.3 & 1.1 & -1.3 \\
\hline P 40-60 & 22.3 & 21.2 & 22.2 & 21.2 & -1.2 & -0.1 & -1.1 & -0.1 & -1.1 & -0.1 & -1.1 \\
\hline P60-80 & 26.9 & 26.1 & 26.2 & 25.5 & -1.4 & -0.6 & -0.8 & -0.7 & -0.7 & -0.7 & -0.8 \\
\hline P $80-90$ & 29.4 & 28.7 & 28.5 & 27.9 & -1.5 & -0.8 & -0.7 & -0.9 & -0.6 & -0.9 & -0.6 \\
\hline P90-95 & 30.6 & 30.0 & 29.4 & 28.9 & -1.7 & -1.1 & -0.6 & -1.2 & -0.5 & -1.1 & -0.6 \\
\hline P95-99 & 32.5 & 31.7 & 30.7 & 30.0 & -2.5 & -1.7 & -0.7 & -1.8 & -0.7 & -1.8 & -0.7 \\
\hline P99-99.5 & 36.0 & 35.0 & 33.1 & 32.4 & -3.7 & -2.6 & -1.0 & -2.9 & -0.8 & -2.8 & -0.9 \\
\hline P99.5-99.9 & 39.8 & 39.0 & 36.2 & 35.9 & -3.9 & -3.1 & -0.8 & -3.5 & -0.3 & -3.3 & -0.5 \\
\hline P99.9-99.99 & 44.5 & 46.0 & 40.5 & 42.2 & -2.3 & -3.9 & 1.6 & -4.0 & 1.7 & -3.9 & 1.6 \\
\hline P99.99-100 & 46.9 & 50.3 & 41.6 & 44.5 & -2.4 & -5.8 & 3.4 & -5.3 & 2.9 & -5.6 & 3.1 \\
\hline Top $20 \%$ & 32.2 & 31.9 & 30.5 & 30.4 & -1.8 & -1.6 & -0.3 & -1.6 & -0.2 & -1.6 & -0.2 \\
\hline Top $10 \%$ & 33.7 & 33.6 & 31.7 & 31.6 & -2.1 & -1.9 & -0.2 & -2.0 & -0.1 & -2.0 & -0.1 \\
\hline Top $5 \%$ & 35.5 & 35.4 & 33.0 & 33.0 & -2.4 & -2.4 & -0.0 & -2.5 & 0.1 & -2.4 & 0.0 \\
\hline Top 1\% & 40.1 & 40.6 & 36.6 & 37.2 & -2.9 & -3.4 & 0.5 & -3.5 & 0.6 & -3.5 & 0.6 \\
\hline \multicolumn{12}{|c|}{ Post-tax income shares } \\
\hline P20-40 & 8.6 & 8.2 & 8.3 & 8.0 & -0.6 & -0.2 & -0.4 & -0.2 & -0.4 & -0.2 & -0.4 \\
\hline P $40-60$ & 15.7 & 15.2 & 15.5 & 15.1 & -0.7 & -0.2 & -0.5 & -0.2 & -0.5 & -0.2 & -0.5 \\
\hline $\mathrm{P} 60-80$ & 25.4 & 25.0 & 25.2 & 24.9 & -0.4 & -0.1 & -0.3 & -0.1 & -0.3 & -0.1 & -0.3 \\
\hline P $80-90$ & 18.0 & 18.1 & 18.0 & 18.1 & 0.2 & 0.0 & 0.1 & 0.0 & 0.1 & 0.0 & 0.1 \\
\hline P90-95 & 11.3 & 11.6 & 11.4 & 11.6 & 0.3 & 0.0 & 0.2 & 0.1 & 0.2 & 0.1 & 0.2 \\
\hline P95-99 & 12.1 & 12.6 & 12.3 & 12.8 & 0.6 & 0.2 & 0.5 & 0.2 & 0.5 & 0.2 & 0.5 \\
\hline P99-99.5 & 2.3 & 2.4 & 2.4 & 2.5 & 0.2 & 0.1 & 0.1 & 0.1 & 0.1 & 0.1 & 0.1 \\
\hline P99.5-99.9 & 2.7 & 2.9 & 2.8 & 3.0 & 0.4 & 0.1 & 0.3 & 0.1 & 0.3 & 0.1 & 0.3 \\
\hline P99.9-99.99 & 1.2 & 1.5 & 1.3 & 1.6 & 0.3 & 0.1 & 0.3 & 0.1 & 0.3 & 0.1 & 0.3 \\
\hline P99.99-100 & 0.5 & 0.8 & 0.5 & 0.8 & 0.3 & 0.1 & 0.3 & 0.0 & 0.3 & 0.0 & 0.3 \\
\hline Top $20 \%$ & 48.1 & 49.9 & 48.7 & 50.4 & 2.3 & 0.6 & 1.8 & 0.5 & 1.8 & 0.5 & 1.8 \\
\hline Top $10 \%$ & 30.1 & 31.8 & 30.7 & 32.3 & 2.2 & 0.5 & 1.7 & 0.5 & 1.7 & 0.5 & 1.7 \\
\hline Top 5\% & 18.8 & 20.2 & 19.3 & 20.7 & 1.9 & 0.5 & 1.4 & 0.5 & 1.4 & 0.5 & 1.4 \\
\hline Top 1\% & 6.7 & 7.6 & 7.0 & 7.9 & 1.2 & 0.3 & 0.9 & 0.3 & 1.0 & 0.3 & 0.9 \\
\hline
\end{tabular}

Note: PE: Policy effect. OE: Other effect. Average tax rates (\%) include federal and state level income and payroll taxes. Uprating according to the level of price inflation. Sources: Own calculations based on SOI IRS income tax return data and NBER TAXSIM calculator. 


\section{(b) TRA86}

\begin{tabular}{|c|c|c|c|c|c|c|c|c|c|c|c|}
\hline \multirow{5}{*}{$\begin{array}{l}\text { data year: } \\
\text { adjusted to: } \\
\text { policy year }\end{array}$} & \multirow{3}{*}{$\begin{array}{r}1986 \\
1986\end{array}$} & \multirow{2}{*}{$\begin{array}{l}1988 \\
1986\end{array}$} & \multirow{2}{*}{$\begin{array}{l}1986 \\
1988\end{array}$} & \multirow[t]{2}{*}{1988} & \multirow[b]{2}{*}{ Total } & \multicolumn{2}{|c|}{ Decomp. I } & \multicolumn{2}{|c|}{ Decomp. II } & \multicolumn{2}{|c|}{ Shapley-Dec. } \\
\hline & & & & & & $\mathrm{PE}$ & $\mathrm{OE}$ & $\mathrm{PE}$ & $\mathrm{OE}$ & $\mathrm{PE}$ & $\mathrm{OE}$ \\
\hline & & 1986 & 1988 & 1988 & change & & & & & Mean & Mean \\
\hline & & & & & & & & & & $(4)-(2)$ & $(2)-(1)$ \\
\hline & $(1)$ & $(2)$ & $(3)$ & $(4)$ & $(4)-(1)$ & $(4)-(2)$ & $(2)-(1)$ & $(3)-(1)$ & $(4)-(3)$ & $(3)-(1)$ & $(4)-(3)$ \\
\hline \multicolumn{12}{|c|}{ Average tax rates } \\
\hline P20-40 & 14.7 & 15.0 & 14.3 & 14.3 & -0.4 & -0.7 & 0.3 & -0.4 & 0.0 & -0.5 & 0.2 \\
\hline P $40-60$ & 21.3 & 22.0 & 21.5 & 21.2 & -0.1 & -0.8 & 0.7 & 0.1 & -0.3 & -0.3 & 0.2 \\
\hline P60-80 & 25.9 & 26.7 & 26.0 & 25.6 & -0.2 & -1.1 & 0.9 & 0.2 & -0.4 & -0.5 & 0.2 \\
\hline P $80-90$ & 28.2 & 30.6 & 27.9 & 27.9 & -0.4 & -2.7 & 2.4 & -0.3 & -0.1 & -1.5 & 1.1 \\
\hline P90-95 & 29.5 & 33.8 & 29.5 & 29.3 & -0.2 & -4.5 & 4.3 & 0.1 & -0.2 & -2.2 & 2.1 \\
\hline P95-99 & 31.0 & 35.8 & 31.0 & 30.1 & -0.9 & -5.8 & 4.9 & 0.0 & -0.9 & -2.9 & 2.0 \\
\hline P99-99.5 & 33.7 & 36.5 & 33.4 & 30.5 & -3.2 & -6.0 & 2.8 & -0.2 & -3.0 & -3.1 & -0.1 \\
\hline P99.5-99.9 & 38.1 & 39.3 & 36.4 & 30.5 & -7.5 & -8.7 & 1.2 & -1.7 & -5.8 & -5.2 & -2.3 \\
\hline P99.9-99.99 & 43.4 & 42.7 & 37.3 & 30.1 & -13.4 & -12.6 & -0.7 & -6.1 & -7.2 & -9.4 & -4.0 \\
\hline P99.99-100 & 45.8 & 43.4 & 39.8 & 29.2 & -16.6 & -14.3 & -2.4 & -6.0 & -10.6 & -10.1 & -6.5 \\
\hline Top $20 \%$ & 31.3 & 34.9 & 30.6 & 29.3 & -2.1 & -5.6 & 3.6 & -0.7 & -1.4 & -3.2 & 1.1 \\
\hline Top $10 \%$ & 32.9 & 36.8 & 32.0 & 29.9 & -3.0 & -6.9 & 3.9 & -0.9 & -2.1 & -3.9 & 0.9 \\
\hline Top 5\% & 34.5 & 38.0 & 33.2 & 30.1 & -4.4 & -7.9 & 3.5 & -1.3 & -3.1 & -4.6 & 0.2 \\
\hline Top 1\% & 39.0 & 40.0 & 36.1 & 30.2 & -8.8 & -9.9 & 1.0 & -2.9 & -5.9 & -6.4 & -2.4 \\
\hline \multicolumn{12}{|c|}{ Post-tax income shares } \\
\hline P20-40 & 7.8 & 7.8 & 7.8 & 7.5 & -0.2 & -0.3 & 0.0 & 0.0 & -0.3 & -0.1 & -0.1 \\
\hline $\mathrm{P} 40-60$ & 14.8 & 14.4 & 14.7 & 13.9 & -0.9 & -0.5 & -0.3 & -0.1 & -0.8 & -0.3 & -0.6 \\
\hline P60-80 & 24.6 & 23.7 & 24.5 & 23.0 & -1.6 & -0.7 & -0.9 & -0.1 & -1.5 & -0.4 & -1.2 \\
\hline P $80-90$ & 18.0 & 17.1 & 18.1 & 17.0 & -1.0 & -0.2 & -0.9 & 0.0 & -1.1 & -0.1 & -1.0 \\
\hline P90-95 & 11.6 & 10.9 & 11.6 & 11.1 & -0.5 & 0.2 & -0.7 & -0.0 & -0.5 & 0.1 & -0.6 \\
\hline P95-99 & 13.1 & 12.6 & 13.0 & 13.1 & -0.0 & 0.4 & -0.5 & -0.1 & 0.0 & 0.2 & -0.2 \\
\hline P99-99.5 & 2.6 & 2.9 & 2.6 & 3.1 & 0.4 & 0.1 & 0.3 & 0.0 & 0.4 & 0.1 & 0.4 \\
\hline P99.5-99.9 & 3.4 & 4.3 & 3.5 & 4.7 & 1.2 & 0.4 & 0.9 & 0.1 & 1.1 & 0.2 & 1.0 \\
\hline P99.9-99.99 & 1.7 & 2.9 & 1.9 & 3.3 & 1.6 & 0.4 & 1.2 & 0.2 & 1.4 & 0.3 & 1.3 \\
\hline P99.99-100 & 1.0 & 1.9 & 1.1 & 2.2 & 1.2 & 0.3 & 0.9 & 0.1 & 1.1 & 0.2 & 1.0 \\
\hline Top $20 \%$ & 51.5 & 52.7 & 51.8 & 54.3 & 2.8 & 1.6 & 1.2 & 0.3 & 2.5 & 1.0 & 1.9 \\
\hline Top $10 \%$ & 33.5 & 35.5 & 33.8 & 37.3 & 3.9 & 1.8 & 2.1 & 0.3 & 3.6 & 1.1 & 2.8 \\
\hline Top 5\% & 21.8 & 24.6 & 22.2 & 26.2 & 4.4 & 1.6 & 2.8 & 0.3 & 4.1 & 1.0 & 3.4 \\
\hline Top $1 \%$ & 8.8 & 12.0 & 9.1 & 13.2 & 4.4 & 1.2 & 3.3 & 0.4 & 4.0 & 0.8 & 3.6 \\
\hline
\end{tabular}

Note: PE: Policy effect. OE: Other effect. Average tax rates include federal and state level income and payroll taxes. Uprating according to the level of price inflation. Sources: Own calculations based on SOI IRS income tax return data and NBER TAXSIM calculator. 
(c) OBRA90/OBRA93

\begin{tabular}{|c|c|c|c|c|c|c|c|c|c|c|c|}
\hline \multirow{5}{*}{$\begin{array}{l}\text { data year: } \\
\text { adjusted to: } \\
\text { policy year }\end{array}$} & \multirow{3}{*}{$\begin{array}{r}1989 \\
1989\end{array}$} & \multirow{2}{*}{$\begin{array}{l}1994 \\
1989\end{array}$} & \multirow{2}{*}{$\begin{array}{l}1989 \\
1994\end{array}$} & \multirow[t]{2}{*}{1994} & \multirow[b]{2}{*}{ Total } & \multicolumn{2}{|c|}{ Decomp. I } & \multicolumn{2}{|c|}{ Decomp. II } & \multicolumn{2}{|c|}{ Shapley-Dec. } \\
\hline & & & & & & $\mathrm{PE}$ & $\mathrm{OE}$ & $\mathrm{PE}$ & $\mathrm{OE}$ & $\mathrm{PE}$ & $\mathrm{OE}$ \\
\hline & & 1989 & 1994 & 1994 & change & & & & & Mean & Mean \\
\hline & & & & & & & & & & $(4)-(2)$ & $(2)-(1)$ \\
\hline & $(1)$ & $(2)$ & $(3)$ & $(4)$ & $(4)-(1)$ & $(4)-(2)$ & $(2)-(1)$ & $(3)-(1)$ & $(4)-(3)$ & $(3)-(1)$ & $(4)-(3)$ \\
\hline \multicolumn{12}{|c|}{ Average tax rates } \\
\hline P20-40 & 14.4 & 13.3 & 10.9 & 9.8 & -4.5 & -3.4 & -1.1 & -3.4 & -1.1 & -3.4 & -1.1 \\
\hline P40-60 & 21.3 & 20.5 & 20.7 & 19.9 & -1.4 & -0.6 & -0.8 & -0.5 & -0.9 & -0.6 & -0.8 \\
\hline P60-80 & 25.7 & 25.9 & 25.9 & 26.1 & 0.5 & 0.3 & 0.2 & 0.3 & 0.2 & 0.3 & 0.2 \\
\hline P80-90 & 27.9 & 28.3 & 28.2 & 28.6 & 0.7 & 0.3 & 0.4 & 0.3 & 0.4 & 0.3 & 0.4 \\
\hline P90-95 & 29.6 & 30.0 & 30.1 & 30.5 & 1.0 & 0.6 & 0.4 & 0.5 & 0.4 & 0.5 & 0.4 \\
\hline P95-99 & 30.1 & 30.9 & 31.2 & 31.9 & 1.8 & 1.0 & 0.8 & 1.0 & 0.8 & 1.0 & 0.8 \\
\hline P99-99.5 & 30.3 & 31.3 & 33.0 & 33.9 & 3.6 & 2.6 & 1.0 & 2.6 & 1.0 & 2.6 & 1.0 \\
\hline P99.5-99.9 & 30.3 & 31.3 & 36.7 & 37.3 & 7.0 & 6.1 & 0.9 & 6.4 & 0.6 & 6.2 & 0.8 \\
\hline Р99.9-99.99 & 29.8 & 30.2 & 40.0 & 40.0 & 10.2 & 9.8 & 0.5 & 10.2 & -0.0 & 10.0 & 0.2 \\
\hline P99.99-100 & 29.3 & 28.9 & 40.8 & 39.8 & 10.5 & 10.8 & -0.3 & 11.5 & -1.0 & 11.2 & -0.7 \\
\hline Top $20 \%$ & 29.3 & 29.9 & 31.5 & 31.9 & 2.6 & 2.0 & 0.6 & 2.2 & 0.4 & 2.1 & 0.5 \\
\hline Top $10 \%$ & 29.9 & 30.6 & 33.0 & 33.4 & 3.5 & 2.8 & 0.6 & 3.0 & 0.4 & 2.9 & 0.5 \\
\hline Top 5\% & 30.1 & 30.8 & 34.1 & 34.6 & 4.5 & 3.8 & 0.7 & 4.1 & 0.4 & 3.9 & 0.6 \\
\hline Top $1 \%$ & 30.0 & 30.7 & 37.2 & 37.4 & 7.4 & 6.7 & 0.7 & 7.2 & 0.2 & 7.0 & 0.4 \\
\hline \multicolumn{12}{|c|}{ Post-tax income shares } \\
\hline P20-40 & 7.6 & 7.2 & 8.0 & 7.5 & -0.1 & 0.3 & -0.4 & 0.3 & -0.4 & 0.3 & -0.4 \\
\hline P $40-60$ & 13.9 & 13.5 & 14.1 & 13.7 & -0.1 & 0.2 & -0.4 & 0.2 & -0.4 & 0.2 & -0.4 \\
\hline $\mathrm{P} 60-80$ & 23.1 & 22.7 & 23.2 & 22.8 & -0.2 & 0.1 & -0.3 & 0.1 & -0.4 & 0.1 & -0.4 \\
\hline P $80-90$ & 17.1 & 17.4 & 17.3 & 17.5 & 0.4 & 0.1 & 0.3 & 0.1 & 0.2 & 0.1 & 0.2 \\
\hline P90-95 & 11.2 & 11.5 & 11.3 & 11.6 & 0.3 & 0.0 & 0.3 & 0.1 & 0.2 & 0.1 & 0.3 \\
\hline P95-99 & 13.3 & 13.8 & 13.3 & 13.8 & 0.5 & 0.0 & 0.5 & 0.0 & 0.5 & 0.0 & 0.5 \\
\hline P99-99.5 & 3.1 & 3.1 & 3.0 & 3.1 & 0.0 & -0.0 & 0.1 & -0.1 & 0.1 & -0.0 & 0.1 \\
\hline P99.5-99.9 & 4.5 & 4.5 & 4.1 & 4.2 & -0.3 & -0.3 & 0.0 & -0.3 & 0.0 & -0.3 & 0.0 \\
\hline P99.9-99.99 & 3.0 & 2.9 & 2.6 & 2.5 & -0.5 & -0.4 & -0.1 & -0.4 & -0.1 & -0.4 & -0.1 \\
\hline P99.99-100 & 1.9 & 1.8 & 1.6 & 1.5 & -0.4 & -0.2 & -0.1 & -0.3 & -0.1 & -0.3 & -0.1 \\
\hline Top $20 \%$ & 54.1 & 54.9 & 53.3 & 54.1 & 0.0 & -0.8 & 0.8 & -0.9 & 0.9 & -0.8 & 0.9 \\
\hline Top $10 \%$ & 37.0 & 37.5 & 36.0 & 36.7 & -0.3 & -0.9 & 0.5 & -1.0 & 0.6 & -0.9 & 0.6 \\
\hline Top 5\% & 25.8 & 26.1 & 24.7 & 25.1 & -0.6 & -1.0 & 0.3 & -1.0 & 0.4 & -1.0 & 0.4 \\
\hline Top $1 \%$ & 12.5 & 12.3 & 11.4 & 11.4 & -1.1 & -1.0 & -0.2 & -1.1 & -0.1 & -1.0 & -0.1 \\
\hline
\end{tabular}

Note: PE: Policy effect. OE: Other effect. Average tax rates include federal and state level income and payroll taxes. Uprating according to the level of price inflation. Sources: Own calculations based on SOI IRS income tax return data and NBER TAXSIM calculator. 
(d) EGTRRA01/JGTRRA03

\begin{tabular}{|c|c|c|c|c|c|c|c|c|c|c|c|}
\hline \multirow{5}{*}{$\begin{array}{l}\text { data year: } \\
\text { adjusted to: } \\
\text { policy year }\end{array}$} & \multirow{3}{*}{$\begin{array}{l}2000 \\
2000\end{array}$} & \multirow{2}{*}{$\begin{array}{l}2004 \\
2000\end{array}$} & \multirow{2}{*}{$\begin{array}{l}2000 \\
2004\end{array}$} & \multirow[t]{2}{*}{2004} & \multirow[b]{2}{*}{ Total } & \multicolumn{2}{|c|}{ Decomp. I } & \multicolumn{2}{|c|}{ Decomp. II } & \multicolumn{2}{|c|}{ Shapley-Dec. } \\
\hline & & & & & & $\mathrm{PE}$ & $\mathrm{OE}$ & $\mathrm{PE}$ & $\mathrm{OE}$ & $\mathrm{PE}$ & $\mathrm{OE}$ \\
\hline & & 2000 & 2004 & 2004 & change & & & & & Mean & Mean \\
\hline & & & & & & & & & & $(4)-(2)$ & $(2)-(1)$ \\
\hline & $(1)$ & $(2)$ & $(3)$ & $(4)$ & $(4)-(1)$ & $(4)-(2)$ & $(2)-(1)$ & $(3)-(1)$ & $(4)-(3)$ & $(3)-(1)$ & $(4)-(3)$ \\
\hline \multicolumn{12}{|c|}{ Average tax rates } \\
\hline P20-40 & 10.5 & 4.4 & 8.7 & 2.3 & -8.2 & -2.1 & -6.1 & -1.8 & -6.4 & -2.0 & -6.2 \\
\hline P40-60 & 20.9 & 19.3 & 18.6 & 16.7 & -4.2 & -2.6 & -1.6 & -2.3 & -1.8 & -2.5 & -1.7 \\
\hline P60-80 & 25.9 & 25.3 & 23.9 & 23.2 & -2.7 & -2.1 & -0.6 & -2.0 & -0.7 & -2.1 & -0.7 \\
\hline P80-90 & 28.5 & 28.0 & 26.2 & 25.6 & -2.9 & -2.4 & -0.5 & -2.3 & -0.6 & -2.3 & -0.5 \\
\hline P90-95 & 30.6 & 30.3 & 28.2 & 27.7 & -2.9 & -2.6 & -0.3 & -2.4 & -0.5 & -2.5 & -0.4 \\
\hline P95-99 & 31.9 & 31.6 & 29.8 & 29.2 & -2.7 & -2.3 & -0.4 & -2.2 & -0.5 & -2.3 & -0.4 \\
\hline P99-99.5 & 33.9 & 34.1 & 31.7 & 31.8 & -2.1 & -2.4 & 0.3 & -2.2 & 0.1 & -2.3 & 0.2 \\
\hline P99.5-99.9 & 35.8 & 36.1 & 32.6 & 32.6 & -3.2 & -3.5 & 0.3 & -3.2 & -0.0 & -3.4 & 0.2 \\
\hline Р99.9-99.99 & 36.6 & 37.4 & 32.5 & 32.9 & -3.7 & -4.6 & 0.9 & -4.0 & 0.3 & -4.3 & 0.6 \\
\hline P99.99-100 & 37.2 & 37.0 & 32.8 & 31.8 & -5.5 & -5.2 & -0.3 & -4.4 & -1.0 & -4.8 & -0.7 \\
\hline Top $20 \%$ & 32.1 & 31.7 & 29.5 & 28.9 & -3.2 & -2.8 & -0.4 & -2.5 & -0.6 & -2.7 & -0.5 \\
\hline Top $10 \%$ & 33.3 & 33.1 & 30.6 & 30.1 & -3.2 & -3.0 & -0.2 & -2.7 & -0.5 & -2.8 & -0.4 \\
\hline Top 5\% & 34.2 & 34.0 & 31.4 & 30.9 & -3.2 & -3.1 & -0.1 & -2.8 & -0.4 & -2.9 & -0.3 \\
\hline Top $1 \%$ & 35.9 & 36.2 & 32.5 & 32.3 & -3.5 & -3.8 & 0.3 & -3.4 & -0.2 & -3.6 & 0.1 \\
\hline \multicolumn{12}{|c|}{ Post-tax income shares } \\
\hline P20-40 & 7.3 & 7.2 & 7.2 & 7.1 & -0.2 & -0.1 & -0.1 & -0.1 & -0.1 & -0.1 & -0.1 \\
\hline P40-60 & 12.4 & 12.5 & 12.4 & 12.4 & -0.0 & -0.1 & 0.0 & -0.1 & 0.0 & -0.1 & 0.0 \\
\hline $\mathrm{P} 60-80$ & 20.5 & 21.0 & 20.4 & 20.9 & 0.3 & -0.1 & 0.5 & -0.1 & 0.4 & -0.1 & 0.5 \\
\hline P $80-90$ & 15.8 & 16.5 & 15.8 & 16.4 & 0.6 & -0.1 & 0.6 & -0.0 & 0.6 & -0.0 & 0.6 \\
\hline P90-95 & 10.9 & 11.2 & 10.9 & 11.2 & 0.4 & 0.0 & 0.3 & 0.0 & 0.3 & 0.0 & 0.3 \\
\hline P95-99 & 14.2 & 14.2 & 14.2 & 14.2 & 0.0 & -0.0 & 0.0 & 0.0 & -0.0 & 0.0 & 0.0 \\
\hline P99-99.5 & 3.6 & 3.4 & 3.6 & 3.4 & -0.2 & 0.0 & -0.2 & 0.0 & -0.2 & 0.0 & -0.2 \\
\hline P99.5-99.9 & 5.6 & 5.1 & 5.7 & 5.2 & -0.3 & 0.1 & -0.4 & 0.1 & -0.4 & 0.1 & -0.4 \\
\hline P99.9-99.99 & 4.5 & 3.8 & 4.6 & 3.9 & -0.5 & 0.1 & -0.7 & 0.1 & -0.6 & 0.1 & -0.6 \\
\hline P99.99-100 & 2.8 & 2.7 & 2.9 & 2.8 & -0.0 & 0.1 & -0.2 & 0.1 & -0.1 & 0.1 & -0.1 \\
\hline Top $20 \%$ & 57.4 & 56.9 & 57.7 & 57.2 & -0.2 & 0.3 & -0.4 & 0.3 & -0.4 & 0.3 & -0.4 \\
\hline Top $10 \%$ & 41.5 & 40.5 & 41.8 & 40.8 & -0.7 & 0.3 & -1.1 & 0.3 & -1.0 & 0.3 & -1.0 \\
\hline Top 5\% & 30.7 & 29.3 & 30.9 & 29.6 & -1.1 & 0.3 & -1.4 & 0.3 & -1.4 & 0.3 & -1.4 \\
\hline Top $1 \%$ & 16.5 & 15.1 & 16.8 & 15.4 & -1.1 & 0.3 & -1.4 & 0.3 & -1.4 & 0.3 & -1.4 \\
\hline
\end{tabular}

Note: PE: Policy effect. OE: Other effect. Average tax rates include federal and state level income and payroll taxes. Uprating according to the level of price inflation. Sources: Own calculations based on SOI IRS income tax return data and NBER TAXSIM calculator. 
Table 4: Decomposition results for major tax reforms including indirect policy effects (a) ERTA81

\begin{tabular}{|c|c|c|c|c|c|c|c|c|c|c|c|}
\hline \multirow{3}{*}{$\begin{array}{l}\text { data year: } \\
\text { policy year: }\end{array}$} & \multirow{3}{*}{$\begin{array}{l}1981 \\
1981 \\
(1) \\
\end{array}$} & \multirow{3}{*}{$\begin{array}{l}1984 \\
1984 \\
(2)\end{array}$} & \multirow{3}{*}{$\begin{array}{l}\text { Total } \\
\text { change } \\
(3)\end{array}$} & \multicolumn{2}{|c|}{$\mathrm{ETI}=0$} & \multicolumn{2}{|c|}{$\mathrm{ETI}=0.2$} & \multicolumn{2}{|c|}{$\mathrm{ETI}=0.5$} & \multicolumn{2}{|c|}{$\mathrm{ETI}=1.0$} \\
\hline & & & & $\mathrm{PE}$ & $\mathrm{OE}$ & IPE & $\mathrm{RE}$ & IPE & $\mathrm{RE}$ & IPE & $\mathrm{RE}$ \\
\hline & & & & $(4)$ & $(5)$ & $(6)$ & $(7)$ & (8) & $(9)$ & $(10)$ & $(11)$ \\
\hline \multicolumn{12}{|c|}{ Average tax rates } \\
\hline P20-40 & 15.1 & 14.9 & -0.3 & 1.1 & -1.3 & -0.2 & -1.1 & -0.5 & -0.8 & -0.9 & -0.4 \\
\hline $\mathrm{P} 40-60$ & 22.3 & 21.2 & -1.2 & -0.1 & -1.1 & 0.1 & -1.2 & 0.1 & -1.2 & 0.3 & -1.4 \\
\hline P60-80 & 26.9 & 25.5 & -1.4 & -0.7 & -0.8 & 0.0 & -0.8 & 0.1 & -0.8 & 0.2 & -0.9 \\
\hline P $80-90$ & 29.4 & 27.9 & -1.5 & -0.9 & -0.6 & 0.0 & -0.6 & 0.1 & -0.7 & 0.1 & -0.7 \\
\hline P90-95 & 30.6 & 28.9 & -1.7 & -1.1 & -0.6 & 0.1 & -0.6 & 0.2 & -0.7 & 0.3 & -0.9 \\
\hline P95-99 & 32.5 & 30.0 & -2.5 & -1.8 & -0.7 & 0.1 & -0.8 & 0.2 & -0.9 & 0.4 & -1.1 \\
\hline P99-99.5 & 36.0 & 32.4 & -3.7 & -2.8 & -0.9 & 0.1 & -1.0 & 0.2 & -1.1 & 0.4 & -1.3 \\
\hline P99.5-99.9 & 39.8 & 35.9 & -3.9 & -3.3 & -0.5 & 0.0 & -0.6 & 0.1 & -0.7 & 0.2 & -0.8 \\
\hline P99.9-99.99 & 44.5 & 42.2 & -2.3 & -3.9 & 1.6 & 0.1 & 1.5 & 0.3 & 1.4 & 0.5 & 1.1 \\
\hline P99.99-100 & 46.9 & 44.5 & -2.4 & -5.6 & 3.1 & 0.2 & 2.9 & 0.6 & 2.5 & 1.2 & 2.0 \\
\hline Top $20 \%$ & 32.2 & 30.4 & -1.8 & -1.6 & -0.2 & 0.0 & -0.3 & 0.1 & -0.3 & 0.2 & -0.5 \\
\hline Top 10\% & 33.7 & 31.6 & -2.1 & -2.0 & -0.1 & 0.1 & -0.2 & 0.1 & -0.3 & 0.3 & -0.4 \\
\hline Top 5\% & 35.5 & 33.0 & -2.4 & -2.4 & 0.0 & 0.0 & -0.0 & 0.1 & -0.1 & 0.2 & -0.2 \\
\hline Top $1 \%$ & 40.1 & 37.2 & -2.9 & -3.5 & 0.6 & 0.0 & 0.6 & 0.0 & 0.5 & 0.1 & 0.5 \\
\hline \multicolumn{12}{|c|}{ Post-tax income shares } \\
\hline P20-40 & 8.6 & 8.0 & -0.6 & -0.2 & -0.4 & -0.1 & -0.3 & -0.2 & -0.2 & -0.3 & -0.1 \\
\hline $\mathrm{P} 40-60$ & 15.7 & 15.1 & -0.7 & -0.2 & -0.5 & -0.0 & -0.4 & -0.1 & -0.4 & -0.1 & -0.3 \\
\hline P60-80 & 25.4 & 24.9 & -0.4 & -0.1 & -0.3 & -0.0 & -0.3 & -0.0 & -0.3 & -0.0 & -0.3 \\
\hline P80-90 & 18.0 & 18.1 & 0.2 & 0.0 & 0.1 & 0.0 & 0.1 & 0.0 & 0.1 & 0.0 & 0.1 \\
\hline P90-95 & 11.3 & 11.6 & 0.3 & 0.1 & 0.2 & 0.0 & 0.2 & 0.0 & 0.2 & 0.1 & 0.2 \\
\hline P95-99 & 12.1 & 12.8 & 0.6 & 0.2 & 0.5 & 0.0 & 0.4 & 0.1 & 0.4 & 0.1 & 0.3 \\
\hline P99-99.5 & 2.3 & 2.5 & 0.2 & 0.1 & 0.1 & 0.0 & 0.1 & 0.0 & 0.1 & 0.0 & 0.1 \\
\hline P99.5-99.9 & 2.7 & 3.0 & 0.4 & 0.1 & 0.3 & 0.0 & 0.3 & 0.0 & 0.2 & 0.1 & 0.2 \\
\hline P99.9-99.99 & 1.2 & 1.6 & 0.3 & 0.1 & 0.3 & 0.0 & 0.3 & 0.0 & 0.2 & 0.1 & 0.2 \\
\hline P99.99-100 & 0.5 & 0.8 & 0.3 & 0.0 & 0.3 & 0.0 & 0.3 & 0.0 & 0.2 & 0.0 & 0.2 \\
\hline Top $20 \%$ & 48.1 & 50.4 & 2.3 & 0.5 & 1.8 & 0.1 & 1.7 & 0.2 & 1.6 & 0.4 & 1.4 \\
\hline Top $10 \%$ & 30.1 & 32.3 & 2.2 & 0.5 & 1.7 & 0.1 & 1.6 & 0.2 & 1.5 & 0.4 & 1.3 \\
\hline Top 5\% & 18.8 & 20.7 & 1.9 & 0.5 & 1.4 & 0.1 & 1.3 & 0.2 & 1.2 & 0.3 & 1.1 \\
\hline Top 1\% & 6.7 & 7.9 & 1.2 & 0.3 & 0.9 & 0.0 & 0.9 & 0.1 & 0.8 & 0.2 & 0.7 \\
\hline
\end{tabular}

Note: PE: Policy effect. IPE: Indirect policy effect. OE: Other effect. RE: Residual effect. ETI: Elasticity of taxable income. Results for $\mathrm{ETI}=0$ correspond to the baseline results. If $\mathrm{ETI}=0$ : Total change $=\mathrm{PE}+\mathrm{OE}$. If ETI $>0: \mathrm{PE}$ is equal to (4). Total change $=\mathrm{PE}+$ $\mathrm{IPE}+\mathrm{RE}$. Average tax rates include federal and state level income and payroll taxes. Uprating according to the level of price inflation. Sources: Own calculations based on SOI IRS income tax return data and NBER TAXSIM calculator. 
(b) TRA86

\begin{tabular}{|c|c|c|c|c|c|c|c|c|c|c|c|}
\hline \multirow{3}{*}{$\begin{array}{l}\text { data year: } \\
\text { policy year: }\end{array}$} & \multirow{3}{*}{$\begin{array}{l}1986 \\
1986 \\
(1)\end{array}$} & \multirow{3}{*}{$\begin{array}{l}1988 \\
1988 \\
(2)\end{array}$} & \multirow{3}{*}{$\begin{array}{l}\text { Total } \\
\text { change } \\
(3)\end{array}$} & \multicolumn{2}{|c|}{$\mathrm{ETI}=0$} & \multicolumn{2}{|c|}{$\mathrm{ETI}=0.2$} & \multicolumn{2}{|c|}{$\mathrm{ETI}=0.5$} & \multicolumn{2}{|c|}{$\mathrm{ETI}=1.0$} \\
\hline & & & & $\mathrm{PE}$ & $\mathrm{OE}$ & IPE & $\mathrm{RE}$ & IPE & $\mathrm{RE}$ & IPE & $\mathrm{RE}$ \\
\hline & & & & (4) & $(5)$ & (6) & $(7)$ & (8) & (9) & (10) & (11) \\
\hline \multicolumn{12}{|c|}{ Average tax rates } \\
\hline P20-40 & 14.7 & 14.3 & -0.4 & -0.5 & 0.2 & 0.0 & 0.2 & 0.0 & 0.1 & 0.1 & 0.1 \\
\hline $\mathrm{P} 40-60$ & 21.3 & 21.2 & -0.1 & -0.3 & 0.2 & 0.0 & 0.2 & 0.0 & 0.2 & 0.0 & 0.2 \\
\hline P60-80 & 25.9 & 25.6 & -0.2 & -0.5 & 0.2 & 0.0 & 0.2 & 0.0 & 0.2 & 0.1 & 0.2 \\
\hline P80-90 & 28.2 & 27.9 & -0.4 & -1.5 & 1.1 & 0.1 & 1.0 & 0.3 & 0.8 & 0.6 & 0.6 \\
\hline Р90-95 & 29.5 & 29.3 & -0.2 & -2.2 & 2.1 & 0.3 & 1.7 & 0.8 & 1.3 & 1.2 & 0.8 \\
\hline P95-99 & 31.0 & 30.1 & -0.9 & -2.9 & 2.0 & 0.2 & 1.7 & 0.6 & 1.4 & 1.0 & 1.0 \\
\hline P99-99.5 & 33.7 & 30.5 & -3.2 & -3.1 & -0.1 & 0.1 & -0.1 & 0.2 & -0.3 & 0.4 & -0.4 \\
\hline P99.5-99.9 & 38.1 & 30.5 & -7.5 & -5.2 & -2.3 & 0.4 & -2.7 & 0.9 & -3.2 & 1.7 & -4.1 \\
\hline P99.9-99.99 & 43.4 & 30.1 & -13.4 & -9.4 & -4.0 & 0.2 & -4.2 & 0.6 & -4.6 & 1.2 & -5.2 \\
\hline P99.99-100 & 45.8 & 29.2 & -16.6 & -10.1 & -6.5 & 0.7 & -7.2 & 1.8 & -8.3 & 3.6 & -10.0 \\
\hline Top 20\% & 31.3 & 29.3 & -2.1 & -3.2 & 1.1 & 0.1 & 1.0 & 0.2 & 0.9 & 0.4 & 0.7 \\
\hline Top $10 \%$ & 32.9 & 29.9 & -3.0 & -3.9 & 0.9 & 0.1 & 0.9 & 0.2 & 0.8 & 0.3 & 0.6 \\
\hline Top $5 \%$ & 34.5 & 30.1 & -4.4 & -4.6 & 0.2 & 0.1 & 0.2 & 0.1 & 0.1 & 0.3 & -0.1 \\
\hline Top $1 \%$ & 39.0 & 30.2 & -8.8 & -6.4 & -2.4 & 0.3 & -2.7 & 0.7 & -3.1 & 1.4 & -3.8 \\
\hline \multicolumn{12}{|c|}{ Post-tax income shares } \\
\hline P20-40 & 7.8 & 7.5 & -0.2 & -0.1 & -0.1 & -0.0 & -0.1 & -0.0 & -0.1 & -0.0 & -0.1 \\
\hline P40-60 & 14.8 & 13.9 & -0.9 & -0.3 & -0.6 & -0.0 & -0.6 & -0.0 & -0.5 & -0.1 & -0.5 \\
\hline P60-80 & 24.6 & 23.0 & -1.6 & -0.4 & -1.2 & -0.1 & -1.1 & -0.2 & -1.0 & -0.3 & -0.9 \\
\hline P80-90 & 18.0 & 17.0 & -1.0 & -0.1 & -1.0 & -0.0 & -1.0 & -0.1 & -0.9 & -0.1 & -0.9 \\
\hline P90-95 & 11.6 & 11.1 & -0.5 & 0.1 & -0.6 & 0.0 & -0.6 & 0.1 & -0.7 & 0.2 & -0.8 \\
\hline P95-99 & 13.1 & 13.1 & -0.0 & 0.2 & -0.2 & 0.0 & -0.2 & 0.1 & -0.3 & 0.1 & -0.3 \\
\hline P99-99.5 & 2.6 & 3.1 & 0.4 & 0.1 & 0.4 & 0.0 & 0.3 & 0.0 & 0.3 & 0.0 & 0.3 \\
\hline P99.5-99.9 & 3.4 & 4.7 & 1.2 & 0.2 & 1.0 & 0.1 & 0.9 & 0.1 & 0.9 & 0.2 & 0.8 \\
\hline P99.9-99.99 & 1.7 & 3.3 & 1.6 & 0.3 & 1.3 & 0.1 & 1.3 & 0.2 & 1.2 & 0.3 & 1.0 \\
\hline P99.99-100 & 1.0 & 2.2 & 1.2 & 0.2 & 1.0 & 0.1 & 0.9 & 0.1 & 0.8 & 0.2 & 0.8 \\
\hline Top $20 \%$ & 51.5 & 54.3 & 2.8 & 1.0 & 1.9 & 0.1 & 1.8 & 0.2 & 1.7 & 0.4 & 1.5 \\
\hline Top $10 \%$ & 33.5 & 37.3 & 3.9 & 1.1 & 2.8 & 0.1 & 2.7 & 0.4 & 2.5 & 0.7 & 2.1 \\
\hline Top 5\% & 21.8 & 26.2 & 4.4 & 1.0 & 3.4 & 0.2 & 3.2 & 0.5 & 2.9 & 1.0 & 2.5 \\
\hline Top $1 \%$ & 8.8 & 13.2 & 4.4 & 0.8 & 3.6 & 0.2 & 3.5 & 0.5 & 3.2 & 0.7 & 2.9 \\
\hline
\end{tabular}

Note: PE: Policy effect. IPE: Indirect policy effect. OE: Other effect. RE: Residual effect. ETI: Elasticity of taxable income. Results for $\mathrm{ETI}=0$ correspond to the baseline results. If $\mathrm{ETI}=0$ : Total change $=\mathrm{PE}+\mathrm{OE}$. If $\mathrm{ETI}>0: \mathrm{PE}$ is equal to (4). Total change $=\mathrm{PE}+$ $\mathrm{IPE}+\mathrm{RE}$. Average tax rates include federal and state level income and payroll taxes. Uprating according to the level of price inflation. Sources: Own calculations based on SOI IRS income tax return data and NBER TAXSIM calculator. 
(c) OBRA90/OBRA93

\begin{tabular}{|c|c|c|c|c|c|c|c|c|c|c|c|}
\hline \multirow{3}{*}{$\begin{array}{l}\text { data year: } \\
\text { policy year: }\end{array}$} & \multirow{3}{*}{$\begin{array}{l}1989 \\
1989 \\
(1)\end{array}$} & \multirow{3}{*}{$\begin{array}{l}1994 \\
1994 \\
(2)\end{array}$} & \multirow{3}{*}{$\begin{array}{l}\text { Total } \\
\text { change } \\
(3)\end{array}$} & \multicolumn{2}{|c|}{$\mathrm{ETI}=0$} & \multicolumn{2}{|c|}{$\mathrm{ETI}=0.2$} & \multicolumn{2}{|c|}{$\mathrm{ETI}=0.5$} & \multicolumn{2}{|c|}{$\mathrm{ETI}=1.0$} \\
\hline & & & & $\mathrm{PE}$ & $\mathrm{OE}$ & IPE & $\mathrm{RE}$ & IPE & $\mathrm{RE}$ & IPE & $\mathrm{RE}$ \\
\hline & & & & (4) & $(5)$ & (6) & (7) & (8) & (9) & (10) & (11) \\
\hline \multicolumn{12}{|c|}{ Average tax rates } \\
\hline P20-40 & 14.4 & 9.8 & -4.5 & -3.4 & -1.1 & 0.6 & -1.7 & 0.9 & -2.0 & 1.2 & -2.3 \\
\hline $\mathrm{P} 40-60$ & 21.3 & 19.9 & -1.4 & -0.6 & -0.8 & 0.2 & -1.1 & 0.4 & -1.2 & 0.5 & -1.3 \\
\hline P60-80 & 25.7 & 26.1 & 0.5 & 0.3 & 0.2 & -0.0 & 0.2 & -0.0 & 0.2 & -0.0 & 0.2 \\
\hline P80-90 & 27.9 & 28.6 & 0.7 & 0.3 & 0.4 & -0.0 & 0.4 & -0.0 & 0.4 & -0.0 & 0.4 \\
\hline P90-95 & 29.6 & 30.5 & 1.0 & 0.5 & 0.4 & -0.0 & 0.4 & -0.0 & 0.4 & -0.1 & 0.5 \\
\hline P95-99 & 30.1 & 31.9 & 1.8 & 1.0 & 0.8 & -0.0 & 0.8 & -0.0 & 0.8 & -0.0 & 0.8 \\
\hline P99-99.5 & 30.3 & 33.9 & 3.6 & 2.6 & 1.0 & -0.2 & 1.1 & -0.3 & 1.3 & -0.5 & 1.4 \\
\hline P99.5-99.9 & 30.3 & 37.3 & 7.0 & 6.2 & 0.8 & -0.2 & 0.9 & -0.3 & 1.1 & -0.4 & 1.2 \\
\hline P99.9-99.99 & 29.8 & 40.0 & 10.2 & 10.0 & 0.2 & -0.3 & 0.5 & -0.5 & 0.7 & -0.7 & 0.9 \\
\hline P99.99-100 & 29.3 & 39.8 & 10.5 & 11.2 & -0.7 & -0.4 & -0.3 & -0.9 & 0.3 & -1.3 & 0.6 \\
\hline Top 20\% & 29.3 & 31.9 & 2.6 & 2.1 & 0.5 & -0.0 & 0.5 & -0.1 & 0.6 & -0.1 & 0.6 \\
\hline Top 10\% & 29.9 & 33.4 & 3.5 & 2.9 & 0.5 & -0.1 & 0.6 & -0.1 & 0.7 & -0.2 & 0.7 \\
\hline Top 5\% & 30.1 & 34.6 & 4.5 & 3.9 & 0.6 & -0.1 & 0.7 & -0.2 & 0.8 & -0.3 & 0.9 \\
\hline Top 1\% & 30.0 & 37.4 & 7.4 & 7.0 & 0.4 & -0.2 & 0.6 & -0.3 & 0.8 & -0.5 & 1.0 \\
\hline \multicolumn{12}{|c|}{ Post-tax income shares } \\
\hline P20-40 & 7.6 & 7.5 & -0.1 & 0.3 & -0.4 & 0.0 & -0.5 & 0.1 & -0.5 & 0.1 & -0.5 \\
\hline P40-60 & 13.9 & 13.7 & -0.1 & 0.2 & -0.4 & 0.0 & -0.4 & 0.0 & -0.4 & 0.0 & -0.4 \\
\hline P60-80 & 23.1 & 22.8 & -0.2 & 0.1 & -0.4 & 0.0 & -0.4 & 0.0 & -0.4 & 0.0 & -0.4 \\
\hline P80-90 & 17.1 & 17.5 & 0.4 & 0.1 & 0.2 & 0.0 & 0.2 & 0.0 & 0.2 & 0.0 & 0.2 \\
\hline P90-95 & 11.2 & 11.6 & 0.3 & 0.1 & 0.3 & 0.0 & 0.3 & 0.0 & 0.3 & 0.0 & 0.3 \\
\hline P95-99 & 13.3 & 13.8 & 0.5 & 0.0 & 0.5 & 0.0 & 0.5 & 0.0 & 0.5 & 0.0 & 0.5 \\
\hline P99-99.5 & 3.1 & 3.1 & 0.0 & -0.0 & 0.1 & -0.0 & 0.1 & -0.0 & 0.1 & -0.0 & 0.1 \\
\hline P99.5-99.9 & 4.5 & 4.2 & -0.3 & -0.3 & 0.0 & -0.1 & 0.1 & -0.2 & 0.2 & -0.2 & 0.3 \\
\hline P99.9-99.99 & 3.0 & 2.5 & -0.5 & -0.4 & -0.1 & -0.1 & -0.0 & -0.2 & 0.1 & -0.3 & 0.2 \\
\hline P99.99-100 & 1.9 & 1.5 & -0.4 & -0.3 & -0.1 & -0.1 & -0.0 & -0.1 & 0.0 & -0.2 & 0.1 \\
\hline Top 20\% & 54.1 & 54.1 & 0.0 & -0.8 & 0.9 & -0.0 & 0.9 & -0.1 & 1.0 & -0.1 & 1.0 \\
\hline Top 10\% & 37.0 & 36.7 & -0.3 & -0.9 & 0.6 & -0.3 & 0.9 & -0.4 & 1.0 & -0.5 & 1.1 \\
\hline Top 5\% & 25.8 & 25.1 & -0.6 & -1.0 & 0.4 & -0.4 & 0.7 & -0.6 & 0.9 & -0.7 & 1.0 \\
\hline Top 1\% & 12.5 & 11.4 & -1.1 & -1.0 & -0.1 & -0.3 & 0.2 & -0.5 & 0.4 & -0.8 & 0.7 \\
\hline
\end{tabular}

Note: PE: Policy effect. IPE: Indirect policy effect. OE: Other effect. RE: Residual effect. ETI: Elasticity of taxable income. Results for $\mathrm{ETI}=0$ correspond to the baseline results. If $\mathrm{ETI}=0$ : Total change $=\mathrm{PE}+\mathrm{OE}$. If ETI $>0: \mathrm{PE}$ is equal to (4). Total change $=\mathrm{PE}+$ $\mathrm{IPE}+\mathrm{RE}$. Average tax rates include federal and state level income and payroll taxes. Uprating according to the level of price inflation. Sources: Own calculations based on SOI IRS income tax return data and NBER TAXSIM calculator. 
(d) EGTRRA01/JGTRRA03

\begin{tabular}{|c|c|c|c|c|c|c|c|c|c|c|c|}
\hline \multirow{3}{*}{$\begin{array}{l}\text { data year: } \\
\text { policy year: }\end{array}$} & \multirow{3}{*}{$\begin{array}{l}2000 \\
2000 \\
(1)\end{array}$} & \multirow{3}{*}{$\begin{array}{l}2004 \\
2004 \\
(2) \\
\end{array}$} & \multirow{3}{*}{$\begin{array}{l}\text { Total } \\
\text { change } \\
(3)\end{array}$} & \multicolumn{2}{|c|}{$\mathrm{ETI}=0$} & \multicolumn{2}{|c|}{$\mathrm{ETI}=0.2$} & \multicolumn{2}{|c|}{$\mathrm{ETI}=0.5$} & \multicolumn{2}{|c|}{$\mathrm{ETI}=1.0$} \\
\hline & & & & $\mathrm{PE}$ & $\mathrm{OE}$ & IPE & $\mathrm{RE}$ & IPE & $\mathrm{RE}$ & IPE & $\mathrm{RE}$ \\
\hline & & & & (4) & $(5)$ & (6) & (7) & (8) & (9) & (10) & (11) \\
\hline \multicolumn{12}{|c|}{ Average tax rates } \\
\hline P20-40 & 10.5 & 2.3 & -8.2 & -2.0 & -6.2 & 0.2 & -6.4 & 0.4 & -6.6 & 0.7 & -7.0 \\
\hline $\mathrm{P} 40-60$ & 20.9 & 16.7 & -4.2 & -2.5 & -1.7 & 0.5 & -2.3 & 0.8 & -2.5 & 1.0 & -2.7 \\
\hline P60-80 & 25.9 & 23.2 & -2.7 & -2.1 & -0.7 & 0.4 & -1.0 & 0.4 & -1.1 & 0.5 & -1.1 \\
\hline P $80-90$ & 28.5 & 25.6 & -2.9 & -2.3 & -0.5 & 0.1 & -0.6 & 0.1 & -0.6 & 0.1 & -0.7 \\
\hline P90-95 & 30.6 & 27.7 & -2.9 & -2.5 & -0.4 & 0.0 & -0.5 & 0.1 & -0.5 & 0.1 & -0.5 \\
\hline P95-99 & 31.9 & 29.2 & -2.7 & -2.3 & -0.4 & 0.0 & -0.5 & 0.1 & -0.5 & 0.1 & -0.6 \\
\hline P99-99.5 & 33.9 & 31.8 & -2.1 & -2.3 & 0.2 & 0.0 & 0.1 & 0.0 & 0.1 & 0.1 & 0.1 \\
\hline P99.5-99.9 & 35.8 & 32.6 & -3.2 & -3.4 & 0.2 & 0.0 & 0.1 & 0.1 & 0.0 & 0.2 & -0.0 \\
\hline P99.9-99.99 & 36.6 & 32.9 & -3.7 & -4.3 & 0.6 & 0.1 & 0.5 & 0.1 & 0.5 & 0.2 & 0.4 \\
\hline P99.99-100 & 37.2 & 31.8 & -5.5 & -4.8 & -0.7 & 0.1 & -0.7 & 0.2 & -0.9 & 0.4 & -1.1 \\
\hline Top $20 \%$ & 32.1 & 28.9 & -3.2 & -2.7 & -0.5 & 0.0 & -0.5 & 0.0 & -0.5 & 0.1 & -0.6 \\
\hline Top $10 \%$ & 33.3 & 30.1 & -3.2 & -2.8 & -0.4 & 0.0 & -0.4 & 0.1 & -0.4 & 0.1 & -0.5 \\
\hline Top 5\% & 34.2 & 30.9 & -3.2 & -2.9 & -0.3 & 0.0 & -0.3 & 0.1 & -0.4 & 0.1 & -0.4 \\
\hline Top $1 \%$ & 35.9 & 32.3 & -3.5 & -3.6 & 0.1 & 0.0 & 0.0 & 0.1 & & 0.2 & -0.1 \\
\hline \multicolumn{12}{|c|}{ Post-tax income shares } \\
\hline P20-40 & 7.3 & 7.1 & -0.2 & -0.1 & -0.1 & -0.0 & -0.1 & -0.0 & -0.0 & -0.0 & -0.0 \\
\hline $\mathrm{P} 40-60$ & 12.4 & 12.4 & -0.0 & -0.1 & 0.0 & -0.1 & 0.1 & -0.0 & 0.1 & -0.1 & 0.1 \\
\hline P60-80 & 20.5 & 20.9 & 0.3 & -0.1 & 0.5 & -0.1 & 0.5 & -0.1 & 0.6 & -0.2 & 0.6 \\
\hline P80-90 & 15.8 & 16.4 & 0.6 & -0.0 & 0.6 & -0.0 & 0.6 & -0.0 & 0.6 & -0.0 & 0.6 \\
\hline P90-95 & 10.9 & 11.2 & 0.4 & 0.0 & 0.3 & 0.0 & 0.3 & 0.0 & 0.3 & 0.0 & 0.3 \\
\hline P95-99 & 14.2 & 14.2 & 0.0 & 0.0 & 0.0 & 0.0 & -0.0 & 0.0 & -0.0 & 0.0 & -0.0 \\
\hline P99-99.5 & 3.6 & 3.4 & -0.2 & 0.0 & -0.2 & 0.0 & -0.2 & 0.0 & -0.2 & 0.0 & -0.2 \\
\hline P99.5-99.9 & 5.6 & 5.2 & -0.3 & 0.1 & -0.4 & 0.0 & -0.4 & 0.0 & -0.5 & 0.0 & -0.5 \\
\hline P99.9-99.99 & 4.5 & 3.9 & -0.5 & 0.1 & -0.6 & 0.0 & -0.7 & 0.1 & -0.7 & 0.1 & -0.7 \\
\hline P99.99-100 & 2.8 & 2.8 & -0.0 & 0.1 & -0.1 & 0.0 & -0.2 & 0.1 & -0.2 & 0.1 & -0.3 \\
\hline Top $20 \%$ & 57.4 & 57.2 & -0.2 & 0.3 & -0.4 & 0.0 & -0.5 & 0.1 & -0.5 & 0.1 & -0.5 \\
\hline Top $10 \%$ & 41.5 & 40.8 & -0.7 & 0.3 & -1.0 & 0.1 & -1.1 & 0.2 & -1.2 & 0.2 & -1.2 \\
\hline Top 5\% & 30.7 & 29.6 & -1.1 & 0.3 & -1.4 & 0.1 & -1.5 & 0.2 & -1.6 & 0.3 & -1.6 \\
\hline Top $1 \%$ & 16.5 & 15.4 & -1.1 & 0.3 & -1.4 & 0.1 & -1.5 & 0.2 & -1.6 & 0.3 & -1.7 \\
\hline
\end{tabular}

Note: PE: Policy effect. IPE: Indirect policy effect. OE: Other effect. RE: Residual effect. ETI: Elasticity of taxable income. Results for $\mathrm{ETI}=0$ correspond to the baseline results. If $\mathrm{ETI}=0$ : Total change $=\mathrm{PE}+\mathrm{OE}$. If ETI $>0: \mathrm{PE}$ is equal to (4). Total change $=\mathrm{PE}+$ $\mathrm{IPE}+\mathrm{RE}$. Average tax rates include federal and state level income and payroll taxes. Uprating according to the level of price inflation. Sources: Own calculations based on SOI IRS income tax return data and NBER TAXSIM calculator. 
Table 5: Robustness check: Ranking of taxunits, TRA86

\begin{tabular}{|c|c|c|c|c|c|c|c|c|c|c|c|}
\hline \multirow{5}{*}{$\begin{array}{l}\text { data year: } \\
\text { adjusted to: } \\
\text { policy year }\end{array}$} & \multirow{3}{*}{$\begin{array}{r}1986 \\
1986\end{array}$} & \multirow{2}{*}{$\begin{array}{l}1988 \\
1986\end{array}$} & \multirow{2}{*}{$\begin{array}{l}1986 \\
1988\end{array}$} & \multirow[t]{2}{*}{1988} & \multirow[b]{2}{*}{ Total } & \multicolumn{2}{|c|}{ Decomp. I } & \multicolumn{2}{|c|}{ Decomp. II } & \multicolumn{2}{|c|}{ Shapley-Dec. } \\
\hline & & & & & & $\mathrm{PE}$ & $\mathrm{OE}$ & $\mathrm{PE}$ & $\mathrm{OE}$ & $\mathrm{PE}$ & $\mathrm{OE}$ \\
\hline & & 1986 & 1988 & 1988 & change & & & & & Mean & Mean \\
\hline & & & & & & & & & & $(4)-(2)$ & $(2)-(1)$ \\
\hline & (1) & $(2)$ & $(3)$ & $(4)$ & $(4)-(1)$ & $(4)-(2)$ & $(2)-(1)$ & $(3)-(1)$ & $(4)-(3)$ & $(3)-(1)$ & $(4)-(3)$ \\
\hline \multicolumn{12}{|c|}{ Average tax rates } \\
\hline P $20-40$ & 14.5 & 15.0 & 13.6 & 14.1 & -0.4 & -0.8 & 0.5 & -0.9 & 0.5 & -0.9 & 0.5 \\
\hline P40-60 & 21.4 & 22.1 & 21.1 & 21.2 & -0.1 & -0.9 & 0.7 & -0.3 & 0.1 & -0.6 & 0.4 \\
\hline P60-80 & 25.6 & 26.7 & 25.6 & 25.6 & -0.0 & -1.1 & 1.0 & -0.1 & 0.0 & -0.6 & 0.5 \\
\hline P $80-90$ & 28.2 & 30.6 & 27.7 & 27.8 & -0.3 & -2.8 & 2.5 & -0.5 & 0.1 & -1.6 & 1.3 \\
\hline P90-95 & 29.2 & 33.8 & 29.2 & 29.2 & 0.1 & -4.6 & 4.7 & 0.0 & 0.0 & -2.3 & 2.3 \\
\hline P95-99 & 30.6 & 35.6 & 30.7 & 29.9 & -0.7 & -5.7 & 5.0 & 0.1 & -0.8 & -2.8 & 2.1 \\
\hline P99-99.5 & 33.1 & 36.4 & 33.8 & 30.5 & -2.6 & -5.9 & 3.3 & 0.7 & -3.3 & -2.6 & -0.0 \\
\hline P99.5-99.9 & 38.0 & 39.3 & 36.1 & 30.5 & -7.5 & -8.8 & 1.3 & -1.9 & -5.6 & -5.4 & -2.1 \\
\hline P99.9-99.99 & 45.5 & 41.5 & 44.4 & 30.0 & -15.5 & -11.5 & -4.0 & -1.1 & -14.4 & -6.3 & -9.2 \\
\hline P99.99-100 & 48.6 & 37.9 & 52.3 & 29.3 & -19.3 & -8.5 & -10.7 & 3.7 & -23.0 & -2.4 & -16.9 \\
\hline Top $20 \%$ & 31.5 & 34.7 & 31.3 & 29.2 & -2.3 & -5.5 & 3.2 & -0.2 & -2.1 & -2.8 & 0.5 \\
\hline Top $10 \%$ & 33.1 & 36.4 & 33.1 & 29.8 & -3.3 & -6.6 & 3.3 & -0.0 & -3.3 & -3.3 & 0.0 \\
\hline Top 5\% & 35.0 & 37.4 & 34.9 & 30.1 & -4.9 & -7.4 & 2.4 & -0.0 & -4.9 & -3.7 & -1.2 \\
\hline Top 1\% & 40.2 & 39.0 & 40.0 & 30.2 & -10.0 & -8.8 & -1.2 & -0.2 & -9.9 & -4.5 & -5.5 \\
\hline \multicolumn{12}{|c|}{ Post-tax income shares } \\
\hline P20-40 & 7.7 & 7.7 & 7.8 & 7.4 & -0.3 & -0.3 & -0.0 & 0.0 & -0.4 & -0.1 & -0.2 \\
\hline P40-60 & 14.7 & 14.3 & 14.7 & 13.8 & -0.9 & -0.5 & -0.4 & 0.0 & -0.9 & -0.2 & -0.6 \\
\hline P60-80 & 24.5 & 23.6 & 24.5 & 22.9 & -1.6 & -0.7 & -0.9 & -0.0 & -1.6 & -0.4 & -1.3 \\
\hline P80-90 & 18.0 & 17.1 & 18.1 & 16.9 & -1.0 & -0.1 & -0.9 & 0.1 & -1.1 & -0.0 & -1.0 \\
\hline P90-95 & 11.6 & 10.9 & 11.6 & 11.1 & -0.6 & 0.2 & -0.8 & -0.0 & -0.5 & 0.1 & -0.6 \\
\hline P95-99 & 13.1 & 12.7 & 13.0 & 13.1 & -0.0 & 0.4 & -0.5 & -0.1 & 0.1 & 0.2 & -0.2 \\
\hline P99-99.5 & 2.7 & 3.0 & 2.6 & 3.1 & 0.4 & 0.1 & 0.3 & -0.0 & 0.4 & 0.0 & 0.4 \\
\hline P99.5-99.9 & 3.3 & 4.4 & 3.4 & 4.7 & 1.4 & 0.4 & 1.1 & 0.1 & 1.3 & 0.2 & 1.2 \\
\hline P99.9-99.99 & 2.0 & 3.1 & 2.0 & 3.5 & 1.6 & 0.4 & 1.2 & 0.0 & 1.5 & 0.2 & 1.3 \\
\hline P99.99-100 & 1.2 & 2.4 & 1.1 & 2.6 & 1.4 & 0.2 & 1.2 & -0.1 & 1.5 & 0.0 & 1.3 \\
\hline Top $20 \%$ & 51.9 & 53.5 & 51.9 & 55.0 & 3.1 & 1.6 & 1.6 & -0.0 & 3.1 & 0.8 & 2.4 \\
\hline Top $10 \%$ & 33.9 & 36.4 & 33.8 & 38.1 & 4.2 & 1.7 & 2.5 & -0.1 & 4.3 & 0.8 & 3.4 \\
\hline Top 5\% & 22.3 & 25.5 & 22.2 & 27.0 & 4.7 & 1.5 & 3.2 & -0.1 & 4.8 & 0.7 & 4.0 \\
\hline Top 1\% & 9.1 & 12.8 & 9.1 & 13.9 & 4.8 & 1.1 & 3.7 & 0.0 & 4.8 & 0.5 & 4.2 \\
\hline
\end{tabular}

Note: PE: Policy effect. OE: Other effect. Average tax rates (\%) include federal and state level income and payroll taxes. Uprating according to the level of price inflation. Ranking based on pre-tax income incl. capital gains. Sources: Own calculations based on SOI IRS income tax return data and NBER TAXSIM calculator. 
Figure 7: Income shares: Direct vs. total policy effect with low ETI

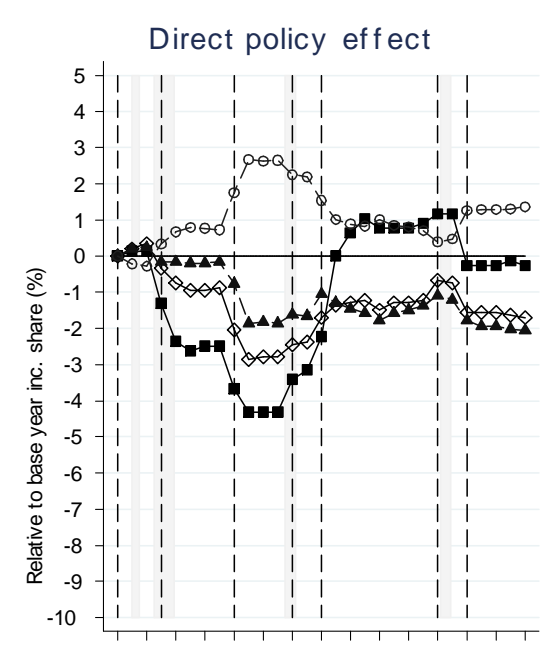

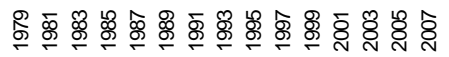

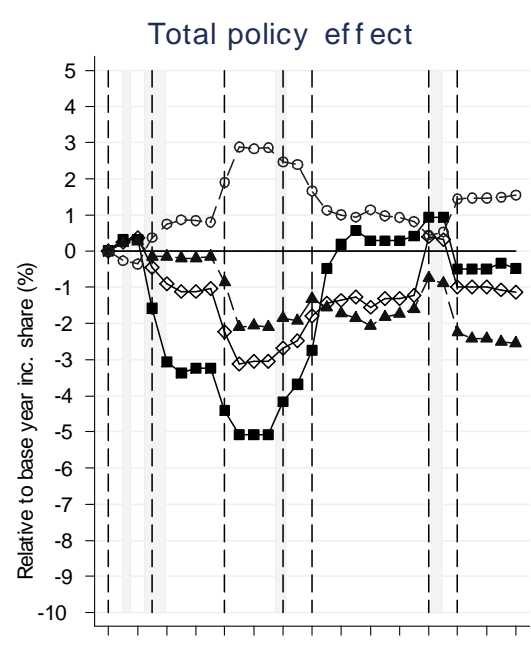

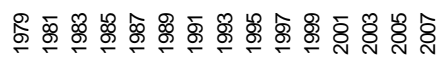

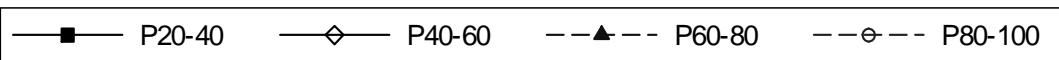

Note: P20-40: Second quintile, P40-60: Third quintile, P60-80: Fourth quintile. P80-100: The dashed vertical lines indicate the start of implementation of significant changes in tax legislation (section 3.4). Shaded areas show recession periods (NBER classification). ETI = 0.2. Uprating according to the level of price inflation. Sources: Own calculations based on SOI IRS income tax return data and NBER TAXSIM calculator. 
Figure 8: Income shares: Direct vs. total policy effect with medium ETI

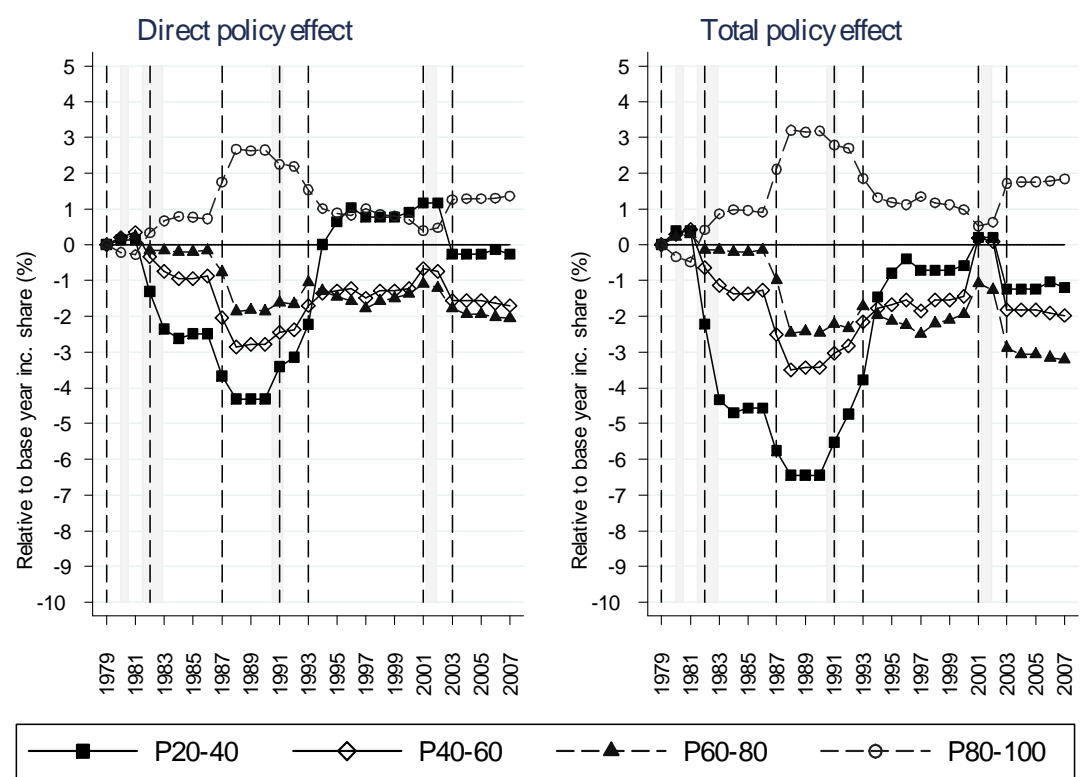

Note: P20-40: Second quintile, P40-60: Third quintile, P60-80: Fourth quintile. P80-100: The dashed vertical lines indicate the start of implementation of significant changes in tax legislation (section 3.4). Shaded areas show recession periods (NBER classification). ETI $=0.5$. Uprating according to the level of price inflation. Sources: Own calculations based on SOI IRS income tax return data and NBER TAXSIM calculator. 
Figure 9: Income shares with uprating according to mean nominal wage growth

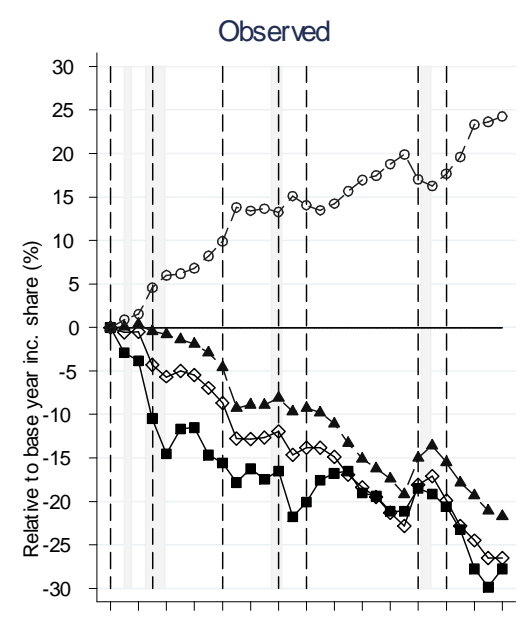

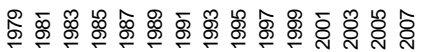

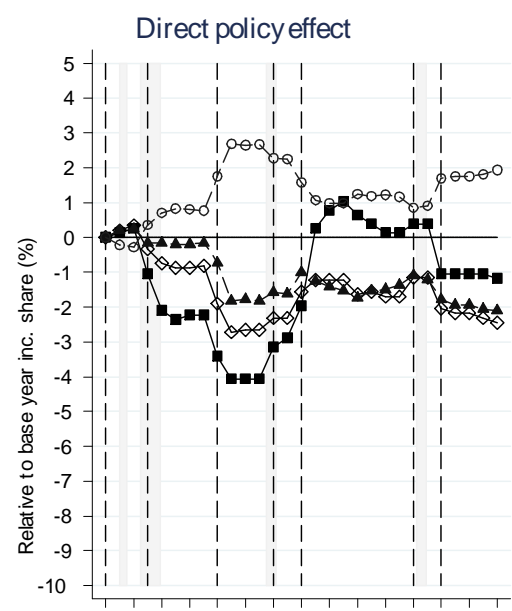

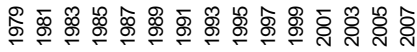

$\longrightarrow \mathrm{P} 20-40 \longrightarrow \mathrm{P} 40-60 \quad--\Delta--\mathrm{P} 60-80 \quad--\theta--\mathrm{P} 80-100$

Note: P20-40: Second quintile, P40-60: Third quintile, P60-80: Fourth quintile. P80-100: The dashed vertical lines indicate the start of implementation of significant changes in tax legislation (section 3.4). Shaded areas show recession periods (NBER classification). Uprating according to mean nominal wage growth. Sources: Own calculations based on SOI IRS income tax return data and NBER TAXSIM calculator.

Figure 10: Comparison of policy effect on Gini SOI - CPS

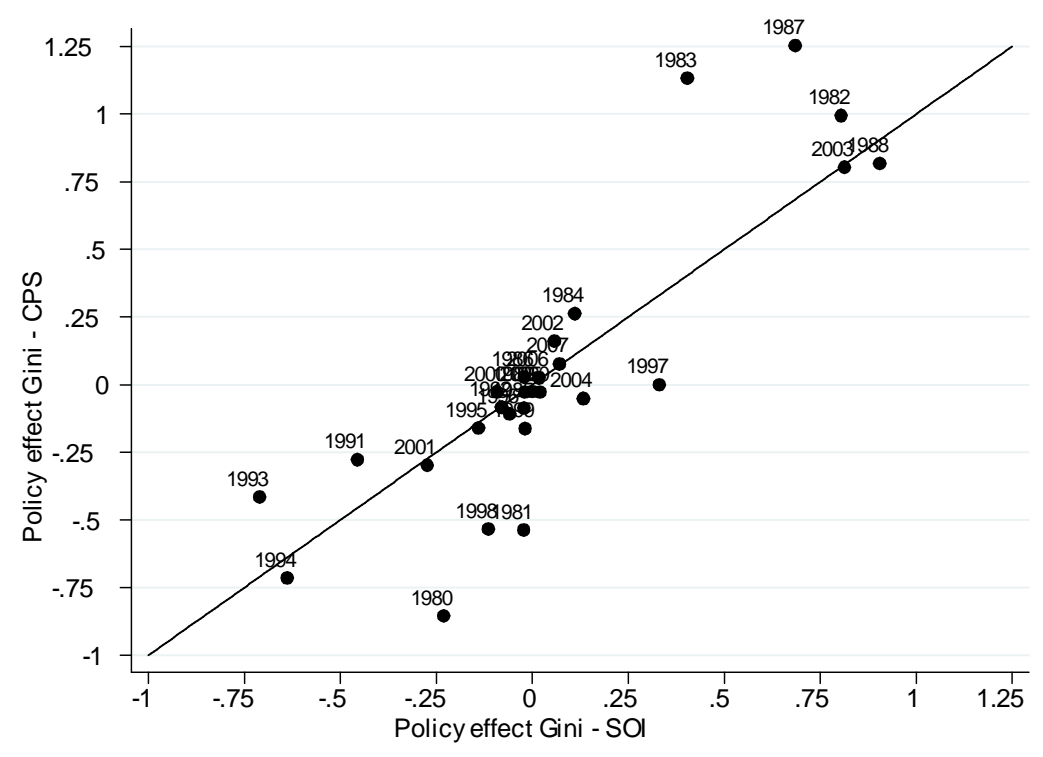

Sources: Own calculations based on SOI IRS income tax return data, CPS data and NBER TAXSIM calculator. 


\section{Data sources: Partisan regressions}

State political variables. State political variables are from Klarner (2003), as well as updates available on the State Politics and Policy Web Site.

(http://academic.udayton.edu/SPPQ-TPR/klarner_datapage.html, accessed at January 15th, 2013). ADA Average is from Anderson and Habel (2009).

State economic variables. The series on direct policy effects as well as post-tax inequality measures result from own calculations based on SOI IRS income tax return data and NBER TAXSIM calculator. Data on state per capita personal income, farm and manufacturing share is provided by the Bureau of Economic Analysis.

Other state characteristics variables. State characteristics such as percent elderly, percent black, percent female and percent college-educated are based on information contained in IPUMS CPS. Data on union density is from Hirsch et al. (2001), with updates available on http://unionstats.gsu.edu/MonthlyLaborReviewArticle.htm (accessed at January 15th, 2013). Population density is provided by the Census Bureau. 
Table 6: Descriptive Statistics: Partisan regressions

\begin{tabular}{lcccccc}
\hline \hline Post-tax inequality & Mean & StdDev & Mean change & StdDev & Mean PE & StdDev \\
\hline P0-20 & 3.456 & 0.606 & -0.023 & 0.626 & -0.003 & 0.053 \\
P20-40 & 8.710 & 1.064 & -0.062 & 0.819 & -0.001 & 0.062 \\
P40-60 & 14.555 & 1.680 & -0.096 & 1.203 & -0.007 & 0.058 \\
P60-80 & 23.107 & 2.395 & -0.118 & 1.727 & -0.015 & 0.075 \\
P80-100 & 50.172 & 4.990 & 0.299 & 3.435 & 0.026 & 0.188 \\
Top 10\% & 34.442 & 6.444 & 0.318 & 4.610 & 0.022 & 0.204 \\
Top 5\% & 23.462 & 6.793 & 0.296 & 4.916 & 0.015 & 0.219 \\
Top 1\% & 10.656 & 5.520 & 0.244 & 3.964 & 0.010 & 0.185 \\
Gini & 48.683 & 5.141 & 0.301 & 3.655 & 0.016 & 0.196 \\
\hline Pol. party variables & Mean & StdDev & Min & Max & & \\
\hline Democratic Legislature & 50.24 & 50.02 & 0 & 100 & & \\
Republican Legislature & 27.92 & 44.87 & 0 & 100 & & \\
Republican Governor & 46.41 & 49.89 & 0 & 100 & & \\
Dem. Gov. and Leg. & 28.83 & 45.31 & 0 & 100 & & \\
Rep. Gov. and Leg. & 16.79 & 37.39 & 0 & 100 & & \\
Republican President & 55.59 & 49.70 & 0 & 100 & & \\
Rep. Pres. and Congress & 16.68 & 37.29 & 0 & 100 & & \\
\hline State charact. variables & Mean & StdDev & Min & Max & & \\
\hline Log of Real PCPI & 3.19 & 0.20 & 2.69 & 3.82 & & \\
ADA Average & 41.92 & 21.70 & -5.02 & 90.85 & & \\
Percent Elderaly & 11.93 & 1.91 & 5.85 & 18.39 & & \\
Percent Black & 10.39 & 9.76 & 0 & 41.23 & & \\
Percent Female & 51.14 & 1.01 & 47.73 & 54.33 & & \\
Percent College-Educated & 12.09 & 6.80 & 1.57 & 31.35 & & \\
Percent Union & 14.58 & 6.90 & 2.30 & 38.30 & & \\
Population Density & 177.07 & 240.12 & 4.55 & 1176.33 & & \\
Farm share & 1.24 & 1.68 & 0 & 16.38 & & \\
Manufacturing share & 13.36 & 6.29 & 2.62 & 35.70 & & \\
Unemployment rate & 6.06 & 2.08 & 2.30 & 17.40 & & \\
\hline \hline & & & & & & \\
\hline
\end{tabular}

Note: StdDev: Standard deviation. PE: Policy effect. PCPI: Per Capita Personal Income. ADA: Average: average Americans for Democratic Action score. Sources: See overview in Appendix A.2. 
Table 7: Partisan effect on inequality

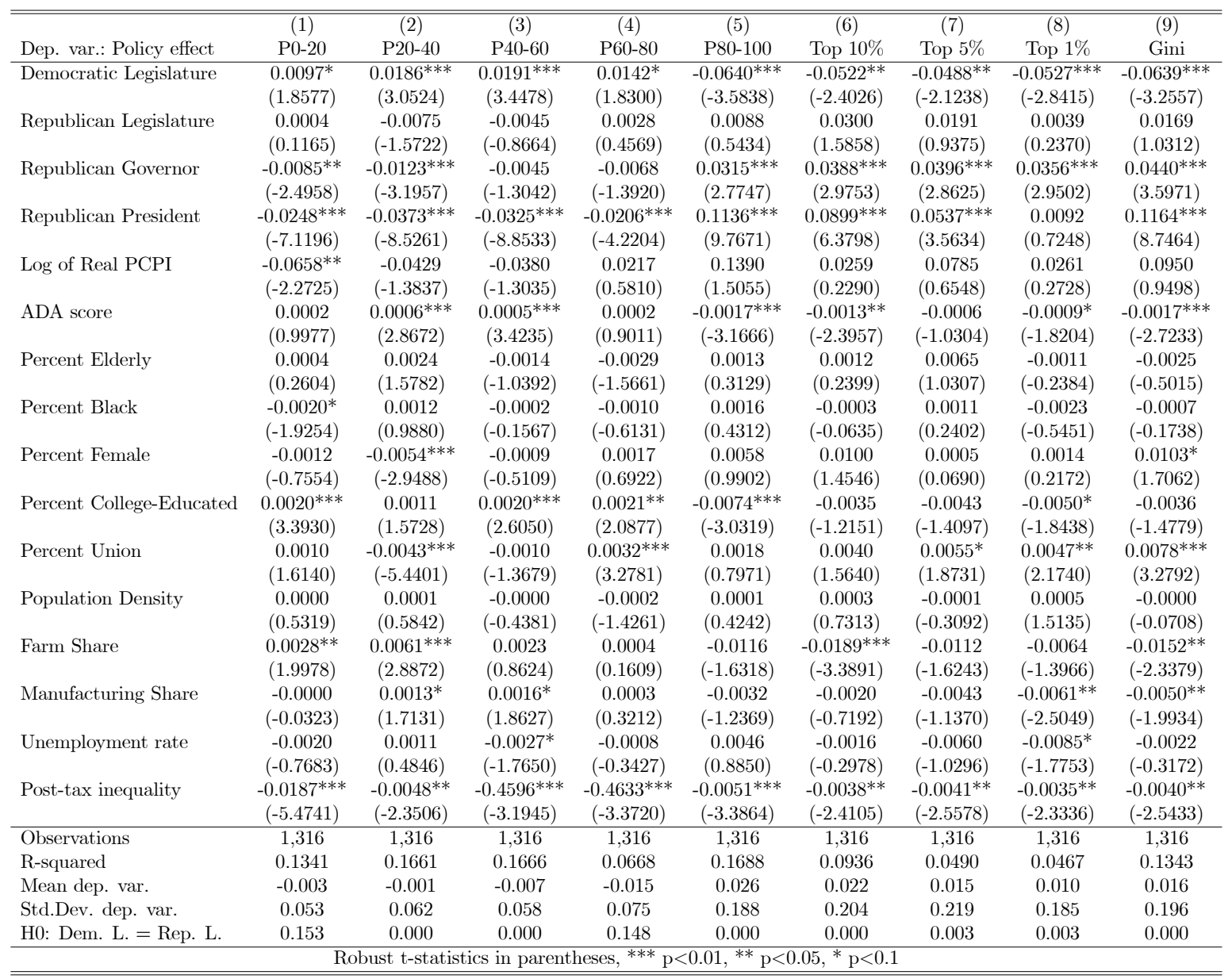

Note: In columns (1)-(8), dependent variable is the state-level policy effect on the income share of various income groups. In column (9), dependent variable is the state-level Gini coefficient. All specifications include state fixed effects. We estimate robust standard errors. The last row shows p-values for the hypothesis test $\beta_{\text {Dem.Legislature }}=\beta_{\text {Re } p \text {.Legislature }}$. PCPI: Per Capita Personal Income. ADA: average Americans for Democratic Action score. Sources: See overview in Appendix A.2. 
Table 8: Partisan regressions with time fixed effects for federal legislative terms

\begin{tabular}{|c|c|c|c|c|c|c|c|c|c|}
\hline & (1) & 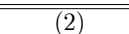 & $\begin{array}{l}(3) \\
\end{array}$ & (4) & $\overline{c(5)}$ & $\begin{array}{l}(6) \\
\end{array}$ & $\begin{array}{c}(7) \\
\end{array}$ & (8) & $\begin{array}{c}(9) \\
\end{array}$ \\
\hline Dep. var.: Policy effect & $\mathrm{P} 0-20$ & P20-40 & P40-60 & P60-80 & P80-100 & Top $10 \%$ & Top $5 \%$ & Top $1 \%$ & Gini \\
\hline Democratic Legislature & $\begin{array}{c}0.0083^{*} \\
(1.6668)\end{array}$ & $\begin{array}{c}0.0149^{* *} \\
(2.5687)\end{array}$ & $\begin{array}{c}0.0164^{* * *} \\
(3.1795)\end{array}$ & $\begin{array}{c}0.0117 \\
(1.5640)\end{array}$ & $\begin{array}{c}-0.0516^{* * *} \\
(-3.2478)\end{array}$ & $\begin{array}{c}-0.0436^{* *} \\
(-2.1184)\end{array}$ & $\begin{array}{l}-0.0430^{*} \\
(-1.9612)\end{array}$ & $\begin{array}{c}-0.0502^{* * *} \\
(-2.8346)\end{array}$ & $\begin{array}{c}-0.0514^{* * *} \\
(-2.8430)\end{array}$ \\
\hline Republican Legislature & $\begin{array}{c}0.0017 \\
(0.4962)\end{array}$ & $\begin{array}{c}0.0022 \\
(0.4992)\end{array}$ & $\begin{array}{c}0.0007 \\
(0.1315)\end{array}$ & $\begin{array}{c}0.0033 \\
(0.5426)\end{array}$ & $\begin{array}{c}-0.0088 \\
(-0.5905)\end{array}$ & $\begin{array}{c}0.0083 \\
(0.4643)\end{array}$ & $\begin{array}{c}-0.0023 \\
(-0.1157)\end{array}$ & $\begin{array}{l}-0.0183 \\
(-1.2009)\end{array}$ & $\begin{array}{c}-0.0094 \\
(-0.6266)\end{array}$ \\
\hline Republican Governor & $\begin{array}{r}-0.0066^{* *} \\
(-2.0375)\end{array}$ & $\begin{array}{c}-0.0095^{* * *} \\
(-2.6559)\end{array}$ & $\begin{array}{c}-0.0037 \\
(-1.1431)\end{array}$ & $\begin{array}{l}-0.0088^{*} \\
(-1.9130)\end{array}$ & $\begin{array}{c}0.0278^{* * *} \\
(2.7442)\end{array}$ & $\begin{array}{c}0.0359 * * * \\
(2.9362)\end{array}$ & $\begin{array}{c}0.0372 * * * \\
(2.8624)\end{array}$ & $\begin{array}{c}0.0339 * * * \\
(2.9385)\end{array}$ & $\begin{array}{c}0.0363 * * * \\
(3.2336)\end{array}$ \\
\hline Observations & 1,316 & 1,316 & 1,316 & 1,316 & 1,316 & 1,316 & 1,316 & 1,316 & 1,316 \\
\hline R-squared & 0.2105 & 0.3127 & 0.2711 & 0.2029 & 0.3407 & 0.2289 & 0.1670 & 0.1750 & 0.2956 \\
\hline Mean dep. var. & -0.003 & -0.001 & -0.007 & -0.015 & 0.026 & 0.022 & 0.015 & 0.010 & 0.016 \\
\hline Std.Dev. dep. var. & 0.053 & 0.062 & 0.058 & 0.075 & 0.188 & 0.204 & 0.219 & 0.185 & 0.196 \\
\hline H0: Dem. L. = Rep. L. & 0.328 & 0.075 & 0.006 & 0.283 & 0.017 & 0.015 & 0.062 & 0.080 & 0.044 \\
\hline
\end{tabular}

Note: In columns (1)-(8), dependent variable is the state-level policy effect on the income share of various income groups. In column (9), dependent variable is the state-level Gini coefficient. All specifications include state fixed effects and federal legislative term dummies. We estimate robust standard errors. The last row shows p-values for the

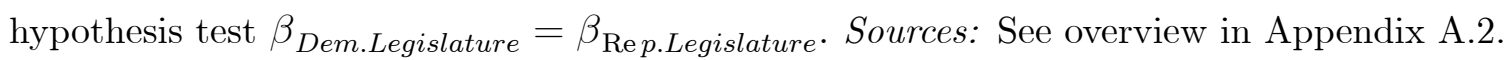




\section{A.3 Online Appendix}

Table 9: Tax Legislation

\begin{tabular}{|c|c|c|c|c|c|c|}
\hline & 1978 & 1979 & 1980 & 1981 & 1982 & 1983 \\
\hline \multicolumn{7}{|l|}{ Income Tax } \\
\hline Number of tax brackets* & 26 & 16 & 16 & 16 & 13 & 14 \\
\hline Lowest individual income tax rate** & $14^{\% * * *}$ & $14 \% * * *$ & $14^{* * * *}$ & $13.83 \%$ \%** & $12^{\%} \%^{* * *}$ & $11 \%$ *** \\
\hline $\begin{array}{l}\text { Lowest individual income single tax } \\
\text { bracket }\end{array}$ & $\$ 2,200-\$ 2,700$ & $\$ 2,300-\$ 3,400$ & $\$ 2,300-\$ 3,400$ & $\$ 2,300-\$ 3,400$ & $\$ 2,300-\$ 3,400$ & $\$ 2,300-\$ 3,400$ \\
\hline $\begin{array}{l}\text { Lowest individual income joint tax } \\
\text { bracket }\end{array}$ & $\$ 3,200-\$ 4200$ & $\$ 3,400-\$ 5500$ & $\$ 3,400-\$ 5,500$ & $\$ 3,400-\$ 5,500$ & $\$ 3,400-\$ 5,500$ & $\$ 3,400-\$ 5,500$ \\
\hline $\begin{array}{l}\text { Other individual income tax brackets } \\
\text { (percent)*, } * * * *\end{array}$ & $\begin{array}{c}15,16,17,19,22,25, \\
28,32,36,39,42,45, \\
48,50,53,55,58,60, \\
62,64,66,68,69,\end{array}$ & $\begin{array}{c}16,18,21,24,28, \\
3237,43,49,54, \\
59,64,68\end{array}$ & $\begin{array}{c}16,18,21,24,28,32 \\
37,43,49,54,59,64 \\
68\end{array}$ & $\begin{array}{c}16,18,21,24,28, \\
3237,43,49,54, \\
59,64,68\end{array}$ & $\begin{array}{l}14,16,19,22,25 \\
29,33,39,44,49\end{array}$ & $\begin{array}{c}13,15,17,19,23 \\
26,30,35,40,44, \\
48\end{array}$ \\
\hline $\begin{array}{l}\text { Highest individual income tax bracket } \\
\text { rate }\end{array}$ & $70 \%$ & $70 \%$ & $70 \%$ & $70 \%$ & $50 \%$ & $50 \%$ \\
\hline Rate on long-term capital gains & $\begin{array}{l}40 \% \text { of individual rate, } \\
\text { maximum } 39.875 \%\end{array}$ & $\begin{array}{l}40 \% \text { of individual } \\
\text { rate, maximum } 28 \%\end{array}$ & $\begin{array}{l}40 \% \text { of individual } \\
\text { rate, maximum } 28 \%\end{array}$ & $\begin{array}{l}40 \% \text { of individual } \\
\text { rate, maximum } 20 \%\end{array}$ & $\begin{array}{l}40 \% \text { of individual } \\
\text { rate, maximum } 20 \%\end{array}$ & $\begin{array}{l}40 \% \text { of individual } \\
\text { rate, maximum } 20 \%\end{array}$ \\
\hline Rate on dividends & $=$ individual rates & $=$ individual rates & $=$ individual rates & $=$ individual rates & $=$ individual rates & $=$ individual rates \\
\hline $\begin{array}{l}\text { Limitations on personal exemption and } \\
\text { itemized deductions }\end{array}$ & N.A. & N.A. & N.A. & N.A. & N.A. & N.A. \\
\hline Standard Deduction & $\begin{array}{c}\$ 2,200 \text { (single person) } \\
/ \$ 3,200 \text { (married } \\
\text { couple) }\end{array}$ & $\begin{array}{c}\$ 2,300 \text { (single } \\
\text { person) / } \$ 3,400 \\
\text { (married couple) }\end{array}$ & $\begin{array}{c}\$ 2,300 \text { (single person) } \\
/ \$ 3,400 \text { (married } \\
\text { couple) }\end{array}$ & $\begin{array}{c}\$ 2,300 \text { (single } \\
\text { person) / } \$ 3,400 \\
\text { (married couple) }\end{array}$ & $\begin{array}{c}\$ 2,300 \text { (single } \\
\text { person) } / \$ 3,400 \\
\text { (married couple) }\end{array}$ & $\begin{array}{c}\$ 2,300 \text { (single } \\
\text { person) / } \$ 3,400 \\
\text { (married couple) }\end{array}$ \\
\hline AMT exemption***** & $\begin{array}{l}\$ 20,000 \text { for joint and } \\
\text { single filers }\end{array}$ & $\begin{array}{l}\$ 20,000 \text { for joint } \\
\text { and single filers }\end{array}$ & $\begin{array}{l}\$ 20,000 \text { for joint and } \\
\text { single filers }\end{array}$ & $\begin{array}{l}\$ 20,000 \text { for joint } \\
\text { and single filers }\end{array}$ & $\begin{array}{l}\$ 30,000 \text { for single } \\
\text { filers, } \$ 40,000 \text { for } \\
\text { joint filers }\end{array}$ & $\begin{array}{c}\$ 30,000 \text { for single } \\
\text { filers, } \$ 40,000 \text { for } \\
\text { joint filers }\end{array}$ \\
\hline
\end{tabular}




\begin{tabular}{|c|c|c|c|c|c|c|}
\hline & 1978 & 1979 & 1980 & 1981 & 1982 & 1983 \\
\hline \multicolumn{7}{|l|}{ Taxcredits } \\
\hline Child tax credit & N.A. & N.A. & N.A. & N.A. & N.A. & N.A. \\
\hline $\begin{array}{l}\text { Child and dependent care tax credit } \\
\text { (non-refundable)***** }\end{array}$ & $\begin{array}{l}\$ 400 \text { for each of first } 2 \\
\text { dependents, maximum } \\
20 \% \text { of expenditures }\end{array}$ & $\begin{array}{l}\$ 400 \text { for each of } \\
\text { first } 2 \text { dependents, } \\
\text { maximum } 20 \% \text { of } \\
\text { expenditures }\end{array}$ & $\begin{array}{l}\$ 400 \text { for each of first } \\
2 \text { dependents, } \\
\text { maximum } 20 \% \text { of } \\
\text { expenditures }\end{array}$ & $\begin{array}{l}\text { Maximum } \\
\text { expenditure eligible } \\
\text { for credit is } \$ 2,400 \\
\text { for one child, } \\
\$ 4,800 \text { for two or } \\
\text { more; maximimum } \\
\text { credit is } 20 \%-30 \% \\
\text { of expenditures }\end{array}$ & $\begin{array}{l}\text { Maximum } \\
\text { expenditure eligible } \\
\text { for credit is } \$ 2,400 \\
\text { for one child, } \\
\$ 4,800 \text { for two or } \\
\text { more; maximimum } \\
\text { credit is } 20 \%-30 \% \\
\text { of expenditures }\end{array}$ & $\begin{array}{l}\text { Maximum } \\
\text { expenditure eligible } \\
\text { for credit is } \$ 2,400 \\
\text { for one child, } \\
\$ 4,800 \text { for two or } \\
\text { more; maximimum } \\
\text { credit is } 20 \%-30 \% \\
\text { of expenditures }\end{array}$ \\
\hline EITC rate and maximum credit & $10 \%, \max . \$ 400$ & $10 \%, \max . \$ 500$ & $10 \%$, max. $\$ 500$ & $10 \%, \max . \$ 500$ & $10 \%$, max. $\$ 500$ & $10 \%, \max . \$ 500$ \\
\hline EITC phaseout range and rate & $\begin{array}{l}\$ 6,000-\$ 10,000 \\
12.5 \%\end{array}$ & $\begin{array}{l}\$ 6,000-\$ 10,000 \\
12.5 \%\end{array}$ & $\begin{array}{l}\$ 6,000-\$ 10,000 \\
12.5 \%\end{array}$ & $\begin{array}{l}\$ 6,000-\$ 10,000 \\
12.5 \%\end{array}$ & $\begin{array}{l}\$ 6,000-\$ 10,000 \\
12.5 \%\end{array}$ & $\begin{array}{l}\$ 6,000-\$ 10,000 \\
12.5 \%\end{array}$ \\
\hline \multicolumn{7}{|l|}{ Social Sec urity $[a]$} \\
\hline Social Security tax rate (OASDI) [b] & $10.1 \%$ & $10.16 \%$ & $10.16 \%$ & $10.7 \%$ & $10.8 \%$ & $10.8 \%$ \\
\hline Hospital Insurance tax rate $(\mathrm{HI})[\mathrm{c}]$ & $2.0 \%$ & $2.1 \%$ & $2.1 \%$ & $2.6 \%$ & $2.6 \%$ & $2.6 \%$ \\
\hline OASDI taxable maximum earnings & 17,700 & 22,900 & 25,900 & 29,700 & 32,400 & 35,700 \\
\hline HI taxable maximum earnings [d] & 17,700 & 22,900 & 25,900 & 29,700 & 32,400 & 35,700 \\
\hline
\end{tabular}

\begin{tabular}{|c|c|c|c|c|c|c|}
\hline & 1984 & 1985 & 1986 & 1987 & 1988 & 1989 \\
\hline \multicolumn{7}{|l|}{ Income Tax } \\
\hline Number of tax brackets* & 15 & 15 & 15 & 5 & 4 & 4 \\
\hline Lowest individual income tax rate** & $11 \%$ *** & $11 \%^{* * *}$ & $11 \%^{* * *}$ & $11 \%$ & $15 \%$ & $15 \%$ \\
\hline $\begin{array}{l}\text { Lowest individual income single tax } \\
\text { bracket }\end{array}$ & $\$ 2,300-\$ 3,400$ & $\$ 2,390-\$ 3,540$ & $\$ 2,480-\$ 3,670$ & $\$ 0-\$ 1,800$ & $\$ 0-\$ 17,850$ & $\$ 0-\$ 18,550$ \\
\hline $\begin{array}{l}\text { Lowest individual income joint tax } \\
\text { bracket }\end{array}$ & $\$ 3,400-\$ 5,500$ & $\$ 3,540-\$ 5,720$ & $\$ 3,670-\$ 5,940$ & $\$ 0-\$ 3,000$ & $\$ 0-\$ 29,750$ & $\$ 0-\$ 30,950$ \\
\hline $\begin{array}{l}\text { Other individual income tax brackets } \\
\text { (percent)*,**** }\end{array}$ & $\begin{array}{c}12,14,16,18,22 \\
25,28,33,38,42 \\
45,49\end{array}$ & $\begin{array}{c}12,14,16,18,22 \\
25,28,33,38,42 \\
45,49\end{array}$ & $\begin{array}{c}12,14,16,18,22 \\
25,28,33,38,42 \\
45,49\end{array}$ & $15,28,35$ & 28,33 & 28,33 \\
\hline $\begin{array}{l}\text { Highest individual income tax bracket } \\
\text { rate }\end{array}$ & $50 \%$ & $50 \%$ & $50 \%$ & $38.5 \%$ & $28 \%$ & $28 \%$ \\
\hline Rate on long-term capital gains & $\begin{array}{l}40 \% \text { of individual } \\
\text { rate, } \\
20 \%\end{array}$ & $\begin{array}{l}40 \% \text { of individual } \\
\text { rate, maximum } 20 \%\end{array}$ & $\begin{array}{l}40 \% \text { of individual } \\
\text { rate, } \\
20 \%\end{array}$ & Ordinary rates & Ordinary rates & Ordinary rates \\
\hline Rate on dividends & $=$ individual rates & $=$ individual rates & $=$ individual rates & $=$ individual rates & $=$ individual rates & $=$ individual rates \\
\hline $\begin{array}{l}\text { Limitations on personal exemption and } \\
\text { itemized deductions }\end{array}$ & N.A. & N.A. & N.A. & N.A. & N.A. & N.A. \\
\hline Standard Deduction & $\begin{array}{c}\$ 2,300 \text { (single } \\
\text { person) / } \$ 3,400 \\
\text { (married couple) }\end{array}$ & $\begin{array}{l}\$ 2,400 \text { (single } \\
\text { person) / } \$ 3,550 \\
\text { (married couple) }\end{array}$ & $\begin{array}{c}\$ 2,480 \text { (single } \\
\text { person) / } \$ 3,670 \\
\text { (married couple) }\end{array}$ & $\begin{array}{c}\$ 2,540 \text { (single } \\
\text { person) / } \$ 3,760 \\
\text { (married couple) }\end{array}$ & $\begin{array}{l}\$ 3,000 \text { (single } \\
\text { person) } / \$ 5,000 \\
\text { (married couple) }\end{array}$ & $\begin{array}{c}\$ 3,100 \text { (single person) } \\
/ \$ 5,200 \text { (married } \\
\text { couple) }\end{array}$ \\
\hline AMT exemption $* * * * *$ & $\begin{array}{l}\$ 30,000 \text { for single } \\
\text { filers, } \$ 40,000 \text { for } \\
\text { joint filers }\end{array}$ & $\begin{array}{l}\$ 30,000 \text { for single } \\
\text { filers, } \$ 40,000 \text { for } \\
\text { joint filers }\end{array}$ & $\begin{array}{l}\$ 30,000 \text { for single } \\
\text { filers, } \$ 40,000 \text { for } \\
\text { joint filers }\end{array}$ & $\begin{array}{l}\$ 30,000 \text { for single } \\
\text { filers, } \$ 40,000 \text { for } \\
\text { joint filers }\end{array}$ & $\begin{array}{l}\$ 30,000 \text { for single } \\
\text { filers, } \$ 40,000 \text { for } \\
\text { joint filers }\end{array}$ & $\begin{array}{l}\$ 30,000 \text { for single } \\
\text { filers, } \$ 40,000 \text { for } \\
\text { joint filers }\end{array}$ \\
\hline
\end{tabular}




\begin{tabular}{|c|c|c|c|c|c|c|}
\hline & 1984 & 1985 & 1986 & 1987 & 1988 & 1989 \\
\hline \multicolumn{7}{|l|}{ Taxcredits } \\
\hline Child tax credit & N.A. & N.A. & N.A. & N.A. & N.A. & N.A. \\
\hline $\begin{array}{l}\text { Child and dependent care tax credit (non- } \\
\text { refundable)***** }\end{array}$ & $\begin{array}{l}\text { Maximum } \\
\text { expenditure eligible } \\
\text { for credit is } \$ 2,400 \\
\text { for one child, } \\
\$ 4,800 \text { for two or } \\
\text { more; maximimum } \\
\text { credit is } 20 \%-30 \% \\
\text { of expenditures }\end{array}$ & $\begin{array}{l}\text { Maximum } \\
\text { expenditure eligible } \\
\text { for credit is } \$ 2,400 \\
\text { for one child, } \\
\$ 4,800 \text { for two or } \\
\text { more; maximimum } \\
\text { credit is } 20 \%-30 \% \\
\text { of expenditures }\end{array}$ & $\begin{array}{l}\text { Maximum } \\
\text { expenditure eligible } \\
\text { for credit is } \$ 2,400 \\
\text { for one child, } \\
\$ 4,800 \text { for two or } \\
\text { more; maximimum } \\
\text { credit is } 20 \%-30 \% \\
\text { of expenditures }\end{array}$ & $\begin{array}{l}\text { Maximum } \\
\text { expenditure eligible } \\
\text { for credit is } \$ 2,400 \\
\text { for one child, } \\
\$ 4,800 \text { for two or } \\
\text { more; maximimum } \\
\text { credit is } 20 \%-30 \% \\
\text { of expenditures }\end{array}$ & $\begin{array}{l}\text { Maximum } \\
\text { expenditure eligible } \\
\text { for credit is } \$ 2,400 \\
\text { for one child, } \\
\$ 4,800 \text { for two or } \\
\text { more; maximimum } \\
\text { credit is } 20 \%-30 \% \\
\text { of expenditures }\end{array}$ & $\begin{array}{l}\text { Maximum expenditure } \\
\text { eligible for credit is } \\
\$ 2,400 \text { for one child, } \\
\$ 4,800 \text { for two or } \\
\text { more; maximimum } \\
\text { credit is } 20 \%-30 \% \text { of } \\
\text { expenditures }\end{array}$ \\
\hline EITC rate and maximum credit & $10 \%, \max . \$ 500$ & $11 \%, \max . \$ 550$ & $11 \%, \max . \$ 550$ & $\begin{array}{l}14 \% \text {, max. } \$ 851 \text {, } \\
\text { indexed for inflation }\end{array}$ & $14 \%$, max. $\$ 874$ & $14 \%, \max . \$ 910$ \\
\hline EITC phaseout range and rate & $\begin{array}{l}\$ 6,000-\$ 10,000 \\
12.5 \%\end{array}$ & $\begin{array}{l}\$ 6,500-\$ 11,000, \\
12.22 \%\end{array}$ & $\begin{array}{l}\$ 6,500-\$ 11,000, \\
12.22 \%\end{array}$ & $\begin{array}{l}\$ 6,920-\$ 15,432 \text {, } \\
\text { indexed for } \\
\text { inflation, } 10 \%\end{array}$ & $\begin{array}{l}\$ 9,840-\$ 18,576, \\
10 \%\end{array}$ & $\begin{array}{l}\$ 10,240-\$ 19,340, \\
10 \%\end{array}$ \\
\hline \multicolumn{7}{|l|}{ Social Security $[a]$} \\
\hline Social Security tax rate (OASDI) $[\mathrm{b}]$ & $11.4 \%$ & $11.4 \%$ & $11.4 \%$ & $11.4 \%$ & $12.12 \%$ & $12.12 \%$ \\
\hline Hospital Insurance tax rate $(\mathrm{HI})[\mathrm{c}]$ & $2.6 \%$ & $2.7 \%$ & $2.9 \%$ & $2.9 \%$ & $2.9 \%$ & $2.9 \%$ \\
\hline OASDI taxable maximum earnings & 37,800 & 39,600 & 42,000 & 43,800 & 45,000 & 48,000 \\
\hline HI taxable maximum earnings [d] & 37,800 & 39,600 & 42,000 & 43,800 & 45,000 & 48,000 \\
\hline
\end{tabular}

\begin{tabular}{|c|c|c|c|c|c|c|}
\hline & 1990 & 1991 & 1992 & 1993 & 1994 & 1995 \\
\hline \multicolumn{7}{|l|}{ Income Tax } \\
\hline Number of tax brackets* & 4 & 3 & 3 & 5 & 5 & 5 \\
\hline Lowest individual income tax rate** & $15 \%$ & $15 \%$ & $15 \%$ & $15 \%$ & $15 \%$ & $15 \%$ \\
\hline $\begin{array}{l}\text { Lowest individual income single tax } \\
\text { bracket }\end{array}$ & $\$ 0-\$ 19,450$ & $\$ 0-\$ 20,350$ & $\$ 0-\$ 21,450$ & $\$ 0-\$ 22,100$ & $\$ 0-\$ 22,750$ & $\$ 0-\$ 23,350$ \\
\hline $\begin{array}{l}\text { Lowest individual income joint tax } \\
\text { bracket }\end{array}$ & $\$ 0-\$ 32,450$ & $\$ 0-\$ 34,000$ & $\$ 0-\$ 35,800$ & $\$ 0-\$ 36,900$ & $\$ 0-\$ 38,000$ & $\$ 0-\$ 39,999$ \\
\hline $\begin{array}{l}\text { Other individual income tax brackets } \\
\text { (percent)*,*** }\end{array}$ & 28,33 & 28 & 28 & $28,31,36$ & $28,31,36$ & $28,31,36$ \\
\hline $\begin{array}{l}\text { Highest individual income tax bracket } \\
\text { rate }\end{array}$ & $28 \%$ & $31 \%$ & $31 \%$ & $39.6 \%$ & $39.6 \%$ & $39.6 \%$ \\
\hline $\begin{array}{l}\text { Rate on long-term capital gains } \\
\text { Rate on dividends }\end{array}$ & $\begin{array}{l}28 \% \text { and } 15 \% \\
=\text { individual rates }\end{array}$ & $\begin{array}{l}28 \% \text { and } 15 \% \\
=\text { individual rates }\end{array}$ & $\begin{array}{l}28 \% \text { and } 15 \% \\
=\text { individual rates }\end{array}$ & $\begin{array}{l}28 \% \text { and } 15 \% \\
=\text { individual rates }\end{array}$ & $\begin{array}{l}28 \% \text { and } 15 \% \\
=\text { individual rates }\end{array}$ & $\begin{array}{l}28 \% \text { and } 15 \% \\
=\text { individual rates }\end{array}$ \\
\hline $\begin{array}{l}\text { Limitations on personal exemption and } \\
\text { itemized deductions }\end{array}$ & N.A. & $\begin{array}{l}\text { Personal exemption phases } \\
\text { out (PEP) between } \\
\$ 100,000 \text { and } \$ 222,500 \\
\text { (single), } \$ 150,000 \text { and } \\
\$ 272,500 \text { (joint). Limitation } \\
\text { on itemized deductions } \\
\text { (Pease) for AGI over } \\
\$ 100,000 \text {. Thresholds } \\
\text { indexed for inflation }\end{array}$ & $\begin{array}{l}\text { PEP and Pease, } \\
\text { thresholds indexed } \\
\text { for inflation }\end{array}$ & $\begin{array}{l}\text { PEP and Pease, } \\
\text { thresholds indexed } \\
\text { for inflation }\end{array}$ & $\begin{array}{l}\text { PEP and Pease, } \\
\text { thresholds indexed for } \\
\text { inflation }\end{array}$ & $\begin{array}{l}\text { PEP and Pease, } \\
\text { thresholds indexed } \\
\text { for inflation }\end{array}$ \\
\hline Standard Deduction & $\begin{array}{c}\$ 3,250 \text { (single } \\
\text { person) / } \$ 5,450 \\
\text { (married couple) }\end{array}$ & $\begin{array}{l}\$ 3,400 \text { (single person) / } \\
\$ 5,700 \text { (married couple) }\end{array}$ & $\begin{array}{c}\$ 3,600 \text { (single } \\
\text { person) / } \$ 6,000 \\
\text { (married couple) }\end{array}$ & $\begin{array}{l}\$ 3,700 \text { (single } \\
\text { person) / } \$ 6,200 \\
\text { (married couple) }\end{array}$ & $\begin{array}{c}\$ 3,800 \text { (single person) } \\
/ \$ 6,550 \text { (married } \\
\text { couple) }\end{array}$ & $\begin{array}{c}\$ 3,900 \text { (single } \\
\text { person) / } \$ 6,550 \\
\text { (married couple) }\end{array}$ \\
\hline AMT exemption***** & $\begin{array}{l}\$ 30,000 \text { for single } \\
\text { filers, } \$ 40,000 \text { for } \\
\text { joint filers }\end{array}$ & $\begin{array}{l}\$ 30,000 \text { for single filers, } \\
\$ 40,000 \text { for joint filers }\end{array}$ & $\begin{array}{l}\$ 30,000 \text { for single } \\
\text { filers, } \$ 40,000 \text { for } \\
\text { joint filers }\end{array}$ & $\begin{array}{l}\$ 30,000 \text { for single } \\
\text { filers, } \$ 40,000 \text { for } \\
\text { joint filers }\end{array}$ & $\begin{array}{l}\$ 33,750 \text { for single } \\
\text { filers, } \$ 45,000 \text { for } \\
\text { joint filers }\end{array}$ & $\begin{array}{l}\$ 33,750 \text { for single } \\
\text { filers, } \$ 45,000 \text { for } \\
\text { joint filers }\end{array}$ \\
\hline
\end{tabular}




\begin{tabular}{|c|c|c|c|c|c|c|}
\hline & 1990 & 1991 & 1992 & 1993 & 1994 & 1995 \\
\hline \multicolumn{7}{|l|}{ Taxcredits } \\
\hline Child tax credit & N.A. & N.A. & N.A. & N.A. & N.A. & N.A. \\
\hline $\begin{array}{l}\text { Child and dependent care tax credit (non- } \\
\text { refundable)***** }\end{array}$ & $\begin{array}{l}\text { Maximum } \\
\text { expenditure eligible } \\
\text { for credit is } \$ 2,400 \\
\text { for one child, } \$ 4,800 \\
\text { for two or more; } \\
\text { maximimum credit is } \\
20 \%-30 \% \text { of } \\
\text { expenditures }\end{array}$ & $\begin{array}{l}\text { Maximum expenditure } \\
\text { eligible for credit is } \$ 2,400 \\
\text { for one child, } \$ 4,800 \text { for } \\
\text { two or more; maximimum } \\
\text { credit is } 20 \%-30 \% \text { of } \\
\text { expenditures }\end{array}$ & $\begin{array}{l}\text { Maximum } \\
\text { expenditure eligible } \\
\text { for credit is } \$ 2,400 \\
\text { for one child, } \$ 4,800 \\
\text { for two or more; } \\
\text { maximimum credit is } \\
20 \%-30 \% \text { of } \\
\text { expenditures }\end{array}$ & $\begin{array}{l}\text { Maximum } \\
\text { expenditure eligible } \\
\text { for credit is } \$ 2,400 \\
\text { for one child, } \$ 4,800 \\
\text { for two or more; } \\
\text { maximimum credit is } \\
20 \%-30 \% \text { of } \\
\text { expenditures }\end{array}$ & $\begin{array}{l}\text { Maximum expenditure } \\
\text { eligible for credit is } \\
\$ 2,400 \text { for one child, } \\
\$ 4,800 \text { for two or } \\
\text { more; maximimum } \\
\text { credit is } 20 \%-30 \% \text { of } \\
\text { expenditures }\end{array}$ & $\begin{array}{l}\text { Maximum } \\
\text { expenditure eligible } \\
\text { for credit is } \$ 2,400 \\
\text { for one child, } \$ 4,800 \\
\text { for two or more; } \\
\text { maximimum credit is } \\
20 \%-30 \% \text { of } \\
\text { expenditures }\end{array}$ \\
\hline EITC rate and maximum credit & $14 \%, \max . \$ 953$ & $\begin{array}{l}\text { One child: } 16.7 \% \text {, } \\
\text { maximum } \$ 1,192 \text {; two } \\
\text { children: } 17.3 \% \text {, maximum } \\
\$ 1,235\end{array}$ & $\begin{array}{l}\text { One child: } 17.6 \% \text {, } \\
\text { maximum } \$ 1,324 ; \\
\text { two children: } 18.4 \% \text {, } \\
\text { maximum } \$ 1,384\end{array}$ & $\begin{array}{l}\text { One child: } 18.5 \% \text {, } \\
\text { maximum } \$ 1,434 \text {; } \\
\text { two children: } 19.5 \% \text {, } \\
\text { maximum } \$ 1,511\end{array}$ & $\begin{array}{l}\text { No children: } 7.65 \% \text {, } \\
\text { maximum } \$ 306 \text {; one } \\
\text { child: } 26.3 \% \text {, } \\
\text { maximum } \$ 2,038 \text {; two } \\
\text { children: } 30.0 \% \text {, } \\
\text { maximum } \$ 2,528\end{array}$ & $\begin{array}{l}\text { No children: } 7.65 \% \text {, } \\
\text { maximum } \$ 314 \text {; one } \\
\text { child: } 34 \% \text {, } \\
\text { maximum } \$ 2,094 \text {; } \\
\text { two children: } 36 \% \text {, } \\
\text { maximum } \$ 3,110\end{array}$ \\
\hline EITC phaseout range and rate & $\begin{array}{l}\$ 10,730-\$ 20,264, \\
10 \%\end{array}$ & $\begin{array}{l}\text { One child/two children: } \\
\$ 11,250-\$ 21,250 \\
11.93 \% / 12.36 \%\end{array}$ & $\begin{array}{l}\text { One child: } \$ 11,840 \text { - } \\
\$ 22,370 \text {, two } \\
\text { children: } \$ 11,250 \text { - } \\
\$ 21,250 \text {, } \\
12.57 \% / 13.14 \%\end{array}$ & $\begin{array}{l}\text { One child: } \$ 12,200 \text { - } \\
\$ 23,050 \text {, two } \\
\text { children: } \$ 12,200 \text { - } \\
\$ 23,050 \text {, } \\
13.21 \% / 13.93 \%\end{array}$ & $\begin{array}{l}\text { No children: } \$ 5,000 \text { - } \\
\$ 9,000 \text {, one child: } \\
\$ 11,000-\$ 23,755 \text {, two } \\
\text { children: } \$ 11,000- \\
\$ 25,296 \text {, } \\
7.65 \% / 15.98 \% / 17.68 \\
\%\end{array}$ & $\begin{array}{l}\text { No children: } \$ 5,130 \text { - } \\
\$ 9,230 \text {, one child: } \\
\$ 11,290-\$ 24,396 \text {, } \\
\text { two children: } \\
\$ 11,290-\$ 26,673 \text {, } \\
7.65 \% / 15.98 \% / 20.2 \\
2 \%\end{array}$ \\
\hline \multicolumn{7}{|l|}{ Social Security [a] } \\
\hline Social Security tax rate (OASDI) [b] & $12.4 \%$ & $12.4 \%$ & $12.4 \%$ & $12.4 \%$ & $12.4 \%$ & $12.4 \%$ \\
\hline Hospital Insurance tax rate $(\mathrm{HI})[\mathrm{c}]$ & $2.9 \%$ & $2.9 \%$ & $2.9 \%$ & $2.9 \%$ & $2.9 \%$ & $2.9 \%$ \\
\hline OASDI taxable maximum earnings & 51,300 & 53,400 & 55,500 & 57,600 & 60,600 & 61,200 \\
\hline HI taxable maximum earnings [d] & 51,300 & 125,000 & 130,200 & 135,000 & no max. & no max. \\
\hline
\end{tabular}

\begin{tabular}{|c|c|c|c|c|c|c|}
\hline & 1996 & 1997 & 1998 & 1999 & 2000 & 2001 \\
\hline \multicolumn{7}{|l|}{ Income Tax } \\
\hline Number of tax brackets* & 5 & 5 & 5 & 5 & 5 & 5 \\
\hline Lowest individual income tax rate** & $15 \%$ & $15 \%$ & $15 \%$ & $15 \%$ & $15 \%$ & $15 \%$ \\
\hline $\begin{array}{l}\text { Lowest individual income single tax } \\
\text { bracket }\end{array}$ & $\$ 0-\$ 24,000$ & $\$ 0-\$ 24,650$ & $\$ 0-\$ 25,350$ & $\$ 0-\$ 25,750$ & $\$ 0-\$ 26,250$ & $\$ 0-\$ 27,050$ \\
\hline $\begin{array}{l}\text { Lowest individual income joint tax } \\
\text { bracket }\end{array}$ & $\$ 0-\$ 40,100$ & $\$ 0-\$ 41,200$ & $\$ 0-\$ 42,350$ & $\$ 0-\$ 43,050$ & $\$ 0-\$ 43,850$ & $\$ 0-\$ 45,200$ \\
\hline $\begin{array}{l}\text { Other individual income tax brackets } \\
\text { (percent) })^{*} * * * *\end{array}$ & $28,31,36$ & $28,31,36$ & $28,31,36$ & $28,31,36$ & $28,31,36$ & $27.5,30.5,35.5$ \\
\hline $\begin{array}{l}\text { Highest individual income tax bracket } \\
\text { rate }\end{array}$ & $39.6 \%$ & $39.6 \%$ & $39.6 \%$ & $39.6 \%$ & $39.6 \%$ & $39.10 \%$ \\
\hline
\end{tabular}

\begin{tabular}{|c|c|c|c|c|c|c|}
\hline Rate on long-term capital gains & $28 \%$ and $15 \%$ & $\begin{array}{l}10 \% \text { for tax payers in } \\
\text { the } 15 \% \text { bracket or } \\
\text { below, } 20 \% \text { for others }\end{array}$ & $\begin{array}{l}10 \% \text { for tax payers in } \\
\text { the } 15 \% \text { bracket or } \\
\text { below, } 20 \% \text { for others }\end{array}$ & $\begin{array}{l}10 \% \text { for tax payers in } \\
\text { the } 15 \% \text { bracket or } \\
\text { below, } 20 \% \text { for others }\end{array}$ & $\begin{array}{l}10 \% \text { for tax payers in } \\
\text { the } 15 \% \text { bracket or } \\
\text { below, } 20 \% \text { for others }\end{array}$ & $\begin{array}{l}10 \% \text { for tax payers in the } \\
15 \% \text { bracket or below, } \\
20 \% \text { for others }\end{array}$ \\
\hline Rate on dividends & $=$ individual rates & $=$ individual rates & $=$ individual rates & $=$ individual rates & $=$ individual rates & $=$ individual rates \\
\hline $\begin{array}{l}\text { Limitations on personal exemption and } \\
\text { itemized deductions }\end{array}$ & $\begin{array}{l}\text { PEP and Pease, } \\
\text { thresholds indexed for } \\
\text { inflation }\end{array}$ & $\begin{array}{l}\text { PEP and Pease, } \\
\text { thresholds indexed for } \\
\text { inflation }\end{array}$ & $\begin{array}{l}\text { PEP and Pease, } \\
\text { thresholds indexed for } \\
\text { inflation }\end{array}$ & $\begin{array}{l}\text { PEP and Pease, } \\
\text { thresholds indexed for } \\
\text { inflation }\end{array}$ & $\begin{array}{l}\text { PEP and Pease, } \\
\text { thresholds indexed for } \\
\text { inflation }\end{array}$ & $\begin{array}{l}\text { PEP and Pease, } \\
\text { thresholds indexed for } \\
\text { inflation }\end{array}$ \\
\hline Standard Deduction & $\begin{array}{l}\$ 4,000 \text { (single person) / } \\
\$ 6,700 \text { (married couple) }\end{array}$ & $\begin{array}{l}\$ 4,150 \text { (single person) / } \\
\$ 6,900 \text { (married couple) }\end{array}$ & $\begin{array}{l}\$ 4,250 \text { (single person) / } \\
\$ 7,100 \text { (married couple) }\end{array}$ & $\begin{array}{l}\$ 4,300 \text { (single person) / } \\
\$ 7,200 \text { (married couple) }\end{array}$ & $\begin{array}{l}\$ 4,400 \text { (single person) / } \\
\$ 7,350 \text { (married couple) }\end{array}$ & $\begin{array}{l}\$ 4,550 \text { (single person) / } \\
\$ 7,600 \text { (married couple) }\end{array}$ \\
\hline AMT exemption***** & $\begin{array}{l}\$ 33,750 \text { for single filers, } \\
\$ 45,000 \text { for joint filers }\end{array}$ & $\begin{array}{l}\$ 33,750 \text { for single filers, } \\
\$ 45,000 \text { for joint filers }\end{array}$ & $\begin{array}{l}\$ 33,750 \text { for single filers, } \\
\$ 45,000 \text { for joint filers }\end{array}$ & $\begin{array}{c}\$ 33,750 \text { for single filers, } \\
\$ 45,000 \text { for joint filers }\end{array}$ & $\begin{array}{l}\$ 33,750 \text { for single filers, } \\
\$ 45,000 \text { for joint filers }\end{array}$ & $\begin{array}{l}\$ 35,750 \text { for single filers, } \\
\$ 49,000 \text { for joint filers }\end{array}$ \\
\hline
\end{tabular}




\begin{tabular}{|c|c|c|c|c|c|c|}
\hline & 1996 & 1997 & 1998 & 1999 & 2000 & 2001 \\
\hline \multicolumn{7}{|l|}{ Taxcredits } \\
\hline Child tax credit & N.A. & $\$ 500$ (non-refundable) & $\$ 500$ (non-refundable) & $\$ 500$ (non-refundable) & $\$ 500$ (non-refundable) & $\begin{array}{l}600 \$ \text {, refundable up to } \\
10 \% \text { earned income } \\
\text { above } \$ 10,000 \text {, } \\
\text { threshold indexed for } \\
\text { inflation }\end{array}$ \\
\hline $\begin{array}{l}\text { Child and dependent care tax credit } \\
\text { (non-refundable)***** }\end{array}$ & $\begin{array}{l}\text { Maximum expenditure } \\
\text { eligible for credit is } \\
\$ 2,400 \text { for one child, } \\
\$ 4,800 \text { for two or more; } \\
\text { maximimum credit is } \\
20 \%-30 \% \text { of } \\
\text { expenditures }\end{array}$ & $\begin{array}{l}\text { Maximum expenditure } \\
\text { eligible for credit is } \\
\$ 2,400 \text { for one child, } \\
\$ 4,800 \text { for two or more; } \\
\text { maximimum credit is } \\
20 \%-30 \% \text { of } \\
\text { expenditures }\end{array}$ & $\begin{array}{l}\text { Maximum expenditure } \\
\text { eligible for credit is } \\
\$ 2,400 \text { for one child, } \\
\$ 4,800 \text { for two or more; } \\
\text { maximimum credit is } \\
20 \%-30 \% \text { of } \\
\text { expenditures }\end{array}$ & $\begin{array}{l}\text { Maximum expenditure } \\
\text { eligible for credit is } \\
\$ 2,400 \text { for one child, } \\
\$ 4,800 \text { for two or more; } \\
\text { maximimum credit is } \\
20 \%-30 \% \text { of } \\
\text { expenditures }\end{array}$ & $\begin{array}{l}\text { Maximum expenditure } \\
\text { eligible for credit is } \\
\$ 2,400 \text { for one child, } \\
\$ 4,800 \text { for two or more; } \\
\text { maximimum credit is } \\
20 \%-30 \% \text { of } \\
\text { expenditures }\end{array}$ & $\begin{array}{l}\text { Maximum expenditure } \\
\text { eligible for credit is } \\
\$ 2,400 \text { for one child, } \\
\$ 4,800 \text { for two or more; } \\
\text { maximimum credit is } \\
20 \%-30 \% \text { of } \\
\text { expenditures }\end{array}$ \\
\hline EITC rate and maximum credit & $\begin{array}{l}\text { No children: } 7.65 \% \text {, } \\
\text { maximum } \$ 323 \text {; one } \\
\text { child: } 34 \% \text {, maximum } \\
\$ 2,152 \text {; two children: } \\
40 \% \text {, maximum } \$ 3,556\end{array}$ & $\begin{array}{l}\text { No children: } 7.65 \% \text {, } \\
\text { maximum } \$ 332 \text {; one } \\
\text { child: } 34 \% \text {, maximum } \\
\$ 2,210 \text {; two children: } \\
40 \% \text {, maximum } \$ 3,656\end{array}$ & $\begin{array}{l}\text { No children: } 7.65 \% \text {, } \\
\text { maximum } \$ 341 \text {; one } \\
\text { child: } 34 \% \text {, maximum } \\
\$ 2,271 \text {; two children: } \\
40 \% \text {, maximum } \$ 3,756\end{array}$ & $\begin{array}{l}\text { No children: } 7.65 \% \text {, } \\
\text { maximum } \$ 347 \text {; one } \\
\text { child: } 34 \% \text {, maximum } \\
\$ 2,312 \text {; two children: } \\
40 \% \text {, maximum } \$ 3,816\end{array}$ & $\begin{array}{l}\text { No children: } 7.65 \% \text {, } \\
\text { maximum } \$ 353 \text {; one } \\
\text { child: } 34 \% \text {, maximum } \\
\$ 2,353 \text {; two children: } \\
40 \% \text {, maximum } \$ 3,888\end{array}$ & $\begin{array}{l}\text { No children: } 7.65 \% \text {, } \\
\text { maximum } \$ 364 \text {; one } \\
\text { child: } 34 \% \text {, maximum } \\
\$ 2,428 \text {; two children: } \\
40 \% \text {, maximum } \$ 4,008\end{array}$ \\
\hline EITC phaseout range and rate & $\begin{array}{l}\text { No children: } \$ 5,280- \\
\$ 9,500 \text {, one child: } \\
\$ 11,610-\$ 25,078 \text {, two } \\
\text { children: } \$ 11,610- \\
\$ 28,495 \text {, } \\
7.65 \% / 15.98 \% / 21.06 \\
\%\end{array}$ & $\begin{array}{l}\text { No children: } \$ 5,430- \\
\$ 9,770 \text {, one child: } \\
\$ 11,930-\$ 25,650 \text {, two } \\
\text { children: } \$ 11,930- \\
\$ 29,290 \text {, } \\
7.65 \% / 15.98 \% / 21.06 \%\end{array}$ & $\begin{array}{l}\text { No children: } \$ 5,570- \\
\$ 10,030 \text {, one child: } \\
\$ 12,260-\$ 26,473 \text {, two } \\
\text { children: } \$ 12,260- \\
\$ 30,095 \text {, } \\
7.65 \% / 15.98 \% / 21.06 \%\end{array}$ & $\begin{array}{l}\text { No children: } \$ 5,670- \\
\$ 10,200 \text {, one child: } \\
\$ 12,460-\$ 26,928 \text {, two } \\
\text { children: } \$ 12,460- \\
\$ 30,580 \text {, } \\
7.65 \% / 15.98 \% / 21.06 \\
\%\end{array}$ & $\begin{array}{l}\text { No children: } \$ 5,770 \text { - } \\
\$ 10,380 \text {, one child: } \\
\$ 12,690-\$ 27,413 \text {, two } \\
\text { children: } \$ 12,690 \text { - } \\
\$ 31,152 \text {, } \\
7.65 \% / 15.98 \% / 21.06 \\
\%\end{array}$ & $\begin{array}{l}\text { No children: } \$ 5,950- \\
\$ 10,710 \text {, one child: } \\
\$ 13,090-\$ 28,281 \text {, two } \\
\text { children: } \$ 13,090- \\
\$ 32,121 \text {, } \\
7.65 \% / 15.98 \% / 21.06 \%\end{array}$ \\
\hline \multicolumn{7}{|l|}{ Social Sec urity $[a]$} \\
\hline Social Security tax rate (OASDI) [b] & $12.4 \%$ & $12.4 \%$ & $12.4 \%$ & $12.4 \%$ & $12.4 \%$ & $12.4 \%$ \\
\hline Hospital Insurance tax rate $(\mathrm{HI})[\mathrm{c}]$ & $2.9 \%$ & $2.9 \%$ & $2.9 \%$ & $2.9 \%$ & $2.9 \%$ & $2.9 \%$ \\
\hline OASDI taxable maximum earnings & 62,700 & 65,400 & 68,400 & 72,600 & 76,200 & 80,400 \\
\hline HI taxable maximum earnings [d] & no max. & no $\max$. & no max. & no max. & no max. & no max. \\
\hline
\end{tabular}

\begin{tabular}{|c|c|c|c|c|c|c|}
\hline & 2002 & 2003 & 2004 & 2005 & 2006 & 2007 \\
\hline \multicolumn{7}{|l|}{ Income Tax } \\
\hline Number of tax brackets* & 6 & 6 & 6 & 6 & 6 & 6 \\
\hline Lowest individual income tax rate** & $10 \%$ & $10 \%$ & $10 \%$ & $10 \%$ & $10 \%$ & $10 \%$ \\
\hline $\begin{array}{l}\text { Lowest individual income single tax } \\
\text { bracket }\end{array}$ & $\$ 0-\$ 6,000$ & $\$ 0-\$ 7,000$ & $\$ 0-\$ 7,150$ & $\$ 0-\$ 7,300$ & $\$ 0-\$ 7,550$ & $\$ 0-\$ 7,825$ \\
\hline $\begin{array}{l}\text { Lowest individual income joint tax } \\
\text { bracket }\end{array}$ & $\$ 0-\$ 12,000$ & $\$ 0-\$ 14,000$ & $\$ 0-\$ 14,300$ & $\$ 0-\$ 14,600$ & $\$ 0-\$ 15,100$ & $\$ 0-\$ 15,650$ \\
\hline $\begin{array}{l}\text { Other individual income tax brackets } \\
\text { (percent)*, **** }\end{array}$ & $15,27,30,35$ & $15,25,28,33$ & $15,25,28,33$ & $15,25,28,33$ & $15,25,28,33$ & $15,25,28,33$ \\
\hline $\begin{array}{l}\text { Highest individual income tax bracket } \\
\text { rate }\end{array}$ & $38.6 \%$ & $35 \%$ & $35 \%$ & $35 \%$ & $35 \%$ & $35 \%$ \\
\hline Rate on long-term capital gains & $\begin{array}{l}10 \% \text { for tax payers in } \\
\text { the } 15 \% \text { bracket or } 1 \\
\text { below, } 20 \% \text { for others }\end{array}$ & $\begin{array}{l}5 \% \text { for taxpayers in the } \\
15 \% \text { bracket; } 15 \% \text { for } \\
\text { other brackets }\end{array}$ & $\begin{array}{l}5 \% \text { for taxpayers in the } \\
15 \% \text { bracket; } 15 \% \text { for } \\
\text { other brackets }\end{array}$ & $\begin{array}{l}5 \% \text { for taxpayers in the } \\
15 \% \text { bracket; } 15 \% \text { for } \\
\text { other brackets }\end{array}$ & $\begin{array}{l}5 \% \text { for taxpayers in the } 5 \% \\
15 \% \text { bracket; } 15 \% \text { for the } \\
\text { other brackets }\end{array}$ & $\begin{array}{l}5 \% \text { for taxpayers in } \\
\text { he } 15 \% \text { bracket; } \\
15 \% \text { for other }\end{array}$ \\
\hline Rate on dividends & $=$ individual rates & $\begin{array}{l}5 \% \text { for taxpayers in the } \\
15 \% \text { bracket; } 15 \% \text { for } \\
\text { other brackets }\end{array}$ & $\begin{array}{l}5 \% \text { for taxpayers in the } \\
15 \% \text { bracket; } 15 \% \text { for } \\
\text { other brackets }\end{array}$ & $\begin{array}{l}5 \% \text { for taxpayers in the } \\
15 \% \text { bracket; } 15 \% \text { for } \\
\text { other brackets }\end{array}$ & $\begin{array}{l}5 \% \text { for taxpayers in the } 5 \% \\
15 \% \text { bracket; } 15 \% \text { for the } \\
\text { other brackets }\end{array}$ & $\begin{array}{l}\text {. for taxpayers in } \\
\text { he } 15 \% \text { bracket; } \\
15 \% \text { for other }\end{array}$ \\
\hline $\begin{array}{l}\text { Limitations on personal exemption and } \\
\text { itemized deductions }\end{array}$ & $\begin{array}{l}\text { PEP and Pease, } \\
\text { thresholds indexed for } \\
\text { inflation }\end{array}$ & $\begin{array}{l}\text { PEP and Pease, } \\
\text { thresholds indexed for } \\
\text { inflation }\end{array}$ & $\begin{array}{l}\text { PEP and Pease, } \\
\text { thresholds indexed for } \\
\text { inflation }\end{array}$ & $\begin{array}{l}\text { PEP and Pease, } \\
\text { thresholds indexed for } \\
\text { inflation }\end{array}$ & $\begin{array}{ll}\text { PEP and Pease limits on } & \mathrm{PE} \\
\text { personal exemptions and } & \text { on } \\
\text { itemized deductions } & \text { ex } \\
\text { reduced by } 1 / 3, & \text { ite } \\
\text { thresholds indexed for } & \text { th } \\
\text { inflation } & \text { for }\end{array}$ & $\begin{array}{l}\text { PEP and Pease limits } \\
\text { on personal } \\
\text { exemptions and } \\
\text { temized deductions } \\
\text { educed by } 1 / 3 \text {, } \\
\text { hresholds indexed } \\
\text { cor inflation }\end{array}$ \\
\hline Standard Deduction & $\begin{array}{l}\$ 4,700 \text { (single person) / } \\
\$ 7,850 \text { (married couple) }\end{array}$ & $\begin{array}{l}\$ 4,750 \text { (single person) / } \\
\$ 9,500 \text { (married couple) }\end{array}$ & $\begin{array}{l}\$ 4,850 \text { (single person) / } \\
\$ 9,700 \text { (married couple) }\end{array}$ & $\begin{array}{c}\$ 5,000 \text { (single person) } / \\
\$ 10,000 \text { (married } \\
\text { couple) }\end{array}$ & $\begin{array}{c}\$ 5,150 \text { (single person) / } \\
\$ 10,300 \text { (married } \\
\text { couple) }\end{array}$ & $\begin{array}{c}\$ 5,350 \text { (single } \\
\text { person) / } \$ 10,700 \\
\text { (married couple) }\end{array}$ \\
\hline AMT exemption $* * * * *$ & $\begin{array}{l}\$ 35,750 \text { for single filers, } \\
\$ 49,000 \text { for joint filers }\end{array}$ & $\begin{array}{l}\$ 40,250 \text { for single filers, } \\
\$ 58,000 \text { for joint filers }\end{array}$ & $\begin{array}{l}\$ 40,250 \text { for single filers, } \\
\$ 58,000 \text { for joint filers }\end{array}$ & $\begin{array}{l}\$ 40,250 \text { for single filers, } \\
\$ 58,000 \text { for joint filers }\end{array}$ & $\begin{array}{l}\$ 42,500 \text { for single filers, } \\
\$ 62,550 \text { for joint filers }\end{array}$ & $\begin{array}{c}\$ 44,350 \text { for single } \\
\text { filers, } \$ 66,250 \text { for } \\
\text { joint filers }\end{array}$ \\
\hline
\end{tabular}




\begin{tabular}{|c|c|c|c|c|c|c|}
\hline & 2002 & 2003 & 2004 & 2005 & 2006 & 2007 \\
\hline \multicolumn{7}{|l|}{ Taxcredits } \\
\hline Child tax credit & $\begin{array}{l}600 \$ \text {, refundable up to } \\
10 \% \text { earned income } \\
\text { above } \$ 10,350\end{array}$ & $\begin{array}{l}1,000 \$ \text {, refundable up to } \\
10 \% \text { earned income } \\
\text { above } \$ 10,500\end{array}$ & $\begin{array}{l}1,000 \$ \text {, refundable up to } \\
15 \% \text { earned income } \\
\text { above } \$ 10,750\end{array}$ & $\begin{array}{l}1,000 \$ \text {, refundable up } \\
\text { to } 15 \% \text { earned income } \\
\text { above } \$ 11,000\end{array}$ & $\begin{array}{l}1,000 \$ \text {, refundable up to } \\
15 \% \text { earned income } \\
\text { above } \$ 11,300\end{array}$ & $\begin{array}{l}1,000 \$ \text {, refundable up } \\
\text { to } 15 \% \text { earned } \\
\text { income above } \\
\$ 11,750\end{array}$ \\
\hline $\begin{array}{l}\text { Child and dependent care tax credit (non- } \\
\text { refundable)***** }\end{array}$ & $\begin{array}{l}\text { Maximum eligible } \\
\text { expenses are } \$ 3,000 \text { for } \\
1 \text { child; } \$ 6,000 \text { for } 2 \text { or } \\
\text { more; maximum credit is } \\
35 \% \text { (phasing down to } \\
20 \% \text { at } \$ 15,000 \text { of AGI) }\end{array}$ & $\begin{array}{l}\text { Maximum eligible } \\
\text { expenses are } \$ 3,000 \text { for } 1 \\
\text { child; } \$ 6,000 \text { for } 2 \text { or } \\
\text { more; maximum credit is } \\
35 \% \text { (phasing down to } \\
20 \% \text { at } \$ 15,000 \text { of AGI) }\end{array}$ & $\begin{array}{l}\text { Maximum eligible } \\
\text { expenses are } \$ 3,000 \text { for } 1 \\
\text { child; } \$ 6,000 \text { for } 2 \text { or } \\
\text { more; maximum credit is } \\
35 \% \text { (phasing down to } \\
20 \% \text { at } \$ 15,000 \text { of AGI) }\end{array}$ & $\begin{array}{l}\text { Maximum eligible } \\
\text { expenses are } \$ 3,000 \text { for } \\
1 \text { child; } \$ 6,000 \text { for } 2 \text { or } \\
\text { more; maximum credit } \\
\text { is } 35 \% \text { (phasing down } \\
\text { to } 20 \% \text { at } \$ 15,000 \text { of } \\
\text { AGI) }\end{array}$ & $\begin{array}{l}\text { Maximum eligible } \\
\text { expenses are } \$ 3,000 \text { for } \\
1 \text { child; } \$ 6,000 \text { for } 2 \text { or } \\
\text { more; maximum credit is } \\
35 \% \text { (phasing down to } \\
20 \% \text { at } \$ 15,000 \text { of AGI) }\end{array}$ & $\begin{array}{l}\text { Maximum eligible } \\
\text { expenses are } \$ 3,000 \\
\text { for } 1 \text { child; } \$ 6,000 \text { for } \\
2 \text { or more; maximum } \\
\text { credit is } 35 \% \\
\text { (phasing down to } \\
20 \% \text { at } \$ 15,000 \text { of } \\
\text { AGI) }\end{array}$ \\
\hline EITC rate and maximum credit & $\begin{array}{l}\text { No children: } 7.65 \% \text {, } \\
\text { maximum } \$ 376 \text {; one } \\
\text { child: } 34 \% \text {, maximum } \\
\$ 2,506 \text {; two children: } \\
40 \% \text {, maximum } \$ 4,140\end{array}$ & $\begin{array}{l}\text { No children: } 7.65 \% \text {, } \\
\text { maximum } \$ 382 \text {; one } \\
\text { child: } 34 \% \text {, maximum } \\
\$ 2,547 \text {; two children: } \\
40 \% \text {, maximum } \$ 4,204\end{array}$ & $\begin{array}{l}\text { No children: } 7.65 \% \text {, } \\
\text { maximum } \$ 390 \text {; one } \\
\text { child: } 34 \% \text {, maximum } \\
\$ 2,604 \text {; two children: } \\
40 \% \text {, maximum } \$ 4,300\end{array}$ & $\begin{array}{l}\text { No children: } 7.65 \% \text {, } \\
\text { maximum } \$ 399 \text {; one } \\
\text { child: } 34 \% \text {, maximum } \\
\$ 2,662 \text {; two children: } \\
40 \% \text {, maximum } \$ 4,400\end{array}$ & $\begin{array}{l}\text { No children: } 7.65 \%, \\
\text { maximum } \$ 412 \text {; one } \\
\text { child: } 34 \% \text {, maximum } \\
\$ 2,747 \text {; two children: } \\
40 \% \text {, maximum } \$ 4,536\end{array}$ & $\begin{array}{l}\text { No children: } 7.65 \% \text {, } \\
\text { maximum } \$ 428 \text {; one } \\
\text { child: } 34 \% \text {, maximum } \\
\$ 2,853 \text {; two children: } \\
40 \% \text {, maximum } \\
\$ 4,716\end{array}$ \\
\hline EITC phaseout range and rate & $\begin{array}{l}\text { No children: } \$ 6,150- \\
\$ 11,060 \text {, one child: } \\
\$ 13,520-\$ 29,201 \text {, two } \\
\text { children: } \$ 13,520- \\
\$ 33,178 \text {. } \\
\text { Starting/ending points } \\
\text { increased by } \$ 1,000 \text { for } \\
\text { joint filers. } \\
7.65 \% / 15.98 \% / 21.06 \%\end{array}$ & $\begin{array}{l}\text { No children: } \$ 6,240- \\
\$ 11,230 \text {, one child: } \\
\$ 13,730-\$ 29,666 \text {, two } \\
\text { children: } \$ 13,730- \\
\$ 33,692 \text {. Increased by } \\
\$ 1,000 \text { for joint filers. } \\
7.65 \% / 15.98 \% / 21.06 \%\end{array}$ & $\begin{array}{l}\text { No children: } \$ 6,390- \\
\$ 11,490 \text {, one child: } \\
\$ 14,040-\$ 30,338 \text {, two } \\
\text { children: } \$ 14,040- \\
\$ 34,458 \text {. Increased by } \\
\$ 1,000 \text { for joint filers. } \\
7.65 \% / 15.98 \% / 21.06 \%\end{array}$ & $\begin{array}{l}\text { No children: } \$ 6,530- \\
\$ 11,750 \text {, one child: } \\
\$ 14,370-\$ 31,030 \text {, two } \\
\text { children: } \$ 14,370- \\
\$ 35,263 \text {. Increased by } \\
\$ 2,000 \text { for joint filers. } \\
7.65 \% / 15.98 \% / 21.06 \\
\%\end{array}$ & $\begin{array}{l}\text { No children: } \$ 6,740- \\
\$ 12,120 \text {, one child: } \\
\$ 14,810-\$ 32,001 \text {, two } \\
\text { children: } \$ 14,810- \\
\$ 36,348 \text {. Increased by } \\
\$ 2,000 \text { for joint filers. } \\
7.65 \% / 15.98 \% / 21.06 \%\end{array}$ & $\begin{array}{l}\text { No children: } \$ 7,000- \\
\$ 12,590 \text {, one child: } \\
\$ 15,390-\$ 33,241 \text {, } \\
\text { two children: } \$ 15,390 \text { - } \\
\$ 37,783 \text {. Increased by } \\
\$ 2,000 \text { for joint filers. } \\
7.65 \% / 15.98 \% \text { / } \\
21.06 \%\end{array}$ \\
\hline \multicolumn{7}{|l|}{ Social Security [a] } \\
\hline Social Security tax rate (OASDI) [b] & $12.4 \%$ & $12.4 \%$ & $12.4 \%$ & $12.4 \%$ & $12.4 \%$ & $12.4 \%$ \\
\hline Hospital Insurance tax rate $(\mathrm{HI})[\mathrm{c}]$ & $2.9 \%$ & $2.9 \%$ & $2.9 \%$ & $2.9 \%$ & $2.9 \%$ & $2.9 \%$ \\
\hline OASDI taxable maximum earnings & 84,900 & 87,000 & 87,900 & 90,000 & 94,200 & 97,500 \\
\hline HI taxable maximum earnings [d] & no $\max$. & no max. & no max. & no max. & no $\max$. & no max. \\
\hline
\end{tabular}




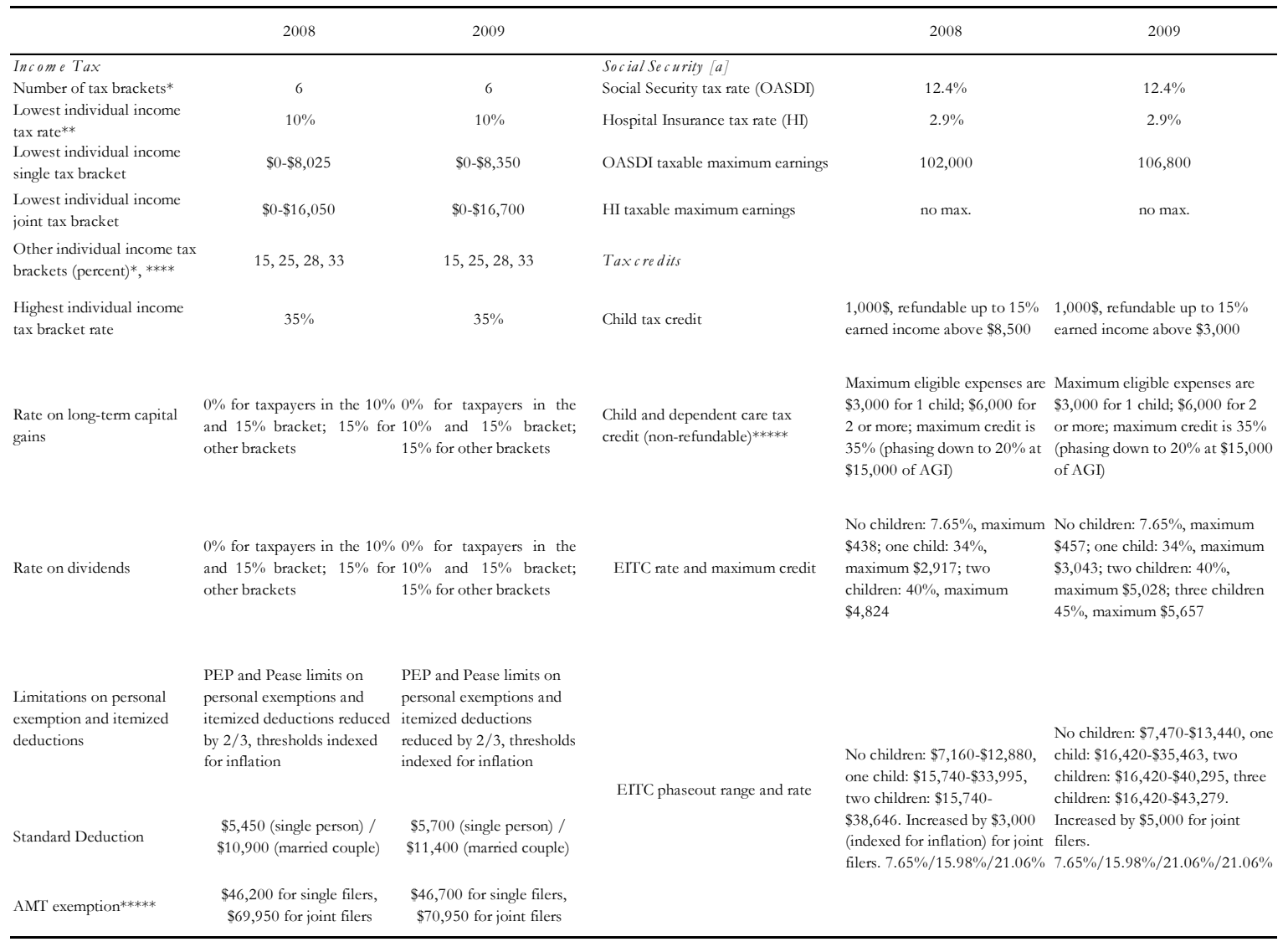

Notes:

* Married couple filing jointly

** Indexing of income brackets for individual income tax began in 1985 under ERTA81 except for 1987 and 1988 when brackets were not indexed because of rate changes; Changes in bracket amounts for 1985-1986, 1989-2000, and 2004-2007 occured as a result of indexing for inflation rather than from a change in tax legislation *** $0 \%$ rate existed below these brackets until 1986

**** For years 1988-1990 rate applicable to highest income bracket is not the highest rate: $28 \%$ rate is applicable to two income brackets - the highest bracket and a lower one ***** Not indexed for inflation

[a] The taxable maximum for 1979-81 was set by statute; all other amounts were determined under automatic adjustment provisions of the Social Security Act according to the national average wage index. The tax rate refers to the combined rate for employers and employees.

[b] OASDI: Old-Age, Survivors, and Disability Insurance program

[c] HI: Medicare's Hospital Insurance program

[d] The upper limit on earnings subject to HI was repealed by the Omnibus Budget Reconciliation Act of 1993.

Sources: Tax Policy Center (http://www.taxpolicycenter.org/taxfacts/index.cfm), Social Security Administration (http://www.ssa.gov/OACT/COLA/cbb.htm and http://www.ssa.gov/OACT/ProgData/taxRates.html), last accessed May 2011 